\title{
URBAN POLICY AND HERITAGE PLANNING:THE DISPROPORTIONATE DESIGNATION OF HERITAGE CONSERVATION DISTRICTS (HCDs) IN THE CITY OF TORONTO
}

by

\author{
Chante Barnwell \\ Honours Bachelor of Arts, \\ University of Toronto, 2014 \\ Master of Fine Arts in Documentary Media, \\ Ryerson University, 2018
}

\author{
A MRP \\ presented to Ryerson University \\ in partial fulfillment of the \\ requirements for the degree of \\ Master of Arts \\ in the program of \\ Public Policy and Administration
}

Toronto, Ontario, Canada, 2020

(C) Chante Barnwell, 2020 


\section{AUTHOR'S DECLARATION FOR ELECTRONIC SUBMISSION OF A MRP}

I hereby declare that I am the sole author of this MRP. This is a true copy of the MRP, including any required final revisions.

I authorize Ryerson University to lend this MRP to other institutions or individuals for the purpose of scholarly research.

I further authorize Ryerson University to reproduce this MRP by photocopying or by other means, in total or in part, at the request of other institutions or individuals for the purpose of scholarly research.

I understand that my MRP may be made electronically available to the public. 


\title{
URBAN POLICY AND HERITAGE PLANNING:THE DISPROPORTIONATEDESIGNATION OF HERITAGE CONSERVATION DISTRICTS (HCDs) IN THE CITY OF TORONTO
}

(C) Chante Barnwell, 2020

Master of Arts

in

Public Policy and Administration

Ryerson University

\begin{abstract}
This Major Research Paper (MRP) examines the disproportionate designation of Heritage Conservation Districts (HCDs) within the City of Toronto, which are predominantly located in the City's downtown core, compared to the City's inner suburban areas. To illustrate the discrepancies in HCD designation, two potential HCDs in Scarborough, one of three inner suburbs in Toronto, are chronologically examined. Both Agincourt and Midland Park's HCD represent the most recent examples of heritage designation in the inner suburb, which stands as the only area in the City that has zero HCDs. Before the case studies are discussed, the effects of Toronto's 1998 amalgamation, select timeframes of the City's planning history and recent changes to Provincial planning legislation that govern municipalities' heritage approach are examined. It is determined that a series of factors contribute to the disproportionate designation of HCDs in the City of Toronto. These factors include the incremental designation of heritage properties post amalgamation, the lengthy heritage designation process, the intergovernmental nature of municipal heritage policies, the lack of public education on the benefits of heritage and a complex HCD prioritization process all contribute to the disproportionate designation of HCD's in the City of Toronto. Four key recommendations are offered to help resolve the heritage designation issue in the City of Toronto.
\end{abstract}

Keywords: Heritage Conservation Districts; Toronto; Urban Planning, Urban Policy, Heritage Urbanism. 


\section{ACKNOWLEDGMENTS}

First and foremost, I have to thank God for keeping me safe during this pandemic. It's my faith that has kept me throughout this journey, from the start of the MPPA program in Fall 2019 to the end of the program in 2020. By God's grace, I completed all my courses and this Major Research Paper (MRP). I served as an elected graduate student representative on the MPPA program council/executive committee, and I also received the St. George's Society of Toronto/Bill Davis MPPA Graduate Entrance award for my academic excellence and extensive community volunteer contributions. Overall, in these unprecedented times, I am pleased to be obtaining my Master's degree in the Public Policy and Administration program at Ryerson University.

To my supervisor, Dr. Duncan MacLellan and my second reader Dr. Anver Saloojee, thank you for your steadfast commitment to my Major Research Paper (MRP), your timely feedback, and your acknowledgement of my research, it was greatly appreciated.

To my Mother, Mrs. Faye W. Barnwell, thank you for your unfailing love, dedication and support throughout my academic journey. As I wrote and conducted research for this MRP through the global pandemic of COVID-19 and in the heightened injustice of racial inequality, you always had full confidence in me and my vision as a creative social science scholar. You will forever be my frontline hero; this second Master's degree is dedicated to you. 


\section{TABLE OF CONTENTS}

AUTHOR'S DECLARATION FOR ELECTRONIC SUBMISSION OF A MRP ................................ii

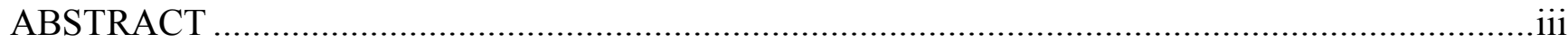

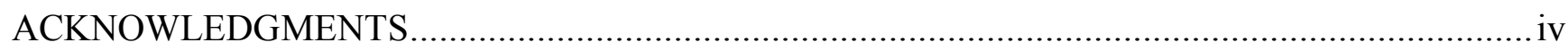

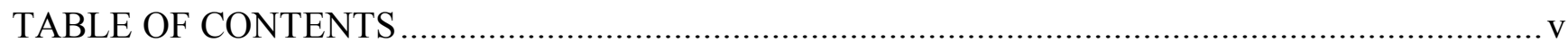

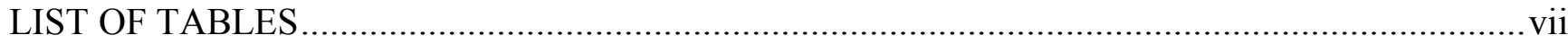

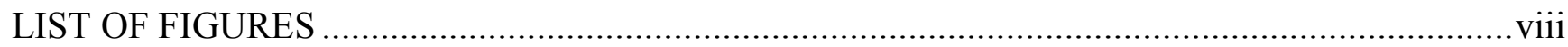

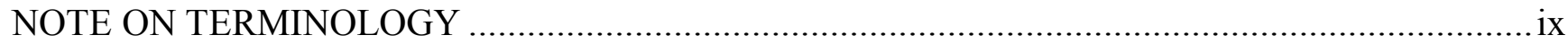

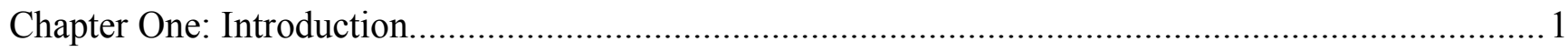

1.1 HCD Regulation in Canada and the Role of Conventions and Charters........................................ 1

1.1.2 Heritage Conservation Districts (HCDs) in the Province of Ontario.........................................

1.1.3 Heritage Toronto and Heritage Conservation Districts (HCDs) in the City of Toronto ..............7

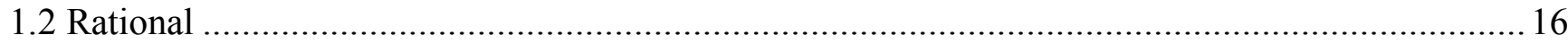

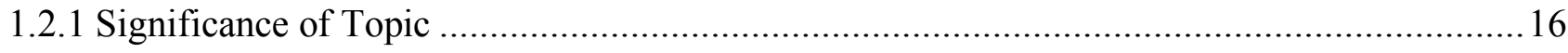

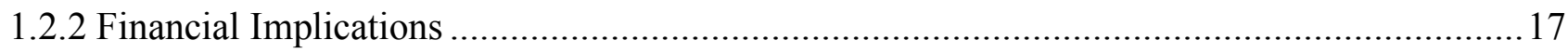

1.2.3 Gap in research on Heritage Conservation Districts (HCDs) .................................................. 19

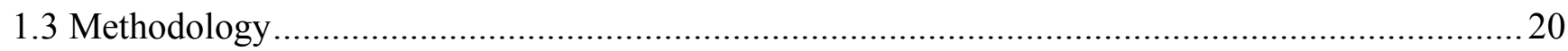

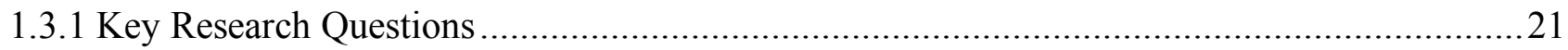

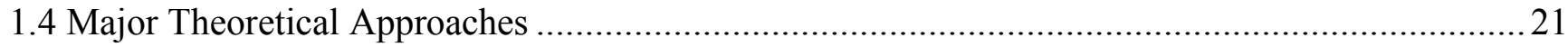

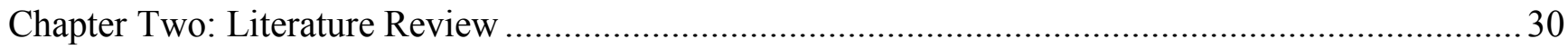

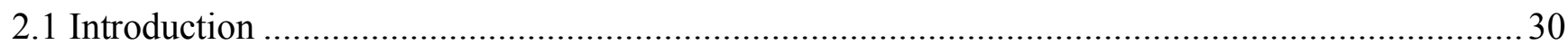

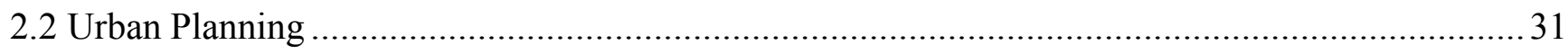

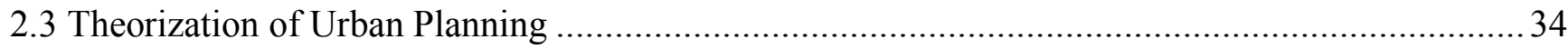

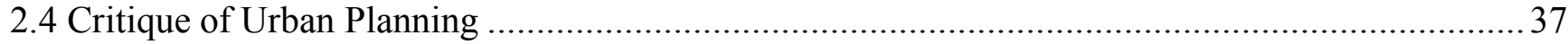

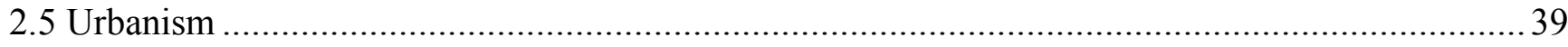

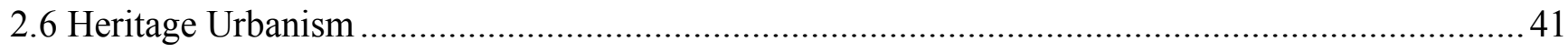

Chapter Three: History of Urban Planning in Toronto and LPAT .................................................. 45

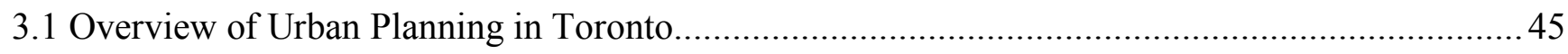

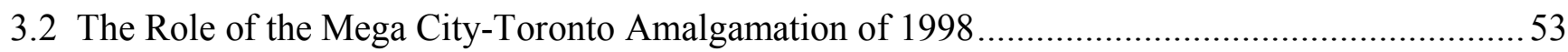

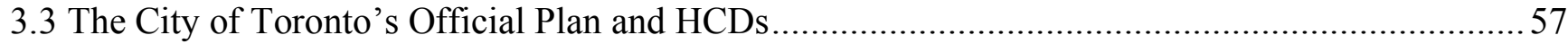

Chapter Four: Provincial Bodies and Legislation-Amendments, Anger and Awakening ......................60

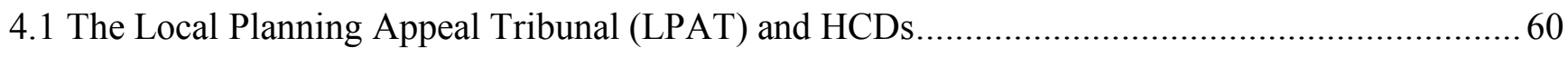


4.2 Provincial Policy Statement (PPS) 2020 and Heritage Conservation......................................6 65

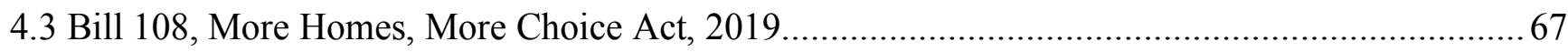

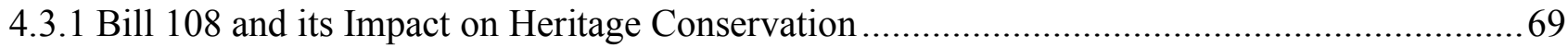

Chapter Five: The Disproportionate Designation of Heritage Conservation Districts in Toronto.........73

5.1 Overview of Pre-existing HCDs and the Notion of the "Ideal District" ....................................73

5.2 Heritage Property Designation and It's Relationship to HCDs ........................................... 76

5.3 HCD Case Study 1\#: Agincourt Heritage Conservation District ...........................................8 82

5.4 HCD Case Study 2\#: Midland Park Heritage Conservation District......................................... 96

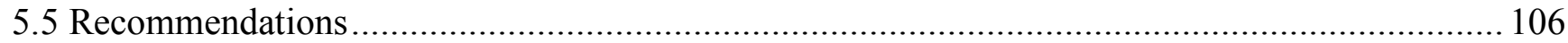

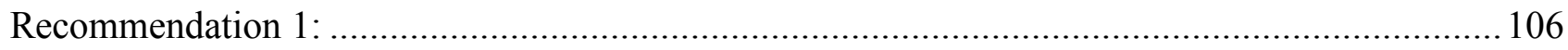

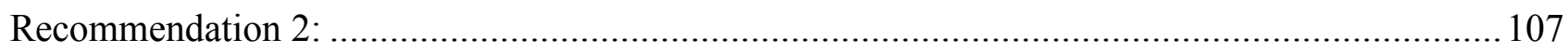

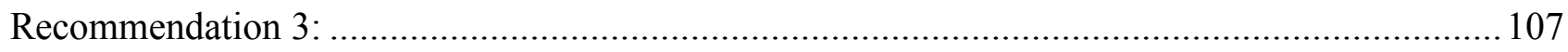

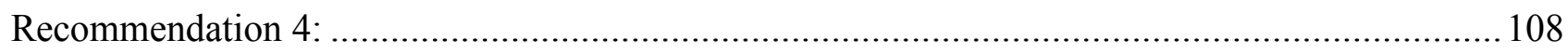

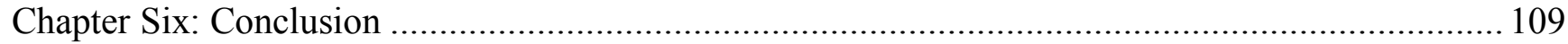

6.0 HCDs in Toronto: Planning, Pause and Potential................................................................... 109

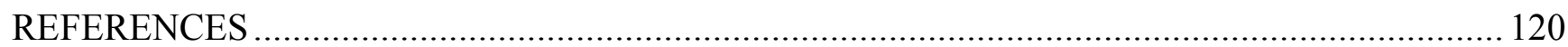




\section{LIST OF TABLES}

Table 1.Heritage Urbanism Methodology................................................. 42

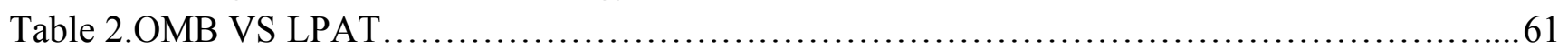

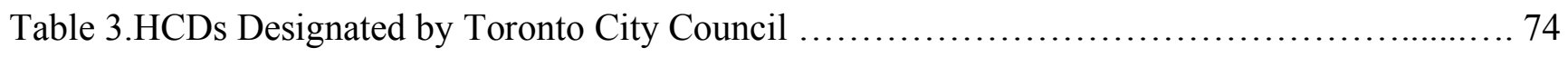

Table 4.Heritage Conservation Districts Under Appeal at The Local Planning Appeal Tribunal

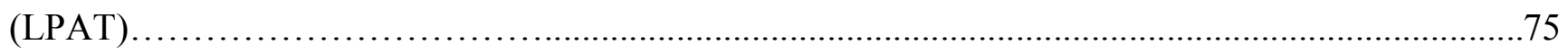

Table 5.Heritage Conservation Districts in Development........................................ 76

Table 6.Heritage Conservation District Studies Prioritization Criteria.............................. 89

Table 7.Table of Outstanding Heritage Conservation District Studies........................... 94

Table 8.Heritage Conservation Districts Case Study Comparison...................................114 


\section{LIST OF FIGURES}

Figure 1.How Heritage Conservation Districts Become a Reality-Flow Chart.......................... 4

Figure 2.Visible Minorities in the Toronto Census Metropolitan Area's (CMA)...................... 27

Figure 3.Heritage Conservation Districts Map..............................................75

Figure 4.Screengrab of the Heritage Register Map........................................... 80

Figure 5.Screengrab of the Heritage Property Search Tool.................................. 80

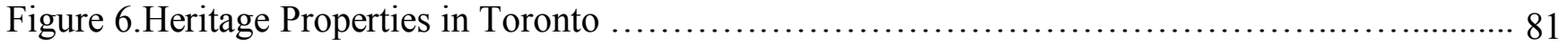

Figure 7.Screengrab of the City of Toronto's Heritage Properties Interactive Heritage Mapping

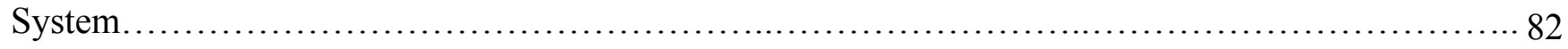

Figure 8.City of Toronto's Attachment 9A HCD Prioritization Map-Agincourt HCD...................... 85

Figure 9.Chart of Prioritization Outcomes in the City of Toronto's Heritage Conservation District

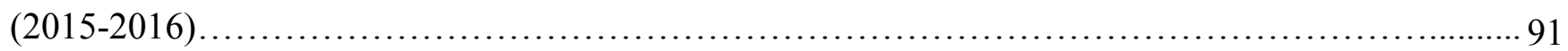

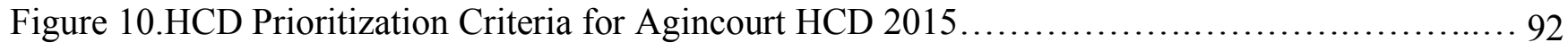

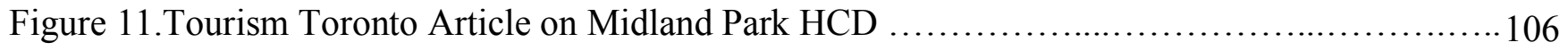

Figure 12.City Wide Heritage Survey Phased Work Plan Chart (2019-2022)..........................111 


\section{NOTE ON TERMINOLOGY}

Various factors contribute to the interchangeability of heritage terms; Kalman notes that "heritage terminology is variable at best, sometimes dictated by national usage sometimes by choice, and sometimes by ignorance"(Kalman, 2014, p. 10). She further suggests that one person's preservation is another's conservation, what some call restoration others may know as renovation"(Kalman, 2014, p. 10). Echoing Kalman, the Canadian Register of Historic Places (CRHP), "a federal, provincial and territorial collaboration designed to conserve historic places in Canada ....and a national, searchable, online database"(Parks Canada, 2006, p. 2), notes that "different Canadian jurisdictions use different terms to identify historic places"(Parks Canada, 2006, p. 36). In Canada, these terms include, “' 'historic area', 'historic district', 'heritage precinct', 'cultural landscape', 'heritage conservation area', 'secteur patrimonial' and 'arrondissement historique'(French)'(Parks Canada, 2006, p. 36).

It is important to note that each municipality uses their own terminology, as they see fit, therefore, "the use of a pan-Canadian term by the CRHP "heritage district" (English) and "secteur patrimonial" (French) does not restrict the continued use of other terms in each jurisdiction"(Parks Canada, 2006, p. 36). The use of appropriate terminology and definitions for urban heritage can be officially sourced from The Standards and Guidelines for Conservation of Historic Places in Canada (Kalman, 2014, p. 11). In addition, provincial heritage documents, municipal heritage policy manuals and official plans are all sources for heritage terminology. This MRP specifically sources terms and definition of HCDs from the Ontario Heritage Tool Kit as well as the City of Toronto's Heritage Conservation Districts in Toronto: Procedures, Policies and Terms Maunel as well as the City of Toronto's Official Plan. At certain points in the MRP, these terms are used interchangeably, and I will point to the discrepancies and clarify them as they arise. 


\section{Chapter One: Introduction}

\subsection{HCD Regulation in Canada and the Role of Conventions and Charters}

Canada's urban heritage is "rooted in the past, but also a dynamic part of the present and future planning decisions (as well as) community growth” (R. Shipley \& Snyder, 2013, p. 304). The "Federal Standards and Guidelines have regulatory control for federal properties only"(City of Toronto, Heritage Preservation Services, 2007, p. 77). Furthermore, "Parks Canada is the primary department that manages heritage, encompassing the Historic Sites and Monuments Board of Canada, the Federal Heritage Buildings Review Office (for federal buildings only) and the Historic Places Initiative” (City of Toronto, Heritage Preservation Services, 2007, p. 77).

Scholars note that the Federal government "signed the World Heritage Convention in 1974, and (this) legislation, ostensibly designed to protect historic resources, was enacted in the Province of Ontario the following year" (Robert Shipley et al., 2011, p. 215). The United Nations Educational, Scientific and Cultural Organization (UNESCO), an "agency responsible for culture" (Kalman, 2014, p. 127), developed the convention. Scholars note that these conventions are largely considered to have created "the dichotomy between two opposing and mutually exclusive worlds of the tangible and intangible (in) culture and heritage, including creating regional and geographical separation between the 'west vs the rest' "'(Kalman, 2014, p. 146). Another crucial organizational body is the "International Council on Monuments and Sites (ICOMOS), a non-governmental organization that operates under the umbrella of UNESCO” (Kalman, 2014, p. 127). These international bodies contribute to heritage conservation guidelines but do not have "regulatory status outside of the international arena" (City of Toronto, Heritage Preservation Services, 2007, p. 77). 
Further, Shipley notes that "the charters and conventions have helped to underpin national and international heritage conservation procedures" (Robert Shipley \& Kovacs, 2008, p. 218). The Athens Charter of 1931, for example, "laid the groundwork for the notion of legislated architectural and cultural conservation"(Robert Shipley et al., 2011, p. 612). While the Venice Charter of 1964, formally the "International Charter for the Conservation and Restoration of Monuments and Sites defines historic monuments, albeit primarily ancient ones, and sets out some basic guidelines over their conservation and restoration" (Robert Shipley \& Kovacs, 2005, p. 10). Alongside these long-standing conventions and charters, planning policy shapes heritage conservation practices in the Province of Ontario. In the next section, the relationship between HCDs and provincial policy will be addressed.

\subsubsection{Heritage Conservation Districts (HCDs) in the Province of Ontario}

The responsibility for heritage conservation is regulated under the Ministry of Heritage, Sport, Tourism and Culture Industries and the Ministry of Municipal Affairs and Housing. In addition, in 1974, the:

Ontario Heritage Foundation (now the Ontario Heritage Trust) was established as an arm's length agency of the provincial government to identify, protect, renew, and promote 'Ontario's rich and diverse built, cultural and natural heritage' . . for the benefit of present and future generations. (Relph, 2014, p. 153)

While the Ministry of Heritage, Sport, Tourism and Culture Industries is responsible for issuing the Ontario Heritage Act (OHA), the Ministry of Municipal Affairs and Housing, is responsible for issuing the Planning Act (R.S.O. 1990, CHAPTER P.13, amended 2020, c. 6, Sched. 4). This Act "sets out the overall rules for planning in Ontario and describes how land-use may be controlled, and who may control them"(City of Guelph, 2018, p. 10). The Ministry is 
also responsible for Bill 107 - Getting Ontario Moving Act, Bill 108 - More Homes, More Choice Act, Bill 138 - Plan to Build Ontario Together Act, The Provincial Policy Statement (P.P.S.) 2020 and A Place to Grow: Growth Plan for the Greater Golden Horseshoe, 2019. In Ontario, "228 municipalities have enacted one or more (of) Part IV (OHA, section 29) designation by-laws under the Ontario Heritage Act" (Ontario Heritage Act Register, 2019, 1. 2). The OHA plays a significant role in the regulation of heritage and is the "guiding legislation which enables municipal and provincial governments to designate and manage properties and districts determined to be of cultural heritage value or interest in Ontario"(City of Guelph, 2018, p. 12). In 2005, the OHA was re-evaluated "to provide municipalities and the province with enhanced powers to preserve and promote Ontario's cultural heritage"(Ontario Ministry of Tourism, Culture and Sport, 2006, p. 1). The re-evaluation of this Act also led to the establishment of "over 75 area designations" across Ontario(Ontario Ministry of Tourism, Culture and Sport, 2006, p. 1).

Since its passage in "1975" (Schneider, 2019a, 1. 8), the Ontario Heritage Act 2005 signalled the first significant amendment in the history of the Act. It was widely accepted as it aligned with the strengthening of "heritage policies in the 2005 Provincial Policy Statement" (Schneider, 2019, 1. 10). Before this, it is said that the heritage community felt that the lack of updates to the OHA was "indicative of a bigger neglect of cultural heritage and its conservation as a government priority"(Schneider, 2019, 1. 10). A central part of heritage preservation in Ontario is the creation of Heritage Conservation Districts (HCDs).

The Ontario Heritage Trust notes that the "first HCD by-law, Meadowvale Village HCD, was established in Mississauga in 1980"(Ontario Heritage Trust, 2020, para. 2). These districts are defined as "an area with a group or complex of buildings, or a larger area with many 
buildings and properties... and also can comprise an entire municipality with a concentration of heritage resources"(Ontario Ministry of Tourism, Culture and Sport, 2006, p.5). Further, HCDs are "defined under Part V of the Ontario Heritage Act”(Ontario Heritage Trust, 2020, para. 2). They can "conserve areas of interest such as residential, commercial, a combination of residential/commercial, institutional, rural and 'main street' "(Ontario Heritage Trust, 2020, para. 4). Also, they often incorporate natural heritage features such as green open space(s), trees, parkland and waterways"(Ontario Heritage Trust, 2020, para. 4); see Figure 1 for the HCD designation process.

\section{Figure 1}

How Heritage Conservation Districts Become a Reality Flow Chart

\section{How a Heritage Conservation District becomes a reality}

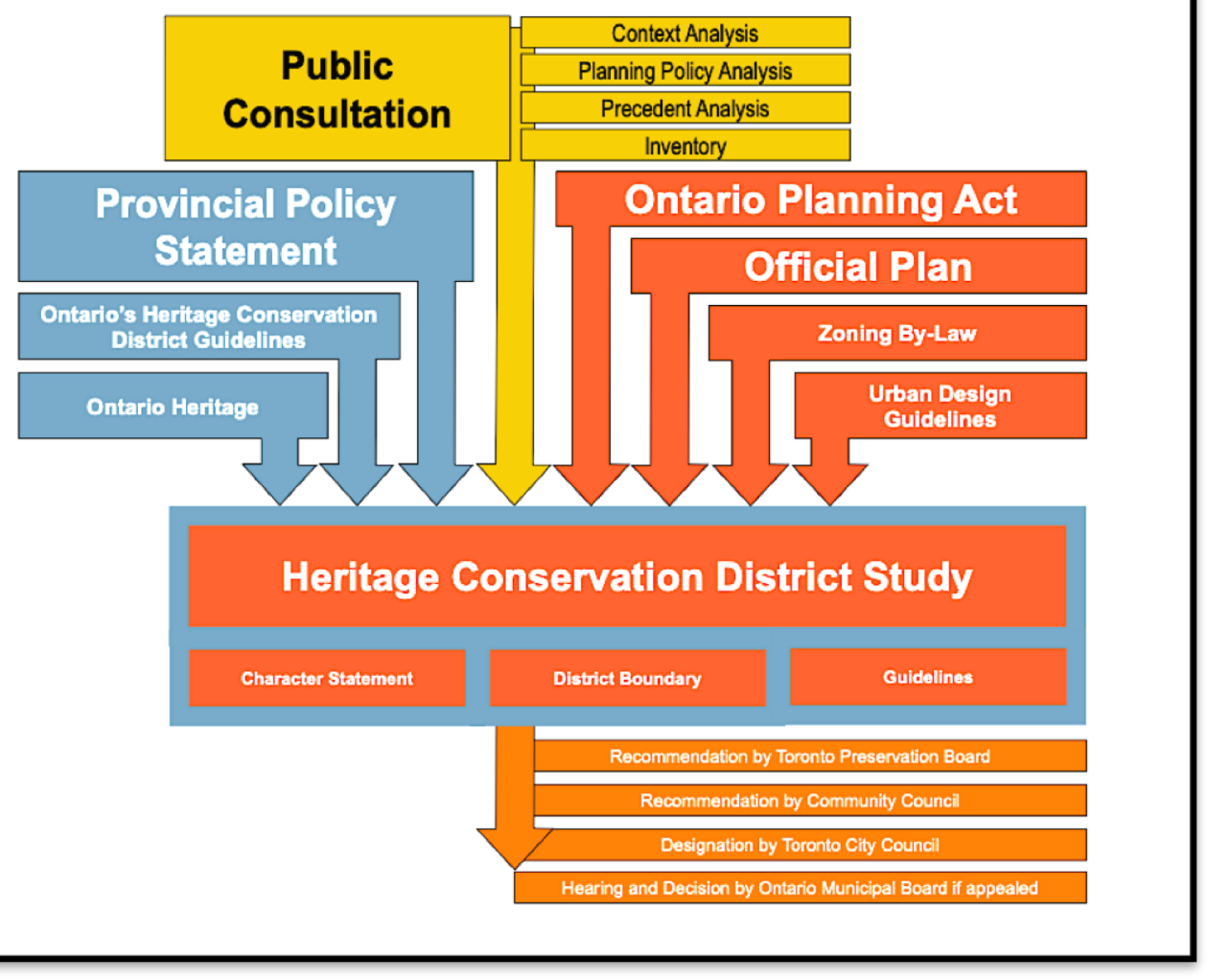

Note: Adapted from the Queen Street West Heritage Conservation District Plan, 2006. 
In Ontario's Heritage Conservation Districts, there are “approximately 23,000 properties” (Ontario Heritage Act Register \& Ontario Heritage Trust, 2019, 1. 4), and many scholars in the field of heritage conservation note that the number is so high because HCDs "do not have a negative impact on property values"(Robert Shipley et al., 2011, p. 617). The positive relationship between heritage designation and property value is not without flaws, as Heritage Toronto notes:

Permit delays and lengthy review times pose significant barriers to adaptive reuse projects. For developers and property owners who face monthly charges such as mortgage payments or construction crew salaries, these delays can make heritage property renovation unappealing and will discourage adaptive reuse of heritage properties. (Heritage Toronto, 2019b, p. 16)

Further, government rebate programs at the municipal level are "not substantial enough to offset the higher costs associated with redeveloping a heritage building (therefore) the funding is ineffective at preventing demolition or redevelopment projects ...”(Heritage Toronto, 2019b, p. 17). Environmental efficiency standards also continue to be an issue in heritage property designation. As of 2019, "there are no established practices or incentives that consider any environmental benefits resulting from adaptive reuse or heritage preservation"(Heritage Toronto, 2019b, p. 24). This means that "heritage property owners often face the difficult choice between financial incentives and heritage conservation" (Heritage Toronto, 2019b, p. 24). Still, across all of Ontario's municipalities' heritage properties have been embraced because, in 2019, it was noted that "over 7,300 properties...(were) designated under Part IV (Section 29) of the Ontario Heritage Act”(Ontario Heritage Act Register \& Ontario Heritage Trust, 2019, 1. 1). Overall, "designation allows a community to recognize and commemorate what it values within an area, 
that contributes to its sense of place. It provides a process for sustaining these elements into the future"(Ontario Ministry of Tourism, Culture and Sport, 2006, p. 5).

In 2019, “133 Heritage Conservation Districts (HCDs)”(Ontario Heritage Act Register \& Ontario Heritage Trust, 2019, 1. 3) were approved across the Province of Ontario. It is important to note that "a heritage designation encourages good stewardship and conservation by protecting the asset from demolition or alteration"(City of Guelph, 2018, p. 13). Still, “designation doesn't unconditionally prevent demolition from occurring. If a property is designated by a by-law under the OHA, a municipal Council can still approve demolition for a variety of reasons"(City of Guelph, 2018, p. 13). These reasons include the "novel interpretation"(Schneider, 2019, 1. 25) of the term 'conserved' by the Local Planning Appeal Tribunal (LPAT), which is outlined in the Provincial Policy Statements (PPS) and the unforeseen loopholes which some developers use in redevelopment proposals to push for the demolition of heritage properties.

These heritage properties may be deemed lower in cultural heritage significants because rules implemented before the OHA's 2005 amendments facilitate their categorization as such on a scale of heritage value. A clear example of this system is in the case of South Rosedale's Heritage Conservation District in Toronto, where pre-2005 OHA policies provided the space for an inconsistent "A-B-C rating regime"(Schneider, 2019, 1. 13). This rating system gave clause for the demolition of three homes in the area, which had "C-rating's" (Schneider, 2019, 1. 17) but was suggested to have a higher B-rating because of its connection to an "award-winning Toronto architect... and prominent landscape architects"(Schneider, 2019, 1. 21). This C-rating permitted the demolition of a property "if the proposed replacement building, is equally able or more able to contribute to the heritage character of the district'(Schneider, 2019, 1. 13). In the end, LPAT determined the developer's new property had more heritage character than the "mid-twentieth 
century" (Schneider, 2019, 1. 26) homes up for demolition, as they only had "characteristics of middling interest"(Schneider, 2019b, 1. 24). In Ontario, "heritage districts tend not to be grand residential precincts, such as one might find in New York, nor are they often like the classic neighbourhoods of Charleston, South Carolina"(Shipley et al., 2011, p. 617). These crucial sites are designated through "historical research and evaluation and aim to "promote understanding and appreciation of an area's heritage values and attributes"(Ontario Ministry of Tourism, Culture and Sport, 2006, p.5).

\subsubsection{Heritage Toronto and Heritage Conservation Districts (HCDs) in the City of Toronto}

Heritage conservation has been a part of the City's planning objectives for many years, as Heritage Toronto's predecessor, the “Toronto Civic Historical Committee, was established by City council in 1947" (City of Toronto-Chief Planner and Executive Director, City Planning Division, 2019, p. 6). The Toronto Civic Historical Committee was the 'first of its kind in Canada', and its early objectives were to preserve the "Fort York National Historic Site" (City of Toronto-Chief Planner and Executive Director, City Planning Division, 2019, p. 6). The organization was renamed the "Toronto Historical Board (THB), becoming an arm's length agency of the city and a registered charity in the 1960s"(Pietro, 2019, para. 1). Following these

changes, in 1967, the organization unveiled its first plaque, which commemorated the "volunteer reserve company that later became HMCS York"(Pietro, 2019, para. 2). The City notes that in the:

1970s with the help of provincial and federal funding, the THB conducted a street survey of all of the properties within the 1850 boundaries of the city, south of Bloor Street between Bathurst Street and the Don River, (as of) June 20, 1973, Toronto City Council adopted the first list of nearly 400 properties as the official 'Inventory of Heritage 
Properties. (City of Toronto-Chief Planner and Executive Director, City Planning

Division, 2019, p. 6)

At one point in time, the City could only "observe a short holding period before even a listed property could be demolished" (City of Toronto-Chief Planner and Executive Director, City Planning Division, 2019, p. 6). In the City of Toronto, HCDs have been designated "since 1985'(Acting Chief Planner and Executive Director, City of Toronto Planning Division, 2017, p. 5). Before an HCD designation can take place:

City Council must undertake an HCD study to determine if the area merits designation. Section 40 (2) of the OHA identifies the scope and required components of an HCD study. These include an analysis of the character and appearance of the district, recommendations for the district's boundaries; the objectives of the HCD plan; and recommended changes to the Official Plan and municipal by-laws, including zoning bylaws. (Acting Chief Planner and Executive Director, City of Toronto Planning Division, 2017, p.4)

In 1997 "under section 72 of the City of Toronto Act, ...(No. 2) City Council changed the name of the Toronto Historical Board (THB) to Heritage Toronto"(City of Toronto, 2019b, p. 4). Following this:

on December 16 and 17, 1998, City Council set out the framework for heritage governance in the City by adopting Clause No. 3 of Report No. 15 of the Special Committee to Review the Final Report of the Toronto Transition Team and established a new mandate and strategic focus for Heritage Toronto to deal with community issues, advocacy, major fundraising, publicity and public programs such as awards. In addition, 
the management of museums and preservation services were consolidated. (Relationship Framework For City of Toronto With Heritage Toronto, 2009, p. 1)

In 1999, "the new mandate and strategic focus of Heritage Toronto was encoded in Chapter 103, Article II - 'Heritage Toronto' of the City of Toronto Municipal Code"(City of Toronto, 2009, p.

1). The City of Toronto took "responsibility for the historic site museums and heritage preservation services"(Heritage Toronto, 2020, 1. 15). While Heritage Toronto "retained the agency and charity status, and responsibility for Plaques, Awards, and Tours programming" (Heritage Toronto, 2020, 1. 15). In 2002,“City of Toronto Official Plan adopted in November (of that year required) that a Heritage Management Plan be prepared and adopted by Council"(City of Toronto, Heritage Preservation Services, 2007, p. 3).

Policies in the City of Toronto's Official Plan seeks "to protect and manage cultural heritage resources, including significant buildings, properties, districts, landscapes and archaeological sites"(Acting Chief Planner and Executive Director, City of Toronto Planning Division, 2017, p. 5). Further, all HCDs in the City of Toronto are "legally protected by a municipal by-law, passed under Part V of the Ontario Heritage Act'(Barrett, 2012, p. 7). In 2003, "City Council adopted a template for Relationship Frameworks to be developed for all City boards"(City of Toronto, 2009a, p. 5).

After changes to the "Heritage Act and Planning Act in 2005 (took effect), the City's (heritage property) inventory began a healthier and steadier growth"(City of Toronto-Chief Planner and Executive Director, City Planning Division, 2019, p. 6). In 2006, "Heritage Toronto was continued as a City Board in the City of Toronto Act, 2006 "(Relationship Framework for City of Toronto With Heritage Toronto, 2009, p. 1). In "2007 Toronto City Council adopted in principle the Phase One Heritage Management Plan, providing City Planning with a framework 
and a strategy for the management of heritage resources as an important part of city building" (City of Toronto-Chief Planner and Executive Director, City Planning Division, 2019, p. 6).

Following the adoption of the Heritage Management Plan, a "Relationship Framework was approved by City Council in "October 2009" (Relationship Framework for City of Toronto With Heritage Toronto, 2009, p. 1). This framework defined "the relationship between the City and Heritage Toronto and sets out [the] Council's delegation of authority, expectations and requirements"(City of Toronto, 2020b, sec. Governance). In 2012, City Council adopted the document titled "Heritage Conservation Districts in Toronto: Procedures, Policies and Terms of Reference (HCDs in Toronto)"(Chief Planner and Executive Director, City Planning, 2015, p. 3). At the time:

'HCDs in Toronto' was developed in response to significant changes to the Ontario Heritage Act (OHA) and the Provincial Policy Statement [PPS] in 2005, as well as the City Council adopted Standards and Guidelines for the Conservation of Historic Places in Canada. (Chief Planner and Executive Director, City Planning, 2015, p. 3)

In the same year, the City of Toronto created:

an inclusive Official Plan Review Heritage Advisory Committee that helped plan and implement meetings and interviews with members of City Council, the City Heritage Preservation Board, representatives of the Preservation Panels of the various wards in the City, resident and ratepayer groups, the development community, provincial heritage officials, representatives of faith groups, and heritage consultants. (Williamson et al., 2017, p. 74)

In 2013, the City "established new policies for heritage resources ... as a component of the statutory periodic review of their Official Plan"(Williamson et al., 2017, p. 74). In 2014, “an 
official plan amendment with new heritage policies was subsequently passed by City Council (reflecting) the new powers and responsibilities available to Council to conserve heritage properties and archaeological resources"(Williamson et al., 2017, p. 75).

In 2017, City Council "adopted EX 24.2:Changes to Heritage Toronto Relationship Framework and Board Composition"(City of Toronto, 2020, sec. Key Council Decisions), which "defines the relationship between the City and Heritage Toronto and sets out Council's delegation of authority, expectations and requirements"(City of Toronto, 2020b, sec.

Governance). In the same year, the "Planning and Growth Management Committee directed staff to report back with recommendations for the prioritization of outstanding Heritage Conservation District Studies authorized by City Council, but not yet prioritized"(Chief Planner and Executive Director, 2018, p. 2). Following this in a:

January 2018 meeting, Planning and Growth Management Committee requested the Acting Chief Planner and Executive Director, City Planning, to report directly to City Council on means to advance the multi-year heritage work, program including consideration of retaining a temporary project manager in 2018 utilizing funding from the City Planning capital budget. (Chief Planner and Executive Director, 2018, p. 2) In 2019, the Toronto Municipal Code, Chapter 103, Heritage was revised, setting out "Heritage Toronto's mandate and the composition and responsibilities of its Board of Directors, which supervises the management of Heritage Toronto's business and affairs"(City of Toronto, 2020b, sec. Governance). Heritage Toronto continues to be responsible for the "public awareness, understanding and appreciation of Toronto's cultural, architectural, archaeological and natural heritage"(Ontario Ministry of Tourism, Culture and Sport, 2006, p. 5). 
Further, "working with the private sector, community organizations, and volunteers across the city, Heritage Toronto delivers city-wide heritage promotion and education services" (City of Toronto, 2020, 1. 4) and collaborates with relevant City departments, agencies, boards and corporations/commissions (ABCs) as well as Council. These collaborators also extends to Heritage Preservation Services (HPS), the Toronto Preservation Board, which is referred to as "the Toronto Municipal Heritage Committee and its Community Preservation Panels"(City of Toronto, 2009b, p. 3), which are under the larger umbrella of the City's Planning Division.

The Heritage Preservation Services (HPS) "identifies and works to conserve heritage properties and landscapes, primarily through the use of the City of Toronto Heritage Register, the creation of Heritage Conservation Districts, planning studies and surveys and the Archaeological Management Plan"(City of Toronto-Chief Planner and Executive Director, City Planning Division, 2019, p. 6).

As of 2019, there are "700 plaques" (Pietro, 2019, para. 2) identifying different aspects of heritage in the City and as a charity and agency of the City of Toronto. Heritage Toronto turned seventy in 2019, and in this milestone, Heritage Toronto continued to celebrate the "city's heritage ... (and) the diverse stories of its people, places, and events" (Heritage Toronto, 2019, p. 2). In the 2019-2020 annual report, Heritage Toronto's revenue was “\$1,155,571”(Welch LLP Chartered Professional Accountants, 2019, p. 4), and their expenses were “ $\$ 1,187,931$ ”(Welch LLP - Chartered Professional Accountants, 2019, p. 4).

The City of Toronto contributes “ $36 \%$ percent to Heritage Toronto's revenue" (Heritage Toronto, 2019a, p. 26). In comparison, 64\% comes from a combination of "sponsorships, special projects and grants, donations/memberships and tickets/fees"(Heritage Toronto, 2019a, p. 26). In regards to expenses, “67\% percent goes to public programing”(Heritage Toronto, 2019a, p. 26) 
while "33 percent goes to administration, communication and fundraising"(Heritage Toronto, 2019a, p. 26).

In the same year, Toronto City Council "unanimously adopted the recommendations of the City-Wide Heritage Survey feasibility study report initiating the launch of the first Phase in the City-wide Toronto Heritage Survey"(City of Toronto-Heritage Preservation Services, 2019, 1. 1). Following suit, Heritage Toronto published its most recent heritage report since 2015, entitled Changing the Narrative: State of Heritage. The report was the "culmination of consultations with 58 organizations and over 500 stakeholders"(Heritage Toronto, 2019b, p. 20). It presented many striking arguments and statistics about heritage, including the observation that " $35 \%$ of Torontonians are unaware of what defines a Heritage Conservation District"(Heritage Toronto, 2019b, p. 18).

Since 2001, Heritage Toronto's evidence-based reports have taken "the pulse of Toronto's heritage sector"(Heritage Toronto, 2019, p. 2). They note that they produce these reports:

- To provide measurable goals and recommendations for decision-makers.

- To provide a unified voice for the municipal heritage sector, which comprises a plurality of local community groups and volunteers.

- To maintain and deepen the relationship between Heritage Toronto and these groups and other stakeholders.

- To provide essential information on the sector to the general public. (Heritage Toronto, 2019, p. 2)

Further, Heritage Toronto's 2019 report championed various themes that are essential to consider when discussing HCDs. These themes include "social cohesion, economic development, and 
sustainability"(Heritage Toronto, 2019, p. 1). Throughout the report, they are used as section headings to contextualize Heritage Toronto's arguments about the state of heritage in the City. Heritage Toronto notes that social cohesion push's the notion that "heritage belongs to everyone"(Heritage Toronto, 2019b, p. 5) and also suggests that beyond representation, the heritage sector needs to promote "participatory approaches and genuine partnerships to (recognize the) entrenched power dynamics ... in the heritage sector"'(Heritage Toronto, 2019b, p. 5). The theme of economic development considers "how heritage contributes to the overall economic climate of (the) city, from how to adapt heritage buildings into modern residences and businesses to our understanding of employment trends and career opportunities within these sectors" (Heritage Toronto, 2019b, p. 13). Lastly, heritage sustainability concerns the notion that their needs to be an "increased focus on the creation of a comprehensive network of green spaces, parklands, and waterways that integrate Toronto's natural past with a sustainable future" (Heritage Toronto, 2019b, p. 22).

Through these substantive city-wide initiatives, it is clear that heritage preservation at the municipal level is a significant priority and warrants investigation, particularly with a public policybased lens. Since the 1980s, the city has been designating HCDs, amassing over " 20 designations"(Barrett, 2012, p. 7). Still, the designation of these districts is disproportional throughout the city's most suburban areas; this includes Scarborough, North York and Etobicoke/York and is defined by the City as a form of "geographic inequity"(City of Toronto-Chief Planner and Executive Director, City Planning Division, 2019, p. 5). Further, Heritage Toronto notes that "there is a need to balance heritage conservation with the city's growing development ... as the city undergoes rapid expansion”(Heritage Toronto et al., 2015, p. 9). 
This Major Research Paper (MRP), initially explored in a twelve-page Issue Analysis Paper for an Urban Governance elective course taken in January 2020 in the Masters of Public Policy and Administration program at Ryerson University (MPPA), builds on the foundation of the analysis and examines the disproportionate designation of Heritage Conservation Districts (HCDs) in the City of Toronto. These districts are heavily designated in the City's downtown core, compared to the most eastern part of the city. Two case studies of potential HCDs in Scarborough were chosen to illustrate the disproportionate designation of HCDs in the City, and they are known as Agincourt HCD and Midland Park HCD.

It is important to note that both case studies were not previously discussed in the Issue Analysis Paper, demonstrating the breadth of research conducted to expand on the initial paper. Before reviewing these cases, this MRP will examine the terminology used in heritage studies and presents an overview of HCD policy in the City of Toronto. Further, the major theoretical approaches which help contextualize the relationship between heritage conservation, indigeneity, multiculturalism and diversity are considered. Also, through an extensive examination of preexisting literature, the role and mechanisms of urban planning are discussed. Following this discussion, the history of urban planning in the City of Toronto is introduced, and the relevant Provincial legislation and bodies are identified. Which include the Local Planning Appeal Tribunal (LPAT) and Bill 108, the More Homes, More Choice Act. The concluding sections shed light on the various factors that contribute to heritage designation in the City. These factors create barriers for heritage designation in some districts, yet favour the social-cultural and historical attributes of others, which I've deemed ideal districts. These ideal districts have high heritage property designation levels and were part of Toronto before the 1998 amalgamation, which will be discussed in Chapter three. 


\subsection{Rational}

\subsubsection{Significance of Topic}

The topic of municipal heritage conservation is significant because, "in 2018, the City of Toronto reached its longstanding target of directly investing \$25 per-capita in culture (including the arts, film and entertainment industries, and museums and heritage)"(City of Toronto \& General Manager, Economic Development and Culture, 2019, p. 1). Although it is not clear if these per-capita targets include HCDs or its management specifically, the City has noted that it includes some form of heritage investment. These per-capita targets were "first established as part of the Culture Plan for the Creative City in 2003, when Toronto was investing \$14 percapita with a population of 2.4 million people"(City of Toronto \& General Manager, Economic Development and Culture, 2019, p. 1). The City of Toronto is said to "have made significant progress... but issues of equity and access to arts and heritage programs, affordable and sustainable space, adoption of new technologies and talent retention outside the downtown core remain"(City of Toronto \& General Manager, Economic Development and Culture, 2019, p. 1).

In addition, to the per-capita milestone, as previously mentioned in an earlier section of this MRP, a significant action that brings HCDs and heritage conservation into the forefront of the City's agenda was the initiation of the first phase of the City-Wide Heritage Survey. The unanimous adoption of the City-Wide Heritage Survey was in response to the 2017 CityWide Heritage Survey Feasibility Study that aimed to "scope and describe the initiative, identifying required operating costs and ... necessary resources"(City of Toronto-Heritage Preservation Services, 2019, p. 1). The first phase of the survey includes "the digital modernization of heritage data, the development and launch of an Indigenous Engagement Program, the initial planning of heritage survey volunteer and engagement programs, and the 
research and writing of historic context statements"(City of Toronto-Heritage Preservation Services, 2019, sec. Phasing).

Further, City "staff will also test and refine survey and engagement methodologies through the existing heritage study work program and through addressing the backlog of individual property nominations, to create efficiencies in evaluations and to assist in meeting service level demands"(City of Toronto-Chief Planner and Executive Director, City Planning Division, 2019, p. 13). Overall, the "Toronto Heritage Survey will be an essential tool for City Planning in the identification of heritage resources on development sites in advance of planning applications"(City of Toronto-Chief Planner and Executive Director, City Planning Division, 2019, p. 14) and is a significant step in the management and designation of HCDs in the City of Toronto.

Lastly, this research is significant because HCDs "are becoming more highly sought after as residential sanctuaries in otherwise overdeveloped urban core areas"(Hulley, 2016, 1. 22). This is especially true in Toronto, despite the COVID-19 pandemic, "Toronto's megadevelopment boom continues to reshape downtown Toronto as the city goes vertical'(Crew, 2020, para. 1). As an article on Canadian real estate suggests, "the future of the pandemic is unclear, (but) one thing is certain; expanded immigration and a growing tech industry, among other factors, have fueled a condominium boom in Toronto" (Crew, 2020, para. 18). This boom is most evident in the recent resuming of construction on "Canada's first supertall $(300+\mathrm{m})$ skyscraper" (Crew, 2020, para. 8), which will be located in downtown Toronto.

\subsubsection{Financial Implications}

In “2013” (Chief Planner and Executive Director, 2018, p. 3), a year after the City’s planning division started the Heritage Conservation Districts (HCDs) program, the "planning and 
growth management committee,...recommended that council direct the city planning division to build the base capacity to maintain five HCD studies [or] plans a year" (Chief Planner and Executive Director, 2018, p. 5). Further "incremental funding for the HCD Program of $\$ 0.500$ (thousand) in each of 2014 and 2015 resulting in base funding of \$1 million in 2016 onwards" (Chief Planner and Executive Director, 2018, p. 5).

The committee also notes that "two additional FTEs (full-time employees), dedicated exclusively to undertake HCD studies, would be required at a cost of $\$ 0.175$ (thousand) in order to increase the number of HCDs studies and plans underway" (Chief Planner and Executive Director, 2018, p. 5). In the "2014 Operating Budget included \$0.088 (thousand) in 2014 with annualized impacts of $\$ 0.088$ (thousand) in 2015 for... two recommended positions" (Chief Planner and Executive Director, 2018, p. 5). The "2015 Operating Budget included $\$ 0.239$ (thousand) in 2015 with annualized impacts of $\$ 0.171$ (thousand) in 2016, for four new positions, two senior heritage planner positions and two assistant heritage planner positions" (Chief Planner and Executive Director, 2018, p. 5).

In 2018 and 2019, the trend of allocating "\$0.500 (thousand)" (City of Toronto et al., 2018, p. 12), a year continued. Still, the City noted that over a ten-year span, they planned to invest “\$8.7 million to execute HCD related studies”(City of Toronto et al., 2018, p. 3). Between 2020-2029 the city plans to invest " $\$ 7.2$ Million or 12\% of their \$59.9 Million 10-Year Gross Capital Program budget" (City of Toronto, 2020a, p. 16) to heritage. When examining individual fiscal years, such as 2020, the city plans to invest “ $\$ 0.700$ (thousand)”(City of Toronto, 2020a, p. 28), but this decreases to " $\$ 0.400$ (thousand) in 2021" (City of Toronto, 2020a, p. 28), which will have a significant impact on the designation of HCDs. Further, changes to existing projects in the projected 2020-2029 Capital Budget and Plan "reflects a decrease of $\$ 4.015$ million over the 
nine common years (2020-2028)"'(City of Toronto, 2020a, p. 15). Among the projects, funding for "Heritage Conservation District Studies will decrease by ( $\$ 1.675$ Million)"(City of Toronto, 2020a, p. 15). The City planning division justified a decrease in spending on HCDs, among other items, by suggesting that:

Growth Studies and the Heritage Conservation District Program represent on average about $92 \%$ of the annual capital budget (and) typically have a multi-year delivery schedule and experience project underspending due in part to the timing of construction projects coordinated with partner divisions or complexity of studies. (City of Toronto, 2020a, p. 17)

City planning further notes that they will continue to review their capacity to deliver and adjust their 10-year capital plan to an "average $\$ 5.926$ million in yearly spending"(City of Toronto, 2020a, p. 17). Also, “as part of this review, \$2.881 million of unspent 2019 funds will be carried forward into 2020"(City of Toronto, 2020a, p. 17). Still, these funds' status is unknown, as the unprecedented effects of COVID-19 on the City's finances continue to evolve.

\subsubsection{Gap in research on Heritage Conservation Districts (HCDs)}

As mentioned in the introduction, there are only a handful of academic papers on Toronto's HCDs. Further, there is a gap in the literature because there seem to be no academic journal articles examining why Heritage Conservation Districts are distributed unevenly within the City of Toronto. This MRP presents a major step in examining this issue and adds to the standing research on HCDs in Ontario, which primarily focuses on heritage property designation, economic development, and community satisfaction. 


\subsection{Methodology}

The research for this MRP started in March 2020, and the method employed was qualitative. The method included the textual analysis of various primary documents, such as decision and heritage department correspondence letters, heritage conservation policy manuals, heritage blogs and board meeting minutes. Secondary documents such as HCD plans, slide decks from Toronto Heritage Preservation Services (HPS), supplementary reports, boundary maps, and City panels were examined. Further, the case study method was employed to analyze two potential Heritage Conservation Districts in the inner suburbs of Toronto, known as Scarborough. Official meeting minutes from the Scarborough's Community Preservation Panel, a subcommittee of the City's four Community Councils, were the primary data source for the case studies. It is important to note that no official city databases are dedicated to collecting official and community correspondence on potential HCDs.

The City's Heritage Preservation Services (HPS) website only provides information on HCDs in the designation process, being studied or under appeal through the Local Planning Appeal Tribunal (LPAT). Therefore, key search terms such as Agincourt, Midland Park and Heritage Conservation District were utilized to start and compile documents on each district. Case study-specific documents were digitally tagged, colour coordinated and further organized by year, document type and Ward, to help establish a clear timeline of events among the many documents and eliminate the overlap of information.

Agincourt's HCD was proposed in 2005, so there was a vast amount of information in the City's minutes and heritage preservation documents. On the other hand, with its recent nomination and unofficial status among other HCD study authorizations, Midland Park HCD 
data was primarily sourced from community association correspondence and website information, media coverage and Scarborough Community Preservation Panel Council minutes.

\subsubsection{Key Research Questions}

This MRP seeks to answer the following research questions:

1) What factors (social, economic, cultural, political) contribute to the prioritization of specific HCD designations over others in the City of Toronto?

2) What is the correlation between the disproportionate nature of HCDs and the lack of heritage priority designation in Toronto's inner suburban areas?

3) How can the City of Toronto reform municipal heritage designation criteria to increase the geographical equity of HCDs?

\subsection{Major Theoretical Approaches}

In this MRP, the key aspects of two major theories and a framework were considered to contextualize the intersections of urban policy, planning and heritage conservation. They include critical race theory, settler colonialism and critical urban theory. Delgado and Stefancic (2017) note that critical race theory (CRT) was put forth by "activists and scholars engaged in studying and transforming the relationship among race, racism, and power"(p. 3). The theory has its origins in the 1970s, when "advances of the civil rights era of the 1960s had stalled and, in many respects, were being rolled back"(Delgado \& Stefancic, 2017, p. 5). Further, “critical race theory builds on the insights of two previous movements, critical legal studies and radical feminism, to both of which it owes a large debt"(Delgado \& Stefancic, 2017, p. 5). As a "movement (CRT) considers many of the same issues that conventional civil rights and ethnic studies discourse take up but places them in a broader perspective that includes economics, history, setting, group and self- interest, and emotions and the unconscious"(Delgado \& Stefancic, 2017b, p. 3). It is 
important to note that the influences of conventional civil rights on CRT is connected to the notion of "redressing historical wrongs..."(Delgado \& Stefancic, 2017, p. 5), as well as “sympathetic understandings ... of community and group empowerment”(Delgado \& Stefancic, 2017 , p. 5). On the other hand, "from ethnic studies, it took notions such as cultural nationalism, group cohesion, and the need to develop ideas and texts centred around each group and its situation" (Delgado \& Stefancic, 2017, p. 6).

There are various critics of CRT, including; "Randall Kennedy, Daniel Farber and Suzanna Sherry"(Delgado \& Stefancic, 2017a, p. 102). For example, they note that "Kennedy took issue with the idea that minority scholars speak in a unique "voice" about racial issues. He also took the movement to task for accusing mainstream scholars of ignoring the contributions of writers of color"(Delgado \& Stefancic, 2017a, p. 102). Moreover, "some of the areas that drew critical attention are storytelling; the critique of merit, truth, and objectivity; and the matter of voice"(Delgado \& Stefancic, 2017a, p. 102). Still, the tenets of CRT offer an inciteful perspective to consider, one of the tenets suggest that "racism is ordinary, not aberrational'normal science, 'the usual way society does business, the common, everyday experience of most people of color in this country"(Delgado \& Stefancic, 2017, p. 8). Another tenet or theme of CRT states that the:

'social construction' thesis holds that race and races are products of social thought and relations. Not objective, inherent, or fixed, they correspond to no biological or genetic reality; rather, races are categories that society invents, manipulates, or retires when convenient.(Delgado \& Stefancic, 2017, p. 9)

Aligning with many of the tenets of CRT, "settler colonialism is an ongoing system of power that perpetuates the genocide and repression of indigenous peoples and cultures [and] includes 
interlocking forms of oppression, including racism, white supremacy, heteropatriarchy, and capitalism"(Cox, 2017, para. 1). Reflecting on the writings of Wolfe (2006), Bond and Inwood also note that "because of the permanence of settler societies, settler colonization is theorized not as an event or moment in history, but as an enduring structure requiring constant maintenance in an effort to disappear indigenous populations"(Bonds \& Inwood, 2016, p. 716). As a scholarly field, "settler colonialism studies arose from scholarship in Native American and indigenous studies that engages with postcolonial studies and critiques the post- in "postcolonial" as inappropriate for understanding ongoing systems of domination"(Cox, 2017, para. 1). Radcliffe suggests that:

research has also begun to unpack how dominant interests [which] (continuously [refers] back to questions of rule, generated by coloniality, modernity and settler nation-states) become codified and implemented in particular concatenations, reflecting social norms, as well as individual and institutional trajectories. (Radcliffe, 2017, p. 222-223) Hugill quoting Tomiak (2013) also points out that: settler urban development is partly a history of 'deterritorialization of Indigenous people'... [as] settler colonists achieved 'radical reconfiguration[s] of space' by pursuing a diverse range of expulsive tactics, including denying aboriginal title, the "entrenchment" of a private property system 'from which Indigenous people were excluded," and the creation a network of reserves. (Hugill, 2017, p. 6)

Within the context of the urban planning and policy, the framework of settler colonialism denotes that the "dynamics of coloniality [and] indigeneity occur not merely in specific 'Indigenous' localities; rather, they occur across a wider terrain”(Radcliffe, 2017, p. 224). Therefore "Indigenous enclaves are thus embedded analytically and empirically within multi- 
scalar dynamics of territorialization, even if indigeneity is only visible when found in marginal contained places"(Radcliffe, 2017, p. 224). Settler-colonialism is not without critique Hugill citing Mawani (2016) notes that:

settler-colonial theorizing has sometimes traded in crude binaries, including 'imposed divisions between settler and native, colony and settler colony, and land and sea' that are incapable of capturing the complexity of colonial power and the varied movement of 'people, ideas, and legalities" across a diverse range of imperial spaces. (Hugill, 2017, p. 6)

Aside from the criticism, settler-colonialism "offer a provisional blueprint for a comprehensive theory of the settler-colonial city"(Hugill, 2017, p. 6). Lastly, critical urban theory "involves the critique of ideology (including social-scientific ideologies) and the critique of power, inequality, injustice, and exploitation, at once within and among cities"(Brenner, 2009b, p. 11). Critical urban theory also "insists that another, more democratic, socially just, and sustainable form of urbanization is possible, even if such possibilities are currently being suppressed through dominant institutional arrangements, practices, and ideologies"(Brenner, 2009b, p. 11). Largely, critical urbanist and planner[s] are concerned with addressing:

the transformation of cities and urban space under contemporary capitalism; the role of the state and urban planning in mediating those transformations; the politics of urban socio-spatial exclusion and polarization along class and ethno-racial lines; and the possibilities for progressive or radical interventions and mobilizations to produce more socially just, radically democratic, and sustainable urban formations. (Brenner et al., 2011, p. 5) 
Further, it "differs fundamentally from what might be termed 'mainstream' urban theory - for example, the approaches inherited from the Chicago School of urban sociology, or those deployed within technocratic or neoliberal forms of policy science”(Brenner, 2009b, p. 11). Its primary influences are from the "writings of leftist or radical urban scholars during the post-1968 period - for instance, those of Henri Lefebvre, David Harvey, Manuel Castells, [and] Peter Marcuse"(Brenner, 2009b, p. 11). As Brenner notes, like any theory, "critical theory deserves to be subjected to careful scrutiny and systematic debate"(Brenner, 2009a, p. 19). Further, "because the process of capitalist urbanization continues its forward-movement of creative destruction on a world scale, the meanings and modalities of critique can never be held constant"(Brenner, 2009a, p. 19). Brenner et al. also note that "the development of critical approaches to the study of capitalist urbanization has been fraught with wide-ranging disagreements about any number of core theoretical, methodological, and political issues by Katznelson (1993) Saunders (1984), Soja (2000)"(Brenner et al., 2011, p. 5). Overall, "critical urbanists must work to clarify and continually redefine the 'critical' character of their theoretical engagements, orientations, and commitments in light of early twenty-first century processes of urban restructuring”(Brenner, 2009a, p. 21).

So how do these various theories help contextualize HCDs in Toronto? Well, when discussing heritage planning in the City of Toronto, one has to look at its place within the larger argument of cultural heritage value. Further, the pre-existing discourse around race, diversity and multiculturalism, which are entrenched in the political and policy agendas of all three levels of government in Canada, complicate the culture and heritage value debate. The question of who's cultural value is being recognized, celebrated and designated becomes a looming question within the larger argument of heritage conservation. The tenents of critical race and critical urban theory 
can help assist our understanding of the relationship between multiculturalism and heritage planning as a policy tool. Multiculturalism is defined broadly by Qadeer as "a social condition, political ideology, public policy, or project that, occurring in various combinations, helps realize the recognition and expression of cultural and ethnic diversity within a nation or its parts"(2016a, p. 21). In Canada, Multiculturalism was "first adopted at the federal level in 1971, only four years after the transition of Canadian immigration policy from a white-only to a nominally colour-blind system"(Goonewardena \& Kipfer, 2005, p. 671). Further, Goonewardena and Kipfer note that it:

emerged initially as a response not so much to radical black anti-racism and antiimperialism (as in the British case of Race Relations) or to civil rights activism and black power politics (as in the US case of Affirmative Action), but to the demands from primarily European immigrant groups and the challenges of Québéquois, nationalism, which at times took on increasingly left-leaning and anti-imperialist dimensions. (Goonewardena \& Kipfer, 2005, p. 672)

In addition, "since the 1980s with an increasing number of immigrants coming from Asia, Africa, and South and Central America Canada's ethno-cultural diversity over the past three decades has become increasingly racialized" (Guo \& Wong, 2015, p. 1). As Guo and Wong have affirmed, "Canada's multiculturalism policy has evolved from song and dance in the 1970s, to anti-racism in the 1980s, to civic participation in the 1990s, and to fitting in in the 2000s" (2015, p. 4). However, the notion of multiculturalism is not without critique "die-hard defenders of multiculturalism can also become impassioned critics, even as they remain firmly circumscribed by the limits of liberal pluralist ideology and [quoting, Croucher, 1997], the myth of 'ethnic harmony' "(Goonewardena \& Kipfer, 2005, p. 673). As Qadeer suggests, "given 
Canada's relatively small population (33 million in 2011), the continual inflow of 225,000 to 280,000 immigrants (temporary foreign workers apart) per year will add up to $25 \%$ [to] $28 \%$ of its population being foreign-born by 2030"(Qadeer, 2016b, p. 42). In 2015, it was recorded that the City of Toronto’s racialized population was “47 percent”(Guo \& Wong, 2015, p. 1). In 2016, Statistics Canada census data showed that "the Toronto CMA was home to 3,011,905 people identifying as visible minorities or $51.4 \%$ of its population, the first census above the $50 \%$ mark, (representing) 77.5\% of Ontario's total visible minority population (see Figure 2),'(Office of Economic Policy \& Ontario Ministry of Finance, 2017, p. 2).

\section{Figure 2}

Visible Minorities in the Toronto Census Metropolitan Area's (CMA

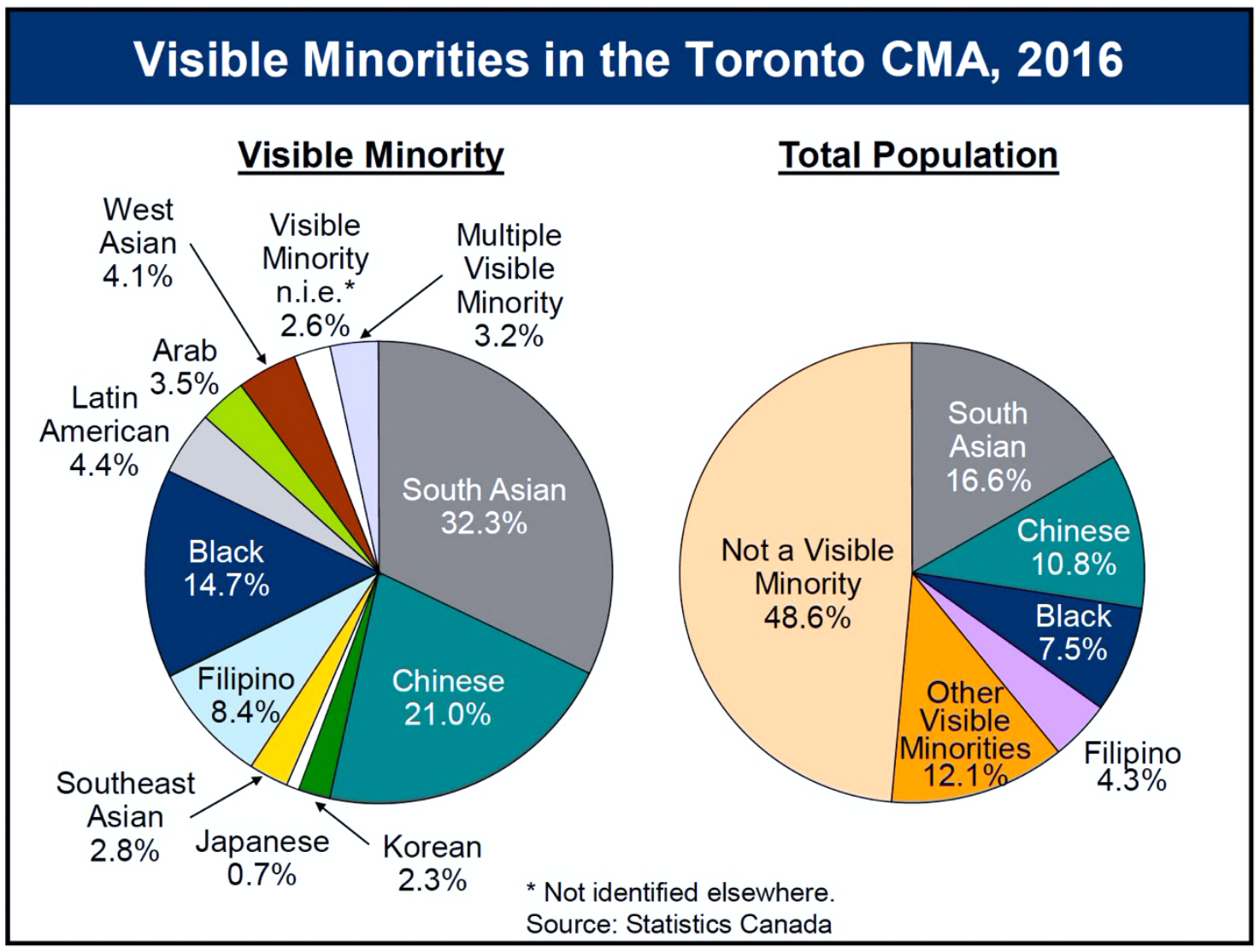

Note: Adapted from a screengrab of a chart from the Office of Economic Policy Labour Economics Branch, fact sheet 9, Ontario Ministry of Finance, 2017. 
These stats feed further into the underline diversity discourse that the City of Toronto has utilized since the early 2000s. As Viswanathan notes, Toronto has promoted:

two different discourses of diversity, one based on access and equity, and the other based on economic development, [which] emerged during the course of Toronto's amalgamation into a mega-city, and these were manifest through the governance restructuring of the city. (Viswanathan, 2009, p. 174)

Further, the City of Toronto's longstanding motto:

'Diversity, Our Strength' morphed from a simple and meaningful one, emerging from equity as representation and recognition of diversity in the city, into a corporate logo-still positive in its message--but crucial to the economic development of the city. (Viswanathan, 2009, p. 174)

The incorporation of diversity in a city that contains over $50 \%$ visible minorities lacks a critical approach to both the positive and negative aspects that arise with the discourse of diversity, as Viswanathan suggest "sugarcoating"(2009, p. 174) the issues. Further, an anonymous policy advisor working for the City of Toronto notes that "what the city failed to understand [was] ...resolving the contradictions of plurality [was] not really the point. Diversity per se is unmanageable ..."(Viswanathan, 2009, p. 175). The advisor further expressed that "there is this inherent fear [from the cities perspective] of a social breakdown because of (a) cacophony of disparate voices, all talking at the same time, pulling in different directions"(Viswanathan, 2009, p. 175). Further:

a pluralized citizenship parallels a struggle for equity in planning. Both are rooted in groups' refusals to be relegated to a minority status and by a mammoth effort to uphold 
their right to contribute to society and to participate at par with other groups.

(Viswanathan, 2009, p. 175)

Also, understanding the relationship between heritage planning, diversity, settler groups ,and indigeneity is crucial. To clarify, as "a cross disciplinary concept...indigeneity can be defined as the socio-spatial processes and practices whereby Indigenous people and places are determined as distinct (ontologically, epistemologically, culturally, in sovereignty, etc.) to dominant universals"(Radcliffe, 2017, p. 221). Further, it's important to recognize that the "production of a subaltern or politicized indigeneity hence requires complex, time-consuming negotiations across language, location, citizenship status, histories of resource control, gender, generation and education between diverse subjects, as the emancipatory valence of indigeneity is neither natural nor automatic"(Radcliffe, 2017, p. 223). This is due to the fact that:

the emergence of the modern 'Western' state, nation, and national subject (specifically, in the case of the Canadian settler society) were bound in an isomorphic relation that was central to their constitution as such. Defining national subjects as deserving of sovereign status and access to the rights extended by the state, Indigenous and immigrant populations were constituted as racially distinct and hence as belonging to different orders of (in)humanity. (Thobani, 2014, p. 301)

All of this considered, the settler colonialism framework becomes essential to arguments put forth in this MRP, as claims of heritage among the intersections of planning and policy, "move beyond binary logic, specifically colonial frontier logic that frames insiders as Canadians and outsiders as Aboriginal people"(Peters \& Kearns, 2013, p. 92) and helps "to see Aboriginal, people as ... 'contemporary people' steeped in traditional knowledge of place"(Peters \& Kearns, 2013, p. 93). 


\section{Chapter Two: Literature Review}

\subsection{Introduction}

This literature review examines the various concepts and terms that contribute to the contextualization of Heritage Conservation Districts (HCDs). The scholarly examination of HCDs in Canada is limited to a handful of peer-reviewed articles and major research papers and dissertations. Scholars with backgrounds in history, planning, and heritage conservation are responsible for most of the peer-reviewed HCD articles. These scholars examine various issues that include perceptions of heritage, heritage properties, heritage value, and economic impact. Outside of the academic realm, HCDs are discussed at length in district and planning studies conducted by preservation, urban planning, and architecture firms on behalf of various municipalities in Ontario. This literature review is organized by theme and will examine the overarching factors that contribute to the understanding of HCDs as a planning tool. This includes urban planning, criticism of urban planning, the theorization of urban planning, urbanism and heritage urbanism.

Before delving into the literature review's main components, this MRP will also mention the mechanism behind the study of urban heritage. Urban heritage is primarily defined as a planning tool. It is a critical issue in many cities around the world because heritage, in the urban context, can no "longer be conceived as a separate reality, a walled precinct protected from the external forces of change by plans and regulations" (Bandarin et al., 2015, p. 2). Karlström (2014) notes that urban heritage holds a position that is "in-between" (p. 7540). The unsettled nature of urban heritage contributes to the complexity of creating heritage policies.

Heritage sites in the urban space are "constantly changing and under the threat of being destroyed due to the nature of urban development" (Karlström, 2014, p. 7540), but they are also 
“protected and conserved because of its historical value”(Karlström, 2014, p. 7540). The latter aspect of this in-between has pushed urban heritage preservation to the forefront of government policy agendas, particularly at the municipal level. The relationship between governance and heritage adds additional complexity since governing bodies neglect to "comprehend its multiple connections and relationships"(Ripp \& Rodwell, 2016, p. 82). Among other factors, urban heritage governance and the actors involved are stuck in an "early post-second World War model that only predicated the survival of highly selected designated heritage (sites)"'(Ripp \& Rodwell, 2016, p. 82).

\subsection{Urban Planning}

As noted, HCDs are used as planning tools and, by extension, are a mechanism of urban planning and the sub-discipline heritage planning. With planning comes many definitions, and most echo each other with a slight variation on what urban planning is; on the other hand, most if not all of the literature agrees that urban planning is used to manage and help the development of cites (Bandarin et al., 2015; Jonas et al.; 2015; Monclús \& Guàrdia, 2006; Qadeer, 2016). For example, Jonas et al. consider urban planning "as an institution of the state that is primarily responsible for designing and managing how the flows of investment circulate in and out of the built environment”(Jonas et al., 2015, p. 15).

They also suggest that it is a "socio-spatial process because it is a future-oriented activity in which actors of various types engage so they can govern how the development will take place" (Jonas et al., 2015, p. 15). These "professional practitioners may analyse the problems and indicate solutions, but politicians have to make the final decisions, therefore "planning is as much social and political as it is technical, if not more so"(Hall, 2020, p.4). Hall notes that "planning systems exist throughout the world to address the major strategic issues of urban areas 
but are usually most effective at a small scale trying to fix local issues and disputes"(Hall, 2020, p. 7). He further surmises that a characteristic central to "all planning systems is the need to intervene in the process of urban and rural development to try to achieve an outcome that is more in line with the public interest'(Hall, 2020, p. 4).

Both Hebbert (2006) and Qadeer (2016) link urban planning to Anglo Saxon or AngloEuropean “cultural precepts”(Qadeer, 2016d, p. 216). Historically, planning or urban planning, (which are used interchangeably in this MRP) were in the "purview of a few visionaries funded by private donors"(Jonas et al., 2015, p. 15). Fainstein (2009) suggest that the:

profession of city planning was born of a vision of the good city. Its roots lie in the nineteenth-century radicalism of Ebenezer Howard and his associates, in Baron Haussmann's conception of creative destruction, and in the more conventional ideas of the urban progressives in the United States and their technocratic European counterparts" among other views. (p. 19)

Urban planning is now viewed as a rational, comprehensive, professionalized and bureaucratized discipline (Jonas et al., 2015, p.16; Bandarin et al., 2015, p. 1). The multilayered nature of urban planning directly connects to the notion of the multilayered city.

Colavitti (2018) defines the multilayered city as urban space that "contains the territory and landscape (as well as) complex objects that register an often almost unknown variety of situations and variables"(p. 36). The concept of the multilayered city, first coined in 1950 by Braudel, relies on "the knowledge of the morphology of the places, the understanding of the historical process of their building, the acknowledgment of their roles"(Colavitti, 2018, p. 131). Multilayered urban planning can use the "archaeological knowledge and topographic method to interpret the marks of the urban transformation through the reading and the knowledge 
of city's form and historic human presence"(Colavitti, 2018, p. 35). Colavetti (2018) suggests that "urban planning should use archaeological knowledge and topographic method[s] to interpret the marks of the urban transformation through the reading and the knowledge of city's form and historic human presence"'(p. 35).

In the policy context, urban planning is essential to the success of cities because it is said to have fully developed "in the twentieth century, with the aim of governing large-scale urban growth and urban rehabilitation processes"(Bandarin et al., 2015, p. 1). As a policy tool, urban planning is used to address issues of "land use, physical design, housing, community services, economic development, environment, transportation, and infrastructure"(Qadeer, 2016d, p. 216).

In addition, one of the most important manifestations of urban planning practice is zoning, which is defined as the separation of different land uses "in a manner that is written down in a policy document and protects vulnerable people or land uses from being polluted or otherwise endangered by other activities"(Jonas et al., 2015, p. 15). Scholars have different ideas on the most effective use of urban planning. Bandarin et al., for example, suggests that it's most effective in addressing social changes such as "rural-urban migrations, the rise of mass public and private transport systems, as well as planned industrial growth"( 2015, p. 1). Bolay notes that urban planning is best used to determine the "potential and the limitations of the natural (spatial and environmental) and human entities, including in its analysis the causes and impacts of the dynamics that affect the transformation of the city and its dweller"(2020, p. 57). Marcuse (2009), on the other hand, suggests that urban planning should be:

used as a way of raising concretely, the structural issues that underlie the creation and exercise of power in social relationships, power that both produces distributional injustices and more broadly inhibits the attainment of a good, or humane, or just city. 
(p. 91)

The various opinions presented demonstrate the complexity of urban planning in theory and in practice; therefore, in the next section, the theory of urban planning will be addressed.

\subsection{Theorization of Urban Planning}

The role of theory in planning has had a mixed reception since its early days as many planning professionals feel that “...planning is an applied field, and most planning students become practitioners, not academic researchers"(Fainstein \& DeFilippis, 2016, p. 3). Qadeer suggests that "planning theoreticians, tend to concentrate on the processes of plan-making, and not much on the actual policies that form the substance of plans"(2016, p. 221). To add to this mixed reception and lost opportunities for planning theory, LeGates \& Stout (2011) further suggest the following:

urban planning theory has been buffeted by a series of conflicting approaches proposed by Marxists, advocacy planners, equity planners, pluralists, disjointed incrementalists, probabilistic planners, systems planners, green urbanists, ecological designers, feminist planners, and communicative action theorists. Perhaps as a result of such a variety of approaches, a humbler, pluralistic, more realistic and flexible approaches to urban planning theory have... emerged. (p. 370)

Examining the critique of planning from a political viewpoint, Fainstein suggests that the left, center and right all provide different perspectives on what urban planning lacks. She notes that the left such as "Gans, Harvey, Davidoff, Reiner, Yiftachel, Purcell and Thomas"(Fainstein, 2009, p. 19) have "attacked planning for its class bias, for its anti-democratic character and for its failure to take account of difference"(Fainstein, 2009, p. 19). Scholars of the right, such as "Hayek, Anderson (and) Klosterman"(Fainstein, 2009, p. 19), see "planning as denying freedom 
and producing inefficiency (and) regards markets as the appropriate allocators of urban space" (Fainstein, 2009, p. 19). Centrists scholars, on the other hand, such as "Altshuler, Lindblom, Jacobs (and) Hall"(Fainstein, 2009, p. 19), suggest that "comprehensive planning is inherently undemocratic and unattainable, seeing the modernists' efforts to redesign cities as destructive of the urban fabric and indifferent to people's comfort and desires"(Fainstein, 2009, p. 19).

Critiques aside, the origins of urban planning theory have shifted, but the foundational theorist and text still take-up room in its discussion and practical applications. Fainstein and DeFilippis (2016) suggest that there are three key complexities to planning theory. First, they indicate that "planning theory overlaps with theory in all the social science and design disciplines, making it difficult to limit its scope or to stake out a turf specific to planning”(p.1). Second, they note:

That [the] field of planning is divided among those who define it, according to its object (producing and regulating the relations of people and structures in space), and those who do so according to its method (the process of decision making as it relates to spatial development). These different approaches lead to two largely separate sets of theoretical questions and priorities that undermine a single definition of planning. (Fainstein \& DeFilippis, 2016, p. 1)

Third, they note that "planning theory is further divided into those who understand planning through analyzing existing practices and those who theorize to transform planning practices. Thus, planning theory may be either explanatory or normative" (Fainstein \& DeFilippis, 2016, p. 1).

There are many theorists cited as the shapers of urban planning, but in the eighteenth century, Ebenezer Howard's and his text the Garden City is widely noted and discussed (Hall, 
2020; Bandarin \& Oers, 2012; LeGates \& Stout, 2011; Carmona, 2010; Sandercock, 1998). Hall notes that Howard's works and argument are widely cited because "Howard and his associates carried their ideas into bricks and mortar by building the world's first two garden cities, Letchworth and Welwyn, in England"(Hall, 2020, p. 12). In addition to Howard, LeGates and Stout (2011) cite "Daniel Burnham's monumental City Beautiful projects, the prescient regional plans of eccentric Scottish biologist Patrick Geddes, Le Corbusier and his modernist followers, Frank Lloyd Wright's brilliant Broadacre City vision" (LeGates \& Stout, 2011, p. 369). Wheeler \& Beatley (2014) note:

...to throw prevailing modes of urban planning into question during the second half of the twentieth century, to challenge the view of the planner as a detached, scientific expert, and to fuel calls for greater public participation and contextual, culturally informed understandings of urban problems. (p. 35)

Authors such as David Harvey, Manuel Castells, Robert Beauregard, Christine Boyer and Mike Davis "examine the often bizarre and inequitable urban landscapes created by capitalism and local governments working hand-in-hand"(Wheeler \& Beatley, 2014, p. 35). Jane Jacobs is also one of the most widely cited critics and urban theories informing scholars in urban planning. Wheeler \& Beatley (2014) note that Jacobs's “1961 book The Death and Life of Great American Cities was the bombshell that shocked many people around the world into questioning prevailing modes of urban planning"(Wheeler \& Beatley, 2014, p. 35).

Further, Jacobs is said to have "berated the simple-mindedness of single-use zoning and 'comprehensive' redevelopment in urban areas...instead, she advocated mixing land uses, and leaving many so-called slum areas alone to 'un slum' themselves”(LeGates \& Stout, 2011, p. 395). Lastly, Qadeer notes that "purveyors of the theory of postmodern urbanism, sometimes 
called the Los Angeles school of urbanism, namely, Michael Dear, Edward Soja, and Allen Scott are also important in the contemporary argument of urban planning"(2016c, p. 12).

\subsection{Critique of Urban Planning}

Along with the praises of urban planning, there is ever-growing and robust criticism. Bolay suggests that the "difficulty with urban planning is that it is based more or less explicitly on different disciplines (urbanism, architecture, engineering, economics, sociology, geography, etc.), that function independently with no formal obligation to work together/crossreference"(2020, p. 57). Wheeler and Beatley (2014) also note that:

despite many good intentions, urban planning in the twentieth century often proceeded in directions that were profoundly unsustainable. Planners promoted freeways and other automobile infrastructure without considering their sprawl-inducing impacts, authorized the bulldozing of vibrant older urban neighbourhoods for redevelopment into bland, modernist apartment blocks. (p. 35)

One of the main critiques of urban planning amongst scholars is the role of neoliberalism in urban planning (Wang \& Aoki, 2019, Jonas et al., 2015). Neoliberalism in the policy context can be defined "as a policy framework-marked by a shift from Keynesian welfarism towards a political agenda favouring the relatively unfettered operation of markets"(Larner, 2000, p. 5). Wang and Aoki expand on this notion by noting that the "force of neoliberalism has highly influenced urban policies that facilitate market-oriented economic growth and elite consumption practices, such as place making, public-private partnership, and property-led redevelopment"(Wang \& Aoki 2019,p.156; Brenner \& Theodore, 2002).

Campbell et al. note that "planning, as concept and practice, is written about from the vantage points of grand narratives about public policy (e.g., neoliberalism or deliberative 
democracy) as well as the particularities of everyday practices (e.g., dull-minded bureaucrats or accomplished mediators)"(Campbell et al., 2014, p. 188). They further note that "planning is criticized both for being too pro-growth and too anti-growth: for exclusionary practices that favor dominant interests, hence fostering injustice and inequality, and yet simultaneously for imposing undue constraints on the freedoms of businesses and communities"(Campbell et al., 2014, p. 188). Jonas et al. suggest that a tangible example of the way neoliberalism can manifest in planning is through "private contracting with the state"(Jonas et al., 2015, p. 16).

Another criticism is modernism's role in urban planning (Qadeer, 2016; Sandercock, 1998). Modernism perpetuates the notion that planning is " 'a good thing', a progressive practice and that its opponents are reactionary, irrational, or just plain greedy"(Sandercock, 1998, p. 4). Further, "it is assumed that planners know or can divine 'the public interest' and possess an expertise that ought to prevail (in a rational society) over politics"(Sandercock, 1998, p. 4). There is also a question of planning systems' effectiveness as these mechanisms "do not necessarily mean that the local system is effective or that it achieves much of value"(Hall, 2020, p. 3). Further, urban planning has neglected to create an environment that facilitates the "progressive decentralization of social decision-making processes"(Bandarin et al., 2015, p. 1). Echoing the ineffectiveness of planning, Colavitti contends that the process of urban planning: should make sure that, in every physical transformation of the city and territory, the consumption of some (substitutable) territorial resources is compensated by the increase of others, thereby producing a necessary rebalance of the ecological footprint, in terms of a more general compensation, not only environmental but also social-cultural. (2018, p. 129) 
Moreover, the dominance of the Anglo-European traditions in urban planning, mostly "dominant in the 'built environment' and inscribed with these so-called universal precepts, [prevail] the culture of the dominant community"(Qadeer, 2016d, p. 219). The dominance of these tradition perpetuates "straightforward chronological accounts, with the authors' allegedly impersonal, objective voice being the sole point of view, written from inside the profession"(Sandercock, 1998). Lastly, Qadeer notes "that planners' and their political masters' lack ...sensitivity to cultural rights [which]... facilitate[s] the exclusion of voices and stories of minorities, women, and other citizens"(Qadeer, 2016d, p. 219).

\subsection{Urbanism}

The intersections of urbanism and planning are defined by Hebbert (2006), who suggests that "planning is rooted in social reformism, giving its practitioners a happy sense of their own rectitude"( p. 86), while urbanism as "a shared culture or common ground between architecture and engineering [and] owes more to the pluralism of real urban politics"(2006, p.89). Then again, Jonas et al. (2015) suggest that urbanism is a "way of life that define cities in specific historical periods. These ways of life, of course, shape and are shaped by the design of urban built environments" (p.14). Jonas et al. (2015) also note that urbanism "helps us focus on urban places as fundamentally peopled - how they live, how they negotiate processes of change, and how they manage their relationships with each other, with social processes and institutions"(p. 15). Other scholars are surmised to have had a significant influence on the notion of urbanism include "Emile Durkheim, Georg Simmel and Louis Wirth and the Chicago School of urban sociologist, Lewis Mumford and Herbert Gans"(Jonas et al., 2015,p. 15; Monclús \& Guàrdia, 2006, p. xv). 
Jonas et al. suggest that Georg Simmel and Louis Wirth concluded that "city dwellers ...behave and interact differently than their rural or small-town counterparts" (2015, p. 15). This resulted in the fact that Urbanism as a way of life, "involved people developing a protective shell around themselves, so as to manage their increasing interactions with larger and larger numbers of strangers"(Jonas et al., 2015, p. 15). On the other hand, Jones et al. further suggest that the notion of 'anomie' is what connects urbanism and Durkheim. Anomie "is one of the classic frameworks of sociological research (and was) defined and popularized by the founding father of modern sociology, Emile Durkheim”(Huschka \& Mau, 2006, p. 468). Crutchfield and Bates note that 'Durkheim ([1893] 1956) used the French word anomie, meaning 'without norms,' to describe the disruption that societies experienced in the shift from agrarian, village economies to those based on industry"(Crutchfield \& Bates, 2001, p. 164). Huschka and Mau further suggest that:

Anomic forms are situations in which integrative mode of organic solidarity is disrupted, for example if social inequalities grow too large, social injustices and a lack of opportunity are apparent or if a growing polarization of social groups makes moral integration difficult.( 2006, p. 469)

Robert Merton also explored anomie, "Merton (1949) used the concept anomie to describe how social structure produced individual deviance" (Crutchfield \& Bates, 2001, p. 165). Huschka \& Mau note that “though Merton based his concept for the most part on Durkheim's idea of anomie as a normless state of society, he was primarily interested in the disjunction between culturally devised goals and accepted means of achieving these ends" (2006, p. 469). These two perspectives on anomic forms connect back to the notion that urbanism can sometimes perpetuate isolation and further be considered a "symptom of urbanism" (Jonas et al., 2015, p. 
15; Monclús \& Guàrdia, 2006, p. xv). Lastly, Monclús and Guàrdia note that among other things, "strategic planning ... and renewal of the post-Fordist cities, have led to a reconsideration of the economic, social and cultural dimensions of urbanism"(Monclús \& Guàrdia, 2006, p. xv).

\subsection{Heritage Urbanism}

Considered a "new paradigm”(Obad Šćitaroci et al., 2019, p. ix) in the contextualization of urban heritage preservation is heritage urbanism (HERU). HERU is defined as "the revitalization and enhancement of heritage through the context of spatial and urban planning and landscape and finds models for its integration into modern living”(Obad Š́citaroci et al., 2019, p. ix). First discussed in 2014, in a University of Zagreb, Faculty of Architecture research project entitled "Urban and Spatial Models for the Revival and Enhancement of Cultural Heritage”(Obad Šćitaroci \& Bojanić Obad Šćitaroci, 2019, p. 1).

Heritage urbanism's goal is to "contribute to the enhancement of heritage and create motivation to start seeing heritage as an active subject in space, where its emanation is felt, instead of viewing it as a static object”(Obad Šćitaroci \& Bojanić Obad Šćitaroci, 2019, p. 2). Similar to the previous iteration of urbanism, heritage urbanism differs because it focuses on urban constants. These constants are the "urban landscape (built structures), vehicle and pedestrian flows, public areas and the landscape, infrastructural systems"(Obad Šćitaroci \& Bojanić Obad Šćitaroci, 2019, p. 6). The key to heritage urbanism is its methodological levels as displayed in Table 1 below.

The methodological components include "factors, criteria and models for heritage rehabilitation. The factors include those of identity, influence and value, while the criteria and models help to enhance and revitalize heritage"(Obad Šćitaroci et al., 2019, p. xii). 
When examining heritage conservation districts, it is important to understand that an "urbanistic view on heritage implies an integral approach, which includes many different perspectives" (Obad Šćitaroci et al., 2019, p. x).

Table 1

Heritage Urbanism Methodology

\begin{tabular}{|c|c|c|c|}
\hline Factors & Factors of Identity & Factors of Effect & Value Factors \\
\hline & $\begin{array}{l}\text { Factors of Identity } \\
\text { include determining the } \\
\text { basic characteristics of } \\
\text { heritage, its features of } \\
\text { identity, which make it } \\
\text { recognizable, authentic } \\
\text { and original. } \\
\text { This primarily consists } \\
\text { of exploring the spatial, } \\
\text { urban, architectural, } \\
\text { landscape, cultural and } \\
\text { historical features, } \\
\text { complemented with } \\
\text { other features depending } \\
\text { on the type and character } \\
\text { of the heritage. It is } \\
\text { essential to identify the } \\
\text { current and the historical } \\
\text { context. }\end{array}$ & $\begin{array}{l}\text { Factors of influence should } \\
\text { be separated from the } \\
\text { research context. These } \\
\text { factors show how and to } \\
\text { what extent the context } \\
\text { affects the state and the } \\
\text { character of the heritage, } \\
\text { what changes have occurred } \\
\text { in the past regarding reuse } \\
\text { and adaptation, in what way } \\
\text { the current spatial and social } \\
\text { context affects the status } \\
\text { and opportunities } \\
\text { for heritage enhancement, } \\
\text { and whether future positive } \\
\text { or negative influences can } \\
\text { be expected. }\end{array}$ & $\begin{array}{l}\text { Factors of value are } \\
\text { determined for every } \\
\text { example of cultural } \\
\text { heritage individually, } \\
\text { depending on its } \\
\text { identity and the } \\
\text { influence of context. } \\
\text { Valorisation of } \\
\text { heritage } \\
\text { enables scientifically } \\
\text { founded and a } \\
\text { professional } \\
\text { determination of } \\
\text { criteria for new } \\
\text { interventions in } \\
\text { heritage, regardless of } \\
\text { whether these } \\
\text { interventions refer to } \\
\text { the enhancement of } \\
\text { heritage that is in } \\
\text { good condition or the } \\
\text { revitalisation of } \\
\text { abandoned and ruined } \\
\text { heritage. Valorisation } \\
\text { is conducted from the } \\
\text { conservational, } \\
\text { cultural, historical, } \\
\text { spatial, ambient, } \\
\text { architectural, aesthetic } \\
\text { and functional aspect. }\end{array}$ \\
\hline Criteria & Revitalization Criteria & Enhancement Criteria & $\begin{array}{l}\text { Criteria For New } \\
\text { Interventions }\end{array}$ \\
\hline
\end{tabular}




\begin{tabular}{|c|c|c|c|}
\hline & $\begin{array}{l}\text { Revitalization criteria } \\
\text { are determined when the } \\
\text { heritage in question is in } \\
\text { poor condition, has no } \\
\text { purpose and is not in } \\
\text { use, so it needs to be } \\
\text { repurposed and given } \\
\text { new life. } \\
\text { Preferably, the renewal } \\
\text { should ensure that the } \\
\text { level of authenticity is } \\
\text { kept as high as possible, } \\
\text { i.e. that historic } \\
\text { structures and other } \\
\text { remains are preserved, } \\
\text { just like essential } \\
\text { identity features, and } \\
\text { that modern } \\
\text { interventions provide the } \\
\text { revival and } \\
\text { reinterpretation of the } \\
\text { past environment. }\end{array}$ & $\begin{array}{l}\text { Criteria for heritage } \\
\text { enhancement are determined } \\
\text { when the heritage in } \\
\text { question is in good } \\
\text { condition, is living and is } \\
\text { being used, but needs } \\
\text { improvement. These criteria } \\
\text { must ensure the preservation } \\
\text { of the most valuable identity } \\
\text { features of heritage and } \\
\text { prevent any sort of cultural } \\
\text { heritage devaluation or } \\
\text { destruction. Enhancement } \\
\text { refers to conservation and } \\
\text { architectural enhancement, } \\
\text { as well as the technological } \\
\text { enhancement of buildings } \\
\text { and their adaptation to } \\
\text { modern standards and } \\
\text { needs. } \\
\text { During these procedures, the } \\
\text { usual technical standards } \\
\text { must be adjusted to respect } \\
\text { the features and values of } \\
\text { the cultural heritage and to } \\
\text { find a balance between the } \\
\text { requirements and } \\
\text { possibilities. }\end{array}$ & $\begin{array}{l}\text { Criteria for new } \\
\text { interventions in } \\
\text { heritage, both those } \\
\text { for enhancement and } \\
\text { revitalization, are } \\
\text { based on the character } \\
\text { of the heritage (its } \\
\text { identity features) and } \\
\text { its value and enrich } \\
\text { heritage with a new } \\
\text { contemporary } \\
\text { contribution. There is } \\
\text { a difference between } \\
\text { general criteria used in } \\
\text { numerous cases and } \\
\text { specific criteria that } \\
\text { originate from the } \\
\text { factors of identity, } \\
\text { influence and value. } \\
\text { By changing the } \\
\text { criteria, objectivity } \\
\text { increases, and } \\
\text { subjectivity } \\
\text { predominantly } \\
\text { decreases when } \\
\text { deciding on new } \\
\text { interventions in } \\
\text { heritage areas. }\end{array}$ \\
\hline & \multicolumn{3}{|c|}{ Heritage Revival and Enhancement Models } \\
\hline Models & \multicolumn{3}{|c|}{$\begin{array}{l}\text { Models of heritage revival and enhancement are both determined in accordance } \\
\text { with the factors of identity, influence and value, and in harmony with the criteria } \\
\text { for new interventions. To establish potentially applicable models, it is advisable } \\
\text { to use a comparative analysis of the selected relevant examples (case study) to } \\
\text { determine the historical and modern models in similar situations, which will } \\
\text { guarantee the selection of the best model for a specific case. The models offered } \\
\text { will present a creative approach to solving the revitalisation problem because all } \\
\text { heritage cases are different due to their factors of identify, influence and value } \\
\text { that make each case unique. Whenever possible, it is recommended to apply the } \\
\text { models of integrative planning which allow for sustainable development in the } \\
\text { long run. The central interest is the interaction between the preservation and } \\
\text { enhancement of the cultural heritage and the development strategy of the space. }\end{array}$} \\
\hline
\end{tabular}

Note: Adapted from chapter 30, Quality of Life in Urban Landscapes: In Search of a Decision Support System, 2018. 
Overall, the literature review demonstrates that the theory and practice of urban planning, urbanism, and heritage are largely intertwined. Colavitti (2018) notes, in "urban planning's culture...the importance of historical-cultural heritage is no longer identifiable with the big monuments and cities only, but must be extended to the historical and landscape fabric of the whole territory"(p. 78). Further urban planning:

must be predictive, and predicting the future impacts of planning interventions requires (a) theoretical understanding of the processes that shape the making of spaces and places. Thus, planners need theory and, while they may be relying on theory that is internalized, implicit and unexamined, it is present nonetheless. (Fainstein \& DeFilippis, 2016, p. 3)

Lastly, the interdisciplinary characteristic of urbanism includes "urbanist, spatial, landscape, architectural, cultural and historical, conservation, technical and infrastructural, legal, economic, and other views on space"(Obad Šćitaroci \& Bojanić Obad Šćitaroci, 2019, p. 6). Urbanism also refers to a "dynamic approach" (Obad Šćitaroci \& Bojanić Obad Š́́itaroci, 2019, p. 8) of heritage urbanism that "enhances spatial development, suitable for amendments and enhancements”(Obad Šćitaroci \& Bojanić Obad Šćitaroci, 2019, p. 8), which are important components in the argument of HCDs. 


\section{Chapter Three: History of Urban Planning in Toronto and LPAT}

\subsection{Overview of Urban Planning in Toronto}

Planning and heritage scholar Robert Shipley et al. notes that "Canadian planning law and traditions are largely based on the British model, (which is linked to) the Town and Country Planning Act of 1947 '(Robert Shipley et al., 2011, p. 612). With that said, it is also important to recognize that because planning is linked to Eurocentric modes of understanding, then one must acknowledge that "cities have historically been critical to the establishment of the colonial state and continue to be the key sites for the reproduction of modern colonial relations" (Walker \& Belanger, 2013,p.195).

Before the City of Toronto was considered the Town of York, it was [and continues to be] the traditional territory of many nations. The land recognized by Indigenous peoples as "turtle island... is covered by the Dish With One Spoon Wampum Belt Covenant, an agreement between the Anishinabeg and Haudenosaunee allied nations to peaceably share and care for the lands around the Great Lakes"(City of Toronto, 2019a, p. 9). In addition to the Anishinabeg and Haudenosaunee nations, other nations represented in the territory are "Mississauga of the Credit, the Chippewa, and the Wendat peoples" (Indigenous Affairs Office-City of Toronto, 2019, para. 1). The City of Toronto is currently home to many diverse First Nations, Inuit and Métis peoples"(Indigenous Affairs Office-City of Toronto, 2019, para. 1) and is "covered by Treaty 13, signed with the Mississauga of the Credit, and the Williams Treaties, (which cover lands east of

Woodbine Avenue such as Scarborough) [and was] signed by multiple Mississaugas and Chippewa Bands" (Indigenous Affairs Office-City of Toronto, 2019, para. 3). As Walker and Belanger (2013) note, to decolonize "our approaches to urban planning and policy requires that we consciously decenter 'Western' authority over procedural and substantive knowledge that 
dominate and presume cultural neutrality in the physical and aesthetic, social, cultural, economic, and political production of space"(p. 196). Further, "ensuring mechanisms exist for recognizing and implementing self-determination is considered a basis for constructive engagement between a municipal government and Aboriginal communities”(Walker \& Belanger, 2013, p. 200). The Town of York was "founded a decade after the end of the American War of Independence as a colonial outpost to promote settlement and to protect British interests in what was then known as Upper Canada"(Relph, 2014, p. Preface). In the Town of York, it:

took decades of hard work to push back the forest and to make streets, and unlike towns on the American urban frontier, which self-consciously based their architecture and plans on Philadelphia and New York, there were no national urban models to admire and follow. (Relph, 2014, p. 31)

With the rise of the "electrified streetcar in 1890"(Relph, 2014, p. 39), there is said to be an "unplanned suburbs which occurred in the days before building codes and planning regulations, self-building was the least expensive way for families to obtain homes"(Relph, 2014, p. 39). Early areas of Toronto consisted of "treeless shantytowns, and though their streets followed the grid, the houses had idiosyncratic and humble designs, with irregular setbacks and orientations"(Relph, 2014, p. 40). In the early years of the nineteenth century:

a major fire destroyed several blocks in the city center, making substantial reconstruction necessary, and the first modest office skyscrapers, an impressive new railway station (Union Station), and an adjacent railway hotel (the Royal York Hotel) were built in the following two decades and remain important landmarks. (Relph, 2014, p. 41)

Fast forward to the early 1980s, a little more than a decade before Toronto's 1998 amalgamation, "it became more evident that urban reform in the (inner) City of Toronto 
represented a form of regulating rather than opposing the transformation of Toronto from the core city"(Kipfer \& Keil, 2002, p. 238). A "few improvements were made in the public transit system, the structure of government remained ossified, and social housing production slowed" (Bourne, 2001, p. 35). The decade also signalled "economic transformation as well as an increase level of immigration,(which) maintained population growth"(Bourne, 2001, p. 35). By the end of the decade, the "Liberal government of David Peterson formed the Office of the Greater Toronto Area (OGTA), which in 1990, commissioned a major study by the Toronto consulting firm IBI Group on how the region's future urban growth might be shaped"(White, 2007, p. 37).

With the difficulties of the 1980s in the rear-view, it was the "social-democratic New Democratic provincial government (1990-1995) (and) former Toronto Mayor John Sewell who spearheaded a modest reform of planning legislation" (Kipfer \& Keil, 2002, p. 240). This reform "would have encouraged urban intensification and limits to sprawl" (Kipfer \& Keil, 2002, p. 240). There was also a focus on the merging of planning and the environment displayed in "the 'City Plan of 1991' and the Metro Toronto 'Livable City Plan of 1992' which proposed orienting planning along the waterfront towards a symbiosis of economic, environmental, and social goals”(Kipfer \& Keil, 2002, p. 240).

The 1998 amalgamation of Toronto, signalled the "aggressive neoliberalism of the new provincial Conservative regime elected in 1995"(Kipfer \& Keil, 2002, p. 240) who dismantled “the NDP's unified planning regime in the Greater Toronto Area (and) deregulated urban planning and development controls"(Kipfer \& Keil, 2002, p. 241). Scholars note that city planning in the new City of Toronto took on a heavy burden due to the "Federal and Provincial Governments underfunding of the local planning department (which had) faced the biggest staff and budget cut of all amalgamating departments (15\% in 1998 and 1999)"(Kipfer \& Keil, 2002, 
p. 244). In addition, as a money-saving tactic, the Harris Conservative government initiated a Smart Growth program for Ontario, which "was a rather loosely defined notion that emerged in the United States in the 1990s (with)... fairly standard planning and growth management policies to advance the public interest'(White, 2007, p. 42). White also refers to a 2003 final report from the Smart Growth Secretariat, suggesting that the government planning tactic "was long on visions and ideals, and short on realistic strategies"(White, 2007, p. 42).

After the exit of the PC Ontario party from governing Ontario, the impact on urban planning was significant, but more importantly, "the ground was prepared for another government, one more inclined towards intervention, to develop a regional plan. It is a surprising legacy for such an anti-government government'(White, 2007, p. 42). With the election of a “more centrist Liberal government in 2003”(Filion \& Kramer, 2011, p. 205), came an incentive to pick up the baton. So, the government adopted "a smart-growth- inspired strategy, the Growth Plan, providing the legal context for urban development changes in an extended region centred on Toronto"(Filion \& Kramer, 2011, p. 205). Following the creation of the Growth Plan, there was also a flood of programs, which included:

an extensive regional Greenbelt, the passage of the Places to Grow Act in 2005, and then, in June 2006, the release of the Growth Plan for the Greater Golden Horseshoe, the first regional plan for the Toronto Metropolitan Region in more than 30 years. (White, 2007, p. 44).

Overall, the Provincial government's decisions, particularly the Growth plan was supported by Toronto's local government, to a certain extent, because in 2003, elected Mayor David Miller, is said to have "fully subscribed to an official plan that favours intensification and public transit development"(Filion \& Kramer, 2011, p. 206). Sorenson notes that by the time 
Millers era in office had ended, "little transit development had taken place due to a protracted planning process and slow release of provincial funds"(Filion \& Kramer, 2011, p. 206).

In 2010, Miller's administration was the target of than Mayoral candidate, businessman and long-time councillor, Rob Ford, "who ran on a cost-cutting platform”(Filion \& Kramer, 2011, p. 206) and was elected as Mayor. Mayor Ford was "committed to stopping a presumed 'war on the car' by ending the allocation of road space to bicycle lanes and LRTs'(Hume, 2011, Filion \& Kramer, 2011, p. 206). He further cut "the most unpopular tax (council had) ever seen" (CBC News, 2010, 1. 7), by ending both the " $\$ 60$ vehicle registration and $\$ 30$ motorcycle fee [which] became a hot-button issue during the election"(CBC News, 2010, 1. 9).

In 2010, the Organization for Economic Co-operation and Development (OECD) reported that Toronto was "lagging (in) productivity, below the mean for the metropolitan regions that the OECD monitors"(Relph, 2014, p. 127). They further suggest that it was due to a "combination of poor infrastructure, especially regional transportation, and a lack of unified government"(Relph, 2014, p. 127). The solution to this was "competitiveness" and by 2011, the City of Toronto was widely considered a "crane city"(Jackson, 2018, p. 147). City planners noted that "there were more cranes on Toronto's skyline than the three biggest USA cities combined"(Jackson, 2018, p. 147). Further, the "GTA's [Greater Toronto Area] population stood at 6.054 million"(Jackson, 2018, p. 147), but with the rash of development came heightened concerns.

City planners noted that among the concerns was "worsening freeway gridlock; a general despair about local politics and the sense that planning in Toronto was losing its sense of purpose"(Jackson, 2018, p. 147). By the end of 2012, it said that "4.7 million square feet of office space were built... driven because companies want[ed] to be located in the downtown 
where their employees live"(Freeman, 2015, p. 28). The development continued in "the first quarter of 2014, 2,496 high-rise condos sold in the GTA and only 1,631 low-rise"(Freeman, 2015, p. 28). In late 2014, businessman John Tory was elected as Mayor, his election promise of a Smart Track transit plan, which consisted of a "downtown relief line”(Freeman, 2015, p. 75), never materialized. Still, there was a "modest network of bike lanes"(Freeman, 2015, p. 89). It is important to clarify that although the development was happening all over the city, the strongest was in Toronto's downtown core.

In addition, for years in the inner suburbs (North York, Etobicoke/York, and Scarborough), there were few signs of rapid development. Still, areas that do have development are "expensive and (largely) geared to those with high income"(Freeman, 2015, p. 124). Freeman further notes that "thirty thousand new immigrants a year are settling in the inner suburbs, and the housing that they can afford is very limited"(Freeman, 2015, p. 124). He continues by suggesting that in the past, "waves of immigrants that settled in Toronto, lived close to the downtown (core) because that was where they could find inexpensive housing"(Freeman, 2015, p. 124), and this has largely changed. He attributes the inconsistency in inner suburban development and planning to the development industry and planning policies. Freeman concludes that these areas "need to be redesigned to create hubs, or village centers, with shops, public services, offices, and other places of work"(Freeman, 2015, p. 126).

In 2018, in an expected but ironic turn, particularly when discussing planning in Toronto, Mayor John Tory won his second term defeating "former chief city planner Jennifer Keesmaat ...in a 10-month campaign that had him lead[ing] in the opinion polls from start to finish"(Shum, 2018, 1. 2). Mayor Tory pledged to hold up his commitment to redesigned his "smart track plan, [while creating] 40,000 affordable housing units over 12 years by developing 
city-owned land"(Shum, 2018, 1. 13). Mayor Tory was elected amongst political strife as "Ontario Premier Doug Ford passed legislation midway through the municipal election campaign, cutting the number of Toronto council seats to 25, from 47"(The Canadian Press, 2020, 1. 2).

In July 2019, Mayor John Tory and Deputy Mayor and City Councillor Ana Bailao passed a motion to "open the door to different kinds of development across the city (which) represents a critical step in reshaping Toronto into the denser, more walkable, more transitoriented city that it will, and must, become" (Bozikovic, 2019, 1. 6). The passage of Bill 108, the More Homes, More Choice Act, also occurred in the same year. This Act significantly “undermines the City's ability to ensure that 'growth pays for growth' through substantive amendments to Sections 37 and 42 of the Planning Act, and the Development Charges Act "(City Manager and Chief Planner and Executive Director, City Planning, 2019, p. 1). In addition, it also affects "the City's finances; the ability to secure parkland; the capacity to provide community facilities; and on the evaluation of development applications that would afford appropriate opportunities for public consultation"(City Manager and Chief Planner and Executive Director, City Planning, 2019, p. 1).

In 2020, the amendments under Bill 108 are scheduled to take effect. The cut to the size of City council will be under review because the Supreme Court of Canada has agreed to "look at the legality of Ontario's decision to slash the size of Toronto's City council'"(The Canadian Press, 2020, 1. 3). The Supreme Court's decision could have a positive or negative effect on future planning in Toronto. Still, time will tell, as this will be one of the many obstacles facing the city. A more significant issue is the lingering effect of the social, economic, and political destruction that COVID-19 has thrown towards the city, country, and the world. The pandemic is 
noted to have caused a " $\$ 1.5$-billion [dollar] shortfall by the end of the year: an estimated $\$ 938$ million directly related to [the first] three-months [of the] lockdown and $\$ 590$ million during a six-month recovery phase, as restrictions ease"(Pagliaro, 2020, 1. 7). Further, the recent bailout commitment of "549.8 million"(Elliott, 2020, 1. 1) from the "provincial government with support by the federal government, through the Safe Restart agreement"(Elliott, 2020, 1. 1) only covers "41 per cent of the total amount Toronto needs to fill its projected \$1.35-billion year-end shortfall. The rest is TBD [To be announced]"(Elliott, 2020, 1. 1).

The pandemic has also affected construction timelines for housing, cycling infrastructure, transit, and waterfront development. Regarding transit, a Toronto Star newspaper article noted that in the:

short-term projects are likely to be delayed by health precautions that prevent construction crews from working normally, and in the long-term, could be affected by disruptions to global construction supply chains and government funding constraints caused by the economic downturn. (Spurr, 2020a, 1. 6)

The article continues by suggesting that the "lines already under construction, like the Eglinton Crosstown LRT, as well as those still in the planning stages, like the Ontario Line and other projects in the Progressive Conservative government's $\$ 28.5$ billion [dollar] network expansion plan"(Spurr, 2020a, 1. 2), will also be affected. One of the major economic-related casualties of the pandemic is the loss of Toronto's first Smart City. Considered "one of the most ambitious 'smart city' projects on the continent" (O'Kane, 2020, 1. 1), the "proposed 12-acre, technologylaced community [was going] to be built on old industrial land on Toronto's waterfront" (O’Kane, 2020, 1. 1). 
In regards to housing, the pandemic has heightened the visibility of "Toronto's one percent vacancy rate"(Kopun, 2020a, 1. 12) and put a dent into the physical construction targets in the Mayor's "HousingTO 2020-2030 Action Plan, which calls for the city to approve 40,000 new affordable rental homes, including 1,000 modular homes" (Kopun, 2020b, 1. 13). The pandemic has proven to create the attention needed to bring light to the under-housed population in Toronto, causing the City to move on identifying "two sites to build modular homes...to move the first 100 people into them as early as the Fall (2020)"(Kopun, 2020b, 1. 1). The collection of these actions are central to the rapid development of the City, especially with "most policymakers and residents [favouring] intensification — which is more sustainable and conducive to complete communities than sprawl" (McKeen, 2018, 1. 10).

On another positive note, the City of Toronto has approved the "rapid installations [of] cycling infrastructure, using temporary materials and minimal change to the street design" (Spurr, 2020b, 1. 1). Mayor Tory "notes that the quick expansion of the bike network would get more people cycling during the crisis and deliver economic and public health benefits"(Spurr, 2020b, 1. 3). Overall, throughout the history of planning in the City of Toronto, one can determine that people's needs should be the center of the divide between power and politics. Further, it's only when planning combats the problems of the people is when the city planning practices will progress beyond its market-driven tendencies. In the next section, I will discuss the events leading to the City of Toronto's 1998 amalgamation and how these changes created a politicalized divide between pre and post amalgamation areas in the City.

\subsection{The Role of the Mega City-Toronto Amalgamation of 1998}

During the time of amalgamation in Toronto, there "was a double-spell of economic crisis and political reaction... the booming economy of the 1980s had collapsed, both industrial 
restructuring and an unprecedented real estate crisis took their toll on workers and communities..."(Keil, 2000, p. 758). The City of Toronto's double spell was noted to be:

reinforced by the effects of continental free trade, anti-inflationary monetary policies, and the deconstruction and devolution of the Canadian welfare state, the recession accelerated polarizing and uneven urban restructuring, undermined local and provincial initiatives for urban intensification, regional transit integration, and social housing. (Kipfer and Keil, 2002, p. 240)

The amalgamation of the former "Municipality of Metropolitan Toronto or 'Metro Toronto', into the City of Toronto by the Ontario government in 1998 was forced" (Bramwell \& Wolfe, 2014, p. 64). Then Premier Mike Harris and "his ‘common sense revolution' proceeded to consolidate Metropolitan Toronto rather than the Greater Toronto area” (Kipfer \& Keil, 2002, p. 241). Further, the public:

support for Ontario's neoliberal provincial government in the exurban communities of Toronto was the basis for a truly 'suburban ambush' (to paraphrase Toronto ex-Mayor John Sewell) on inner-city autonomy and brought the inner city into the direct political reach of suburban politicians and their agendas. (Keil, 2000, p. 758)

The transformation of the:

two-tier system of municipal government ...composed of an upper-tier municipality, the Municipality of Metropolitan Toronto, and six lower-tier municipalities (including) the City of Toronto, the City of North York, the City of Etobicoke, the City of Scarborough, the City of York, and the Borough of East York [is still debated today].(Moore, 2013, p. 209) 
Before a hint of amalgamation was in the air, tension brewed in Toronto with the debate between "the Old Guard (who) supported a pro-development agenda (and the) the Reform Group, (who) wanted controls on development" (Freeman, 2015, p. 160). The:

Reform Group came to power in 1971 with the election of David Crombie as Mayor. He was supported by reform councillors like John Sewell, Colin Vaughan, Allan Sparrow, and others. They created the most innovative municipal government ever seen in Toronto. (Freeman, 2015, p. 160)

Further, the 1970s were noted as the "heyday of progressive politics in Toronto" (Freeman, 2015, p. 161), with prevalent phrases like the "city that works"(Kipfer \& Keil, 2002, p. 238) dominating discussion among “journalists and planners”(Kipfer \& Keil, 2002, p. 238). As time progressed, the famed city that works encountered a "double impasse"(Kipfer \& Keil, 2002, p. 238). The "Toronto-Centred Plan—a strategy to limit urban sprawl and extend regional governance to the exurbs"(Kipfer \& Keil, 2002, p. 238) was knocked down. While, "rational comprehensive planning hit a wall in the inner City of Toronto"(Kipfer \& Keil, 2002, p. 239), causing some wear and tear on the success of the City.

This wear and tear is said to have "fortified tensions and competitive pressures between the newly amalgamated City of Toronto (the 416 telephone area) and the exurban cities and regional municipalities (the 905 telephone area)"(Kipfer \& Keil, 2002, p. 239). Moreover, in the "early 1980s, it became more evident that urban reform in the (inner) City of Toronto represented a form of regulating rather than opposing the transformation of Toronto" (Kipfer \& Keil, 2002, p. 239). Keenan echoes Kipfer and Keil (2002) when he suggests that:

the suburban areas, more expensive to serve and built as shrines to social isolation - or, if you prefer, privacy - had always had higher taxes and lower levels of service, and they 
tended through the 1980 s to be whiter, more solidly middle-class and more conservative politically. (2013, Para.43)

Keenan goes on to note that the "demographic divide started opening up around the time of amalgamation (but the political identities) - conservative suburbs and left-leaning downtownwere firmly entrenched"(Keenan, 2013, Para.45). In the aftermath of amalgamation, the demographic divide caused an "identity crisis"(Keenan, 2013, Para.46) for the City. Toronto was largely considered to have taken the "high road of democratic discourse and local autonomy against an interventionist, authoritarian — and consolidationist — neoliberal provincial government"(Keil, 2000, p. 758). Yes, this identity crisis, coupled with Conservative policies, “triggered widespread resistance in Toronto and the rest of Ontario (with), citizen groups sprang up in downtown Toronto and the surrounding municipalities to protest amalgamation in 1997" (Kipfer \& Keil, 2002, p. 242). Protests from organizations like "Citizens for Local Democracy (C4D)"(Freeman, 2015, p. 162), and the recommendations from The Greater Toronto GTA Task Force Report. The report recommended keeping "the lower-tier municipalities in place and create a second-tier government that stretched across the entire GTA"(Freeman, 2015, p. 161). These two initiatives were not strong enough for the amalgamation machine to be derailed and so the Megacity prevailed.

A staggering "one hundred and twenty councillors and six Mayors were reduced to fortyfour councillors and one Mayor who were to govern a city of 2.3 million” people (Freeman, 2015, p. 161). Freeman (2015) noted that the "Megacity was an attempt by the Harris Conservatives to control the democratic process of local government in Toronto and stamp out the influence of the downtown progressives" (p. 161). Creating the Megacity was ultimately "a competitiveness strategy that, in broad strokes, had the tacit support of many globalized business 
interests in the city even as it worked as an irritant to middle class reform fragments of the existing growth machine coalition" (Kipfer \& Keil, 2002, p. 232). The takeaway from this period is that "people want and need local control over their communities" (Freeman, 2015, p. 179).

\subsection{The City of Toronto's Official Plan and HCDs}

The City of Toronto Official Plan is "the principal vehicle for implementing provincial policy and legislation”(M. L. MacDonald et al., 2019, p. 26). It was “adopted by City Council November 2002 and approved, in part, with modifications by the Ontario Municipal Board/Local Planning Appeal Tribunal"(Lintern, 2019, p. A-7). The Official Plan contains seven Chapters and is based on four principles, "diversity and opportunity; beauty; connectivity; and leadership and stewardship"(Lintern, 2019, p. 1-2). The City notes that the "Official Plan is about making the right choices and shaping Toronto's collective future...getting the fundamentals right (and) having a clear vision for the City - grounded in durable principles that assure a successful future" (Lintern, 2019, p. 1-1). Each Chapter "consists of the policies, maps and schedules (as well as) non-policy textual commentary (unshaded text and sidebars) to make the Official Plan more accessible"(Lintern, 2019, p. 1-1). In addition, the:

plan is about the big picture; it spells out a clear direction for Toronto. It is the road map to our future, providing the basis for building a city-wide consensus around change and intent of the policies more readily understandable. (Lintern, 2019, p. 1-7)

Concerning heritage conservation, the Official Plan "contains a number of policies related to properties on the City's Heritage Register and properties adjacent to them, as well as the protection of areas of archaeological potential"'(Acting Chief Planner and Executive Director, City of Toronto Planning Division, 2017, p. 6). 
Chapter 3 (Section 3.1.5) of the Official Plan covers heritage conservation, and this section consists of 53 policies. The City notes that in the introductory section that heritage conservation alines with the "City's goal to integrate the significant achievements of our people, their history, our landmarks, and our neighbourhoods into a shared sense of place and belonging for its inhabitants"(Lintern, 2019, p. 3-10). The "Official Plan provides direction on how HCD studies and plans will be conducted and notes the protocols and provisions that will be included"(Acting Chief Planner and Executive Director, City of Toronto Planning Division, 2017, p. 5). HCDs are covered within policy 3.1.5-30 to 33; but of significant importance is policy 3.1.5-31, which states that Heritage Conservation District studies and plans will, among other things:

a) Be conducted in accordance with Council adopted guidelines and terms of reference;

b) Include protocols for amendment and periodic review; and

c) Include provisions addressing the relationship between the Heritage Conservation District Plan and the Official Plan and provincial policy within the context of the Heritage Conservation District Plan's directions for conserving the cultural heritage values and character of the Heritage Conservation District...(Lintern, 2019, p. 3-10) These “policies speak directly to Ontario's Regulation 9/06 and the Standards and Guidelines for the Conservation of Historic Places in Canada" (City of Toronto-Chief Planner and Executive Director, City Planning Division, 2019, p. 24). Further, the PPS sets "the foundation for the City's Official Plan policy (and recently) the amendments of Bill 108, have forced City council to focus on the alignment of PPS language and the City's priorities and policy directions"(Chief Planner and Executive Director, City Planning, 2020, p. 10). Therefore, "the effects of these 
changes on the policies of HCDs are largely unknown but assumed to have consequence"(Chief Planner and Executive Director, City Planning, 2020, p. 10).

Overall, this chapter's goal was to demonstrate that planning in the City is a highly politicized undertaking that is further complicated by the intergovernmental nature of policies that govern the City. Further, the lingering effects of the 1998 amalgamation, and the division among key stakeholders, clearly shaped the Megacity planning systems. The City’s Official Plan's current iteration has a stronghold on the outlook and objectives of the City's heritage conservation policies and practices. Therefore, in the next chapter, I will examine the recent changes to Ontario's planning legislation and how these changes affect the City of Toronto's heritage conservation practices. 


\section{Chapter Four: Provincial Bodies and Legislation-Amendments, Anger and Awakening}

\subsection{The Local Planning Appeal Tribunal (LPAT) and HCDs}

The Ontario Municipal Board (OMB) was founded in "1906 ... (as the) Ontario Railway and Municipal Board (ORMB)" (Moore, 2013, p. 4). On "April $3^{\text {rd }}$, 2018, the OMB became the Local Planning Appeal Tribunal (LPAT)"(Leah Hansen, 2018, 1. 3). Historically, Ontario Railway Municipal Board or “ORMB's main purpose was to regulate municipal street railways in the province's rapidly growing cities. By the early 1930s, the purpose and name of the board ... had changed"(Moore, 2013, p. 4).

Currently, LAPT is considered an "adjudicative tribunal that hears cases in relation to a range of land use matters, heritage conservation and municipal governance"(Tribunals Ontario, 2020). Further, "the appeals that come before LPAT are identified through policies found in the Planning Act, Aggregate Act, Heritage Act, Municipal Act, Development Charges Act and Expropriations Act"(Tribunals Ontario, 2020, para. 1). In the City of Toronto, "council's planning decisions are subject to appeal to the Ontario Municipal Board, which functions as a powerful quasi-judicial appeal body for land-use planning”(Moore, 2013, p. 5). In addition, Moore (2013) continues suggesting that:

...the OMB can overturn Toronto City Council's decisions regarding development just as it can (make) the decisions (for) the province's smallest municipalities. Both the OMB's position as the final decision-maker on development and planning issues and the procedural requirements of appealing to the board may substantially shape and direct the politics of urban development in the City of Toronto. (p. 5)

In recent years, both the public and Toronto's City Council have had multiple complaints about the OMB's past decision-making powers. These complaints reached a boiling point in 
2016 when the province launched a review. The review process was "spearheaded by Yasir Naqvi, former Ontario attorney general and MPP for Ottawa Centre"(Leah Hansen, 2018, 1. 6). In May 2017, the provincial government "introduced Bill 139 - the Building Better Communities and Conserving Watersheds Act, 2017 (introducing) new legislation to replace the Ontario Municipal Board with the Local Planning Appeal Tribunal, and make amendments to existing legislation"(Ontario Ministry of Municipal Affairs and Housing, 2017, sec. Decision on policy).

The introduction of the Act came with public consultations on the proposal, which lasted for “75 Days, from October 05 to December 19, 2016”(Ontario Ministry of Municipal Affairs and Housing, 2017, sec. Comment(s) received on the proposal). The Ministry of Municipal Affairs and the Ministry of the Attorney General received over " 1,100 written submissions... in response to possible changes outlined in the government's public consultation Document" (Ontario Ministry of Municipal Affairs and Housing, 2017, sec. Effects of consultation). Further, "over 700 participants took part in the consultation across the twelve regional town hall meetings"(Ontario Ministry of Municipal Affairs and Housing, 2017, sec. Effects of consultation). The OMB's transition to LPAT has affected citizens and municipalities in different ways, and this is displayed in Table 2.

\section{Table 2}

$O M B$ vs LPAT

\section{OMB}

The OMB would hear arguments from both sides and make decisions based on what it believed to be the "best" planning outcome, at times overruling the decisions of local councils.

There were few supports for ordinary citizens, who complained that the costs of participating in matters before the OMB was prohibitive.

\section{LPAT}

The LPAT will answer a simple "yes or no" legal test - does the proposal follow the city's official planning rules? If not, the matter will be sent back to municipal councils to issue another decision. The tribunal will not make planning decisions itself.

The establishment of the Local Planning Appeal Support Centre will provide legal and planning help for both citizens and community associations. 
The OMB held de novo (from the beginning) hearings where it would consider the development proposal as though it had never been considered before.

The OMB sometimes served as a "scapegoat" for council to approve projects that catered to the wants of developers, Leiper said.
All hearings will consider only the decision made by local councils — rather than starting from scratch.

Note: Adapted from the 2018 CBC online article entitled The Ontario Municipal Board Will Soon Be No More. Here's What That Means for You by Leah Hansen.

Largely the changes "would not allow appeals on major planning documents, such as municipal official plans, and would restrict appeals of neighbourhood plans to within two years after they come into effect"(Chianello, 2017, 1. 13). In addition, “community groups access to planning and legal help during an appeal"(Chianello, 2017, 1. 18) would be limited and "major planning decisions made by city councils can be implemented much more quickly"(Chianello, 2017). LPAT is also part of Ontario Land Tribunals (OLT), which "brings together five Ontario tribunals and boards which adjudicate matters related to land use planning, environmental and heritage protection, land valuation and other matters"(Ontario Land Tribunals, 2020a, 1. 1).

Regarding heritage preservation and changes from the OMB to LPAT, a former senior policy advisor with the Provincial Culture Ministry, Dan Schneider, suggests that it's “consequential”(Schneider, 2017, 1. 35). According to Schneider, most processes relating to heritage, such as "appeals to the OMB/LPAT, on heritage conservation districts, refusals to approve building demolition, etc., are all untouched"(Schneider, 2017, 1. 36). On the upside, Schneider considered the creation of the Local Planning Appeal Support Centre as a "good thing"(Schneider, 2017, n. 2). However, in February 2019, the Ford government closed the door of the center, citing that it was a "difficult decision (but necessary because) demand for the centre's services [had] been low, averaging just three enquiries per day"(Crawley, 2019, 1. 11). 
On the other hand, Ontario's official opposition political party suggested that "the decision was 'stacking the deck' against ordinary people in favour of powerful developers” (Crawley, 2019, 1. 16). LPAT members are mandated to adhere to the Ontario Heritage Act's policies and guidelines and "assumes all designation-related responsibilities"(Schneider, 2020a, 1. 9). Further, Schneider notes that "in addition to hearing demolition appeals as at present, the Tribunal will hear alteration appeals"(2020, 1. 9). The Tribunal can "also hear appeals from municipal decisions to designate individual properties under Part IV of the OHA"(Schneider, 2020, 1.10). The OHA "gives municipalities and the provincial government (the) powers to preserve the heritage of Ontario (which includes) ...cultural heritage properties and archaeological sites"(Ontario Land Tribunals, 2020c, 1. 2). In addition, the "legislation also mandates ...the Conservation Review Board [CRB]"(Ontario Land Tribunals, 2020c, 1. 2). The CRB was created in 1975 under section III of the Ontario Heritage Act and is defined as an: adjudicative tribunal that ...considers a number of matters such as; the proposed designation of a property as having cultural heritage value or interest; applications for the repeal of a by-law on a specific property; applications related to the alteration of a property covered by a by-law; and, matters related to archaeological licensing. (Ontario Land Tribunals, 2020b, sec. CRB Role)

As an adjudicative tribunal, the CRB:

conducts proceedings on matters that are referred, which includes both pre-hearing conferences to explore the potential of settlement, as well as formal hearings to hear evidence and arguments to best enable the CRB to make recommendations to the final decision-making power for that particular case. (Ontario Land Tribunals, 2020b, sec. CRB History and Jurisdiction) 
In "2005 changes to the Act gave the CRB additional responsibilities ... and facilitated the cross-appointment of CRB Members to Local Planning Appeal Tribunal (LPAT) Panels hearing certain appeals under the act"(Ontario Land Tribunals, 2020b, sec. CRB History and Jurisdiction). In recent years, there has been concern in the heritage preservation community that LPAT members would have their hands full with the extent of their heritage preservation responsibilities when compared to the $\mathrm{CRB}$, which "will soon fade to black as the Local Planning Appeal Tribunal takes over its role"(Schneider, 2020, 1. 8).

All things considered, the concerns are valid because, as Schneider suggests, "in the past members of the CRB ...had a professional background and/or considerable experience in heritage conservation in the province"(Schneider, 2020a, 1. 13). LPAT members, on the other hand, do not; he points to the recruitment process of LPAT members noting that it is "not a good sign when only one out of the 33 current LPAT members appears to have any background in heritage"(Schneider, 2020, 1. 16). The solution is training, and Schneider notes that the "Tribunal urgently requires serious training in heritage conservation principles and practice — with respect to their new area of responsibility — cultural heritage evaluation in particular'(Schneider, 2020a, 1. 13).

Since LPAT members will have more responsibility in the near future, as changes to the Ontario Heritage Act (OHA) take place on "July 1, 2020"(Schneider, 2020, 1. 19), due to the passing of Bill 108, potential training will meet evolving needs. The Bill states that "instead of a review of a proposed designation by the Conservation Review Board, ... a binding appeal to the Local Planning Appeal Tribunal (will take place)" (Schneider, 2019, 1. 40). Therefore, local City councils will no longer have the last word on "a) what constitutes a cultural heritage property of 
value to the community, and b) the recognition and protection of (these) resources"(Schneider, 2019, 1. 41).

Overall, heritage-related matters are not the main agenda of LPAT, and cases on Heritage Conservation Districts occur far less than land use planning cases. Schneider suggests that matters of "heritage significance-to the exclusion of other interests and factors that do not bear on eligibility for designation demolition (as well as) issues in the context of a redevelopment proposal for the property"(Schneider, 2020a, 1. 21), will continue to arise. Therefore, changes need to be ensured, so there is an even playing field for heritage appeals in the Province.

\subsection{Provincial Policy Statement (PPS) 2020 and Heritage Conservation}

The Provincial Policy Statement (PPS) is a “key part of Ontario's policy-led planning system" (and) sets the policy foundation for regulating the development and use of land" (Ministry of Municipal Affairs and Housing, 2020, p. 1). It is "issued under the authority of Section 3 of the Planning Act and provides policy direction on matters of provincial interest related to land use planning and development"(City of Guelph, 2018, p. 10). Further, the PPS "promote(s) communities, economy, and environment and sets the policy foundation for regulating the development and use of land. Municipalities must align their policies with the direction of the PPS"(City of Guelph, 2018, p. 10).

Further, the PPS "also supports the provincial goal to enhance the quality of life for all Ontarians and improved land use planning and management, which contributes to a more effective and efficient land use planning system"(Ministry of Municipal Affairs and Housing, 2020, p. 1). The preamble of the current PPS notes that the "province recognizes the importance of consulting with Aboriginal communities on planning matters that may affect their section 35 Aboriginal or treaty rights"(Ministry of Municipal Affairs and Housing, 2020, p. 5). Through the 
application of the PPS, the Province aims to "build constructive, cooperative relationships through meaningful engagement with Indigenous communities to facilitate knowledge-sharing in land use planning processes and inform decision-making"(Ministry of Municipal Affairs and Housing, 2020, p. 1).

Over the years, there have been several amendments to the Provincial Policy Statement (PPS), with the first PPS being released in 1996, then 2005 and 2014. In "July 2019, the Provincial government released proposed changes to the Provincial Policy Statement (PPS), in support of the 'More Homes, More Choice: Ontario's Housing Supply Action Plan' ”(Chief Planner and Executive Director, City Planning, 2020, p. 9). As of May 1st, 2020, the current PPS replaced the April 2014 PPS. Recent changes to cultural heritage policies due to the PPS 2020 amendments have been defined as "minor"(Schneider, 2020b, 1. 3). Overall the changes "clarify and simplify existing provisions while in some cases extending the application of the policies" (Schneider, 2020b, 1. 3).

It is important to note that section 2.6 of the PPS has displayed "broad-level policies related to cultural heritage and archaeological resources"(City of Guelph, 2018). Further, "no changes have been made to section 2.6, which encompasses five policies (and) policies in [the subsection] 2.6.1, and its companion, 2.6.2..."(Schneider, 2020b, sec. New 2.6.5 says). There have been minor changes to policy 2.6 .5 on considering Indigenous interests. The new changes are to "explicitly require engagement with Indigenous communities, as part of a consideration of their interests, when undertaking a broad range of conservation activities"(Schneider, 2020b, sec. New 2.6.5 says). Other slight changes have occurred to the "definition of built heritage resource, conserved, cultural heritage landscape... heritage attributes and [the notion of] 'significants' 
"(Schneider, 2020b, sec.Things to note). Among the five policies, two key policies have influenced heritage conservation.

This includes policy 2.6.1, which suggests that "significant built heritage

resources and significant cultural heritage landscapes shall be conserved"(Schneider, 2020b, sec. Changes to section 2.6 "Cultural Heritage and Archaeology"). Section 2.6.2 states that “development and site alteration shall not be permitted on lands containing archaeological resources or areas of archaeological potential unless significant archaeological resources have been conserved"(Ministry of Municipal Affairs and Housing, 2020, p. 31).

Aside from the changes to the cultural policies mentioned, the PPS 2020 changes overall are "positive, as they provide more certainty around land development in Ontario... (and) provides both municipalities and developers with various tools to create some degree of flexibility in the land development process" (What's Changing? The Provincial Policy Statement, 2020, 2020, p. 3).

\subsection{Bill 108, More Homes, More Choice Act, 2019}

Bill 108 was introduced in May 2019, and many municipalities and cultural organizations at the time were opposed to the sweeping changes that Bill 108 would cause. The Bill is said to amend " 13 different pieces of legislation, including the Planning Act and the Development Charges Act" (City of Toronto, 2019d, para. 1). The "province has stated that the objective of Bill 108 is to increase housing supply in Ontario" (City of Toronto, 2019d, para. 1).

However, the opponents of Bill 108 note that the Bill "contains limited evidence that its central objectives, making it easier to bring housing to market and accelerating local planning decisions"(City of Toronto, 2019a, p.1). Also, specific to the City of Toronto, the Bill will: 
repeal the tools municipalities currently use to secure community infrastructure, including Section 37 (density bonusing), Section 42 (parkland dedication), Section 51.1 (parkland dedication - plan of subdivision), and the growth-related park and capital infrastructure component of Development Charges. These tools will be replaced by a single charge - the Community Benefits Charge (CBC). (Chief Planner and Executive Director, City Planning, 2020, p. 9)

The Community Benefits Charge (CBC) is important because it helps the City of Toronto to "recoup costs to meet growth-related community infrastructure and parkland demands"(Chief Planner and Executive Director, City Planning, 2020, p. 9). On May 14th, 2019, the City of Toronto released their preliminary comments on Bill 108 and outright opposed it. They noted, "Be it Hereby Resolved, that the City of Toronto opposes Bill 108 which in its current state will have negative consequences on community building and proper planning"(City of Toronto, 2019c, 1. 26). In addition, the City noted:

Be It Further Resolved that the City of Toronto calls upon the Government of Ontario to halt the legislative advancement of Bill 108 to enable fulsome consultation with Municipalities to ensure that its objectives for sound decision making for housing growth that meets local needs will be reasonably achieved. (City of Toronto, 2019c, 1. 27) On May 16th, 2019, Toronto City Councillor Mike Colle held a town hall meeting for Bill 108 for North York residents entitled The Return of the OMB. On May 27, 2019, a larger town hall was held by a group of Toronto Councillors entitled The OMB is Back, which was described as a "sold out crowd"(Heritage Toronto \& A. Bain, personal communication, May 30, 2019, para. 1). The May 27 meeting was initiated by Councillors Kristyn Wong-Tam, Josh Matlow and Gord Perks. Also, in attendance were Councillors Paula Fletcher, Mike Layton, Joe 
Cressy, Ana Bailão, Brad Bradford, and Toronto's Chief Planner Gregg Lintern. The meeting invited the public "to learn about how Bill 108 [would] impact their community and for the public to make their voices heard before it was too late"(Wong-Tam et al., 2019, para. 2).

Further, the City dedicated a section of its website to update the public and relevant stakeholders of the forthcoming changes due to Bill 108's impending passing. With the City's opposition expressed, Bill 108 received royal assent on June 6, 2019. Following this, the City's Planning Division noted that they would continue their "ongoing engagement with interdivisional and Provincial staff to advance Council priorities as draft regulations related to Bill 108 are released" (Chief Planner and Executive Director, City Planning, 2020, p. 11). They further noted, "that they will continue to be responsive to these changes and address emerging Provincial requirements in its planning frameworks"(Chief Planner and Executive Director, City Planning, 2020, p. 11).

\subsubsection{Bill 108 and its Impact on Heritage Conservation}

Bill 108 "will introduce some new requirements for designation by-laws but [does] not get into how evaluation is to be done"(Schneider, 2020b, sec. Changes to the definition of "significant"). Further, Bill 108 will "challenge the ability of the City to conserve its heritage resources within a complex land use planning environment"(City Manager and Chief Planner and Executive Director, City Planning, 2019,p.30). This is due to the fact that Bill 108 "provides for a back-end dispute model, rather than a ... front-end consultation"(City Manager and Chief Planner and Executive Director, City Planning, 2019, p. 30).

Heritage Toronto echoed the frustration of the City and heritage policy experts to their enewsletter subscribers, when they suggested that the OHA was enacted "on the central belief that local people through their city councillors [knew best] what was important to be identified, 
protected, and preserved in their communities"(Heritage Toronto \& A. Bain, personal communication, May 30, 2019, para. 2). However, now the power will be stripped from "local city council and planners" (Heritage Toronto \& A. Bain, personal communication, May 30, 2019, para. 2). The forthcoming amendments to the OHA are part of "Schedule 11"(Schneider, 2019a, sec. What should happen here?) [which is] expected to be enforced after July 1, 2020”(Schneider, 2020a, 1. 19).

To review, the Ontario Heritage Act (OHA) is "split into various sections, dealing with different types of cultural heritage resources (with) Part V of the Act (addressing) heritage conservation districts, and Part IV of the Act (addressing) the designation of individual properties"(City of Guelph, 2018, p. 12). The most important section that applies to HCDs is Section 41, which was previously referred to as Part V of the OHA and "enables municipalities to designate heritage conservation districts"(City of Guelph, 2018, p. 13).

When specifically looking at HCDs, Bill 108 "enables the Province to introduce principles in relation to Heritage Conservation Districts that Council will be required to consider when making decisions about designating a district, or when making decisions affecting the District"(City Manager and Chief Planner and Executive Director, City Planning, 2019, p.29). Bill 108 is further troubling for the City because the amendments, "may require revisions to the Council-approved guiding document for HCDs"(City Manager and Chief Planner and Executive Director, City Planning, 2019, p. 29), which is referred to at the beginning of this MRP. Questions remain around the breath of amendments that will occur if changes to the City's $H C D$ s in Toronto guiding Documents are initiated in the coming months, as well as the depth of the consultative process with the heritage sector and the public. As of March 2020, the province has not specifically provided direction on how to implement the [broad] changes that will occur 
due to Bill 108, but it is assumed that this will be explained in the "Ontario Heritage Tool Kit" (Schneider, 2019, 1. 38).

The Kit is "designed to help municipal councils, municipal staff, municipal heritage committees, land-use planners, heritage professionals, heritage organizations, property owners, and others understand the heritage conservation process in Ontario"(Ontario Ministry of Tourism, Culture and Sport, 2006, p. B). The legislative changes of Bill 108 came 14 years after the last change. Schneider suggests that "unlike the 2005 changes it is clear the current proposals do not enjoy wide acceptance by those who will be most affected by them, such (as) municipalities and heritage organizations"(Schneider, 2019a, 1. 13).

Further, the government is said to have only given a "one-month window to provide comments, after the legislation [had] already been introduced and where passage [was] anticipated within a week of the end of the comment period"(Schneider, 2019a, 1. 20). The current executive director of Heritage Toronto echoed Schneider's sentiments in 2019. In an enewsletter sent to Heritage Toronto subscribers, she expressed that it was "particularly difficult to comment on Bill 108 when details, including regulations and principles guiding the legislation, have not been made available"(Heritage Toronto \& A. Bain, personal communication, May 30, 2019, para. 2). Further, the only proposals that the government received were from "the development industry"(Schneider, 2019a, 1. 20).

Although Schneider agrees that changes to the Ontario Heritage Act are long overdue, he also feels that changes to the appeal process for Part IV designations missed the mark. He notes that these changes "further discourage heritage protection and conservation while doing nothing to improve or streamline the designation process"(Schneider, 2019a, 1. 55). Commenting on the effects of Bill 108 on heritage conservation, the City stated that "the proposed legislation will 
have significant impacts [particularly with] heritage conservation identification, notification, application processes, timelines and protection"(City of Toronto-Chief Planner and Executive Director, City Planning Division, 2019, p. 14).

Further, "under the proposed legislation, City Planning will need to take a more proactive approach to the inclusion of properties on the Heritage Register"(City of Toronto-Chief Planner and Executive Director, City Planning Division, 2019, p. 14). Overall, the City recommends that the Province "provide clarity on the relationship between the individual heritage values and attributes of properties within HCDs... particularly as it pertains to alterations"(City Manager and Chief Planner and Executive Director, City Planning, 2019, p. 32). They also suggest that the Province review changes to "section 27 and 29 of the OHA"(City Manager and Chief Planner and Executive Director, City Planning, 2019, p. 32).

The arguments presented in Chapter four have highlighted the challenges that come with provincial amendments to planning policy. Changes to planning legislation directly affect municipalities' ability to formulate policies around land use; therefore, direct consultation with municipalities is needed to mediate an intergovernmental conflict. Further, it's clear that the provincial government should always strive to hold consultations with the broad spectrum of stakeholders in the heritage sector as a lack of this can have far-reaching implications, which endanger the ability for municipalities to save both built and non-built forms of heritage. In Chapter five, I will present the current and historical precedent of HCDs in the City of Toronto and examine two case studies that represent the potential designation of HCDs in the inner suburb of Toronto, known as Scarborough. 


\section{Chapter Five: The Disproportionate Designation of Heritage Conservation Districts in}

\section{Toronto}

\subsection{Overview of Pre-existing HCDs and the Notion of the "Ideal District"}

The first Heritage Conservation District in the City of Toronto was a military district known as Fort York/Garrison, currently part of Ward 10 Spadina-Fort York. The second district was a residential district known as Wychwood Park, now part of Ward 12 Toronto- St. Paul's. Both HCDs were established in 1985, which means they were designated in pre-amalgamated Toronto. Following a nine-year pause came two more HCD designations in the 1990s (see Table 3). The first four HCDs set a precedent for the designation of districts in Toronto as they were central to the downtown core.

It's important to note that the last HCD of the first four designations in the City happened post-amalgamation but was still in the downtown core. Since 1999 the City has established seventeen more HCDs totalling 21 designated areas. Among the 21 HCDs I have tagged on the City of Toronto pre-existing 25 ward map (see Figure 3), there is only one HCD in North York, one in Etobicoke/York, and currently zero in Scarborough.

On this map, I have also identified the districts under appeal and the HCD studies being conducted. The four pending HCDs under appeal and the nine HCDs studies currently undertaken by the City of Toronto add to the argument of disproportionate designation (see Table 4 and Table 5). This is because the majority of the HCDs under appeal and study still represent wards of the downtown core, further demonstrating that the city's most recent intentions to introduce HCDs lack geographical diversity. 
Table 3

HCDs Designated by Toronto City Council

\begin{tabular}{|c|c|c|}
\hline $\begin{array}{l}\text { Heritage Conservation } \\
\text { Districts (Alphabetical) }\end{array}$ & Wards & $\begin{array}{c}\text { Year } \\
\text { Designated }\end{array}$ \\
\hline 1. Blythwood Road & $\begin{array}{l}\text { Ward Number } 15 \text { - Don Valley } \\
\text { West }\end{array}$ & 2005 \\
\hline $\begin{array}{l}\text { 2. Cabbagetown } \\
\text { Metcalfe, } \\
\text { 3. North, } \\
\text { 4. Northwest, } \\
\text { 5. South }\end{array}$ & $\begin{array}{l}\text { Ward Number } 13 \text { - Toronto } \\
\text { Centre }\end{array}$ & $2002-2008$ \\
\hline 6. Draper Street & $\begin{array}{l}\text { Ward Number } 10 \text { - Spadina-Fort } \\
\text { York }\end{array}$ & 1999 \\
\hline 7. East Annex & $\begin{array}{l}\text { Ward Number } 11 \text { - University- } \\
\text { Rosedale }\end{array}$ & 1994 \\
\hline 8. Fort York & $\begin{array}{l}\text { Ward Number } 10 \text { - Spadina-Fort } \\
\text { York. }\end{array}$ & 1985 \\
\hline $\begin{array}{l}\text { 9. Harbord Village } \\
\text { (Phase I) } \\
\text { 10. ( Phase II) }\end{array}$ & $\begin{array}{l}\text { Ward Number } 11 \text { - University- } \\
\text { Rosedale }\end{array}$ & $2005 / 2011$ \\
\hline $\begin{array}{l}\text { 11. Kingswood Road } \\
\text { South }\end{array}$ & $\begin{array}{l}\text { Ward Number } 19 \text { - Beaches-East } \\
\text { York }\end{array}$ & 2010 \\
\hline 12. Lyall Avenue & $\begin{array}{l}\text { Ward Number } 19 \text { - Beaches-East } \\
\text { York }\end{array}$ & 2006 \\
\hline 13. Queen Street West & $\begin{array}{l}\text { Ward Number } 10 \text { - Spadina-Fort } \\
\text { York }\end{array}$ & 2007 \\
\hline 14. Riverdale & $\begin{array}{l}\text { Ward Number } 14 \text { - Toronto- } \\
\text { Danforth }\end{array}$ & 2008 \\
\hline $\begin{array}{l}\text { 15. Rosedale South, } \\
\text { 16. North) }\end{array}$ & $\begin{array}{l}\text { Ward Number } 11 \text { - University- } \\
\text { Rosedale }\end{array}$ & $2002 / 2004$ \\
\hline 17. Union Station & Number 10 - Spadina-Fort York & 2006 \\
\hline 18. Weston Phase 1 & $\begin{array}{l}\text { Ward Number } 5 \text { - York South- } \\
\text { Weston }\end{array}$ & 2006 \\
\hline $\begin{array}{l}\text { 19. West Annex Phase } \\
\text { 1: Madison Avenue }\end{array}$ & $\begin{array}{l}\text { Ward Number } 11 \text { - University- } \\
\text { Rosedale }\end{array}$ & $\begin{array}{l}2015 \text { (LPAT } \\
\text { approved 2019) }\end{array}$ \\
\hline 20. Wychwood Park & $\begin{array}{l}\text { Ward Number } 12 \text { - Toronto-St. } \\
\text { Paul's }\end{array}$ & 1985 \\
\hline 21. Yorkville - Hazelton & $\begin{array}{l}\text { Ward Number } 11 \text { - University- } \\
\text { Rosedale }\end{array}$ & 2002 \\
\hline
\end{tabular}

Note: Adapted from the City of Toronto’s Heritage Preservation Services (HPS) information on HCDs, 2020. 
Figure 3

Heritage Conservation Districts Map

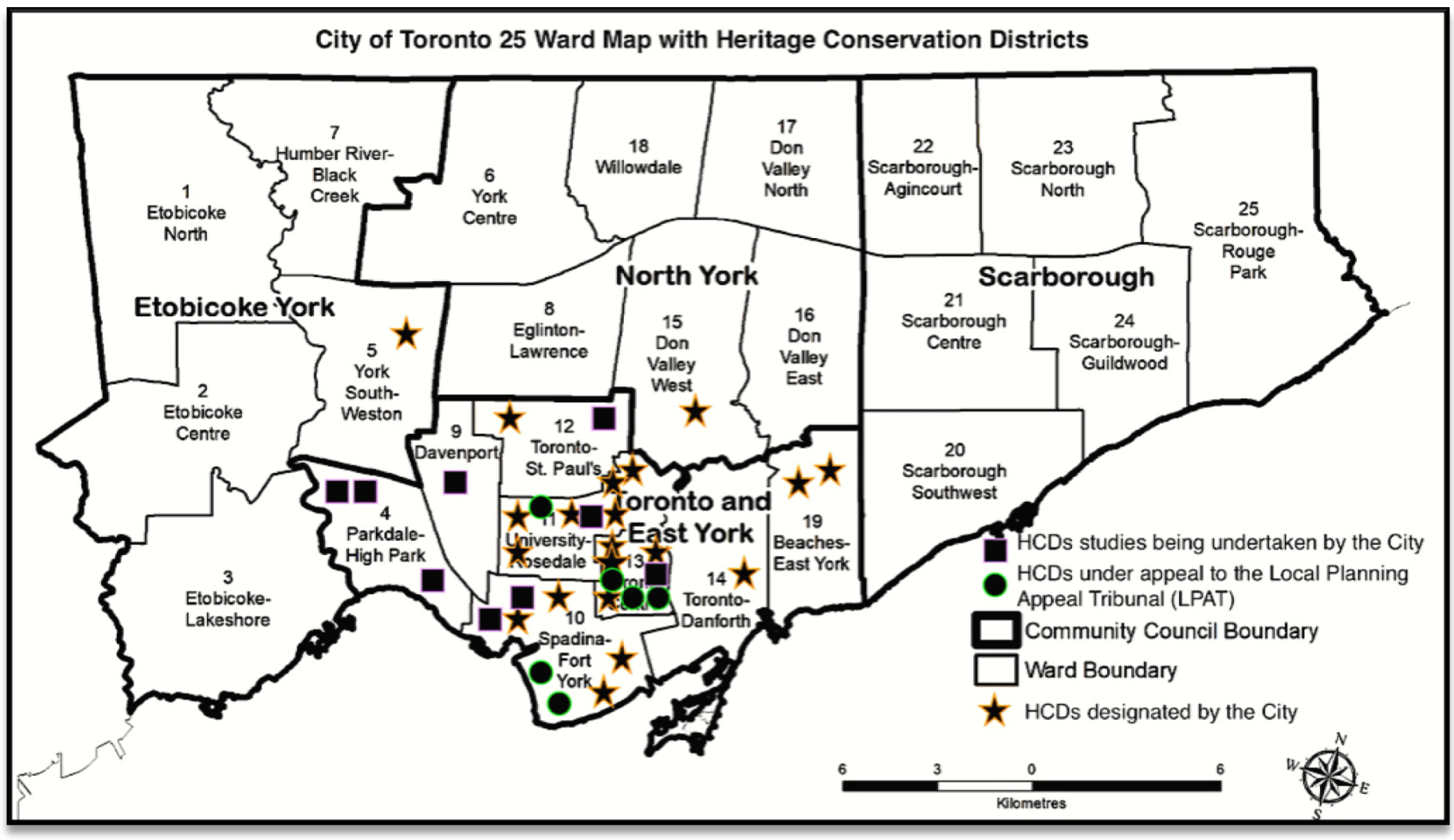

Note: Adapted from the City of Toronto's Heritage Preservation Services (HPS) information on HCDs, 2020.

Table 4

Heritage Conservation Districts Under Appeal at the Local Planning Appeal Tribunal (LPAT)

\begin{tabular}{|l|l|l|l|}
\hline Heritage Conservation Districts & \multicolumn{1}{|c|}{ Ward(s) } & \multicolumn{1}{|c|}{$\begin{array}{c}\text { Year } \\
\text { Designated }\end{array}$} & $\begin{array}{c}\text { LPAT Case } \\
\text { Number }\end{array}$ \\
\hline Garden District & Ward Number 13-Toronto Centre & 2017 & MM170028 \\
\hline $\begin{array}{l}\text { Historic Yonge Street (Part 1, } \\
\text { Part 2, Part 3) }\end{array}$ & $\begin{array}{l}\text { Ward Number 13-Toronto Centre, } \\
\text { Number 11 - University-Rosedale }\end{array}$ & 2016 & MM150018 \\
\hline $\begin{array}{l}\text { King-Spadina (Part 1 ,Part 2, } \\
\text { Part 3, Part 4 ) }\end{array}$ & $\begin{array}{l}\text { Ward Number 10-Spadina-Fort } \\
\text { York }\end{array}$ & 2017 & MM170097 \\
\hline $\begin{array}{l}\text { St. Lawrence Neighbourhood } \\
\text { (Part 1 , Part 2, Part 3, Part 4) }\end{array}$ & $\begin{array}{l}\text { Ward Number 13-Toronto Centre } \\
\text { Ward Number 10-Spadina-Fort } \\
\text { York }\end{array}$ & 2015 & MM160020 \\
\hline
\end{tabular}

Note: Adapted from the City of Toronto's Heritage Preservation Services (HPS) information on HCDs,2020 


\section{Table 5}

Heritage Conservation Districts in Development

\begin{tabular}{|l|l|l|}
\hline \multicolumn{1}{|c|}{ Heritage Conservation District } & \multicolumn{1}{|c|}{ Ward(s) } & $\begin{array}{c}\text { Year(s) } \\
\text { Initiated }\end{array}$ \\
\hline Baby Point & Ward Number 4 - Parkdale-High Park & 2017 \\
\hline Bloor West Village & Ward Number 4 - Parkdale-High Park & 2016 \\
\hline Cabbagetown Southwest & Ward Number 13 - Toronto Centre & 2018 \\
\hline Distillery District & Ward Number 10 - Spadina-Fort York & 2016 \\
\hline Kensington Market & Ward Number 11 - University-Rosedale & 2015 \\
\hline $\begin{array}{l}\text { West Queen West \& Parkdale Main } \\
\text { Street }\end{array}$ & Ward Number 10 - Spadina-Fort York & 2016 \\
\hline Hilton Avenue \& Wells Hill Avenue & Ward Number 12 - Toronto-St. Paul's & 2018 \\
\hline The Junction Phase 1 & Ward Number 4 - Parkdale-High Park & 2014 \\
\hline Weston II & Ward Number 9 - Davenport & 2004 \\
\hline
\end{tabular}

Note: Adapted from the City of Toronto's Heritage Preservation Services (HPS) information on HCDs, 2020.

\subsection{Heritage Property Designation and It's Relationship to HCDs}

In addition to the designation of Heritage Conservation Districts in the City of Toronto,"section 27 of the Ontario Heritage Act gives municipalities the authority to maintain and add to a publicly accessible heritage register"(City of Toronto-Heritage Preservation Services, 2020, para. 2). The City of Toronto has maintained a publicly accessible online register, which includes a list of all designated properties, and conservation districts within the municipality. Further," 'listed' properties, those that are not designated, but are believed to be of 'cultural heritage value or interest'...listed properties on the City's Heritage Register are flagged for review by Heritage Preservation Services Planning staff "(City of Toronto-Heritage Preservation Services, 2020, para. 2).

In addition, after a property is listed, the City can "undertake further research and evaluation of the property and may recommend designation of the property under Part IV of the Ontario Heritage Act”(City of Toronto-Heritage Preservation Services, 2020, sec. How Listing is 
Implemented by Staff). The City has two types of tools to help the public access information on heritage properties, and these include the Heritage Register Map, which is an interactive map that plots heritage properties (designated and listed), and Heritage Conservation Districts [designated, under appeal and understudy](see Figure 4). The Heritage Property Search Tool (see Figure 5) is "the most up-to-date way of confirming whether a property is on the Heritage Register"(City of Toronto-Heritage Preservation Services, 2020, sec. Heritage Register)

To assist residents, The City of Toronto created two "heritage incentive programs to assist owners of eligible heritage properties with the cost of conservation: the Heritage Grant Program and the Heritage Tax Rebate"(City of Toronto, Heritage Preservation Services, 2020b, para. 1). The Toronto Heritage Grant Program has existed “since 1986”(City of Toronto, Heritage Preservation Services, 2020a, para. 1). It provides "matching grant funds for eligible heritage conservation work to owners of properties that are designated under Part IV or Part V of the Ontario Heritage Act"(City of Toronto, Heritage Preservation Services, 2020a, para. 1).

Further, the City of Toronto has offered a Heritage Tax Rebate since 2007. Although in "2015 the program was significantly restructured to focus eligibility on commercial and industrial properties designated under Part IV (individually) or Part V (part of a Heritage Conservation District) of the Ontario Heritage Act'(City of Toronto, Heritage Preservation Services, 2020c, para. 1). When examining the City's current support of heritage in all former municipalities, it is evident that there are gaps. The best example of this is the uneven representation of heritage properties across the City of Toronto. The City's heritage register divides properties of historical and cultural significance by the pre-existing four-community Council area's (Etobicoke York, North York, Toronto and East York and Scarborough). 
As of 2018, the City of Toronto had 11,695 heritage properties, but when you look at the individual sections of the City, the data is intriguing. In North York, there are only " 475 heritage properties"(Heritage Toronto, 2019, p. 19) and, the number reduces in Etobicoke, where there are only " 403 " heritage properties. The lowest rate of heritage properties is in Scarborough, with less than half of Etobicoke and North York properties standing at “163”(Heritage Toronto, 2019, p. 19). What is worse is that if you combine all the areas that became part of the City of Toronto post-amalgamation, they don't equal the number of heritage properties that the downtown core of Toronto and East York have, which are “10,654”(Heritage Toronto, 2019, p. 19).

In 2020, this trend continued as the total number of City of Toronto heritage properties increased to 14,559; however, there is still an uneven distribution of properties across the City. In the illustration created below (see Figure 6), Toronto/East York heritage properties have increased at the highest rate coming in at 12,885, which is an increase of 2201 properties. North York has 769 heritage properties, Etobicoke has 704 heritage properties, 'and Scarborough is still far below all the other inner suburban areas with 201 heritage properties. Data for Figure 6 was created from the Heritage Property Search Tool, and MacBook Pages generated icons.

Further, Figure 7, which is a screengrab of the City's Heritage register map, highlights the density of heritage properties in Toronto/East York compared to Scarborough, where the increase in the number of heritage properties from April 2018 to June 2020 was only 38, which is a notable finding. The discrepancies in heritage property designation, as well as Heritage Conservation Districts across the City of Toronto, are linked to Toronto's 1998 amalgamation. Heritage Toronto confirmed this discrepancy in its 2019 State of Heritage report. They suggest that: 
the overwhelming proportion of designated properties in central Toronto in comparison to regions such as North York and Scarborough on the City's Heritage Register (does not demonstrate) a lack of heritage properties in these areas but a failure to recognize them. (Heritage Toronto, 2019, p. 19)

Heritage Toronto also noted that "the addition of satellite offices for the City's heritage services, situated in Etobicoke or Scarborough, may be better able to respond and process requests for local communities"(Heritage Toronto, 2019, p. 19). Their sentiments about the difficulties in heritage preservation and the effects of amalgamation are not new. In 2001, Heritage Toronto noted that in the post-amalgamation period, "roles of the Toronto Preservation Board and the Community Preservation Panels were still unclear"(Heritage Toronto et al., 2015, p. 8). Further, when these roles were clarified, no progress was noted in a "decade or more"(Heritage Toronto et al., 2015, p. 8). After Heritage Toronto expressed their concerns, it was noted in the State of Heritage report in 2015 their collaboration with representatives of former municipalities was largely still a work in progress. As one can determine, the disproportionate designation of HCDs and heritage properties are connected. Further, if the number of heritage properties can be increased, then there is hope for HCD designation in parts of the city that are lacking.

The next section will explore the lack of HCDs in Scarborough by examining two proposed HCDs for the area, known as Agincourt Heritage Conservation District and Midland Park Heritage Conservation District. These HCD case studies have unique back-stories but both illustrate the highs and lows that occur in the heritage designation process. 


\section{Figure 4}

Screengrab of Heritage Register Interactive Map

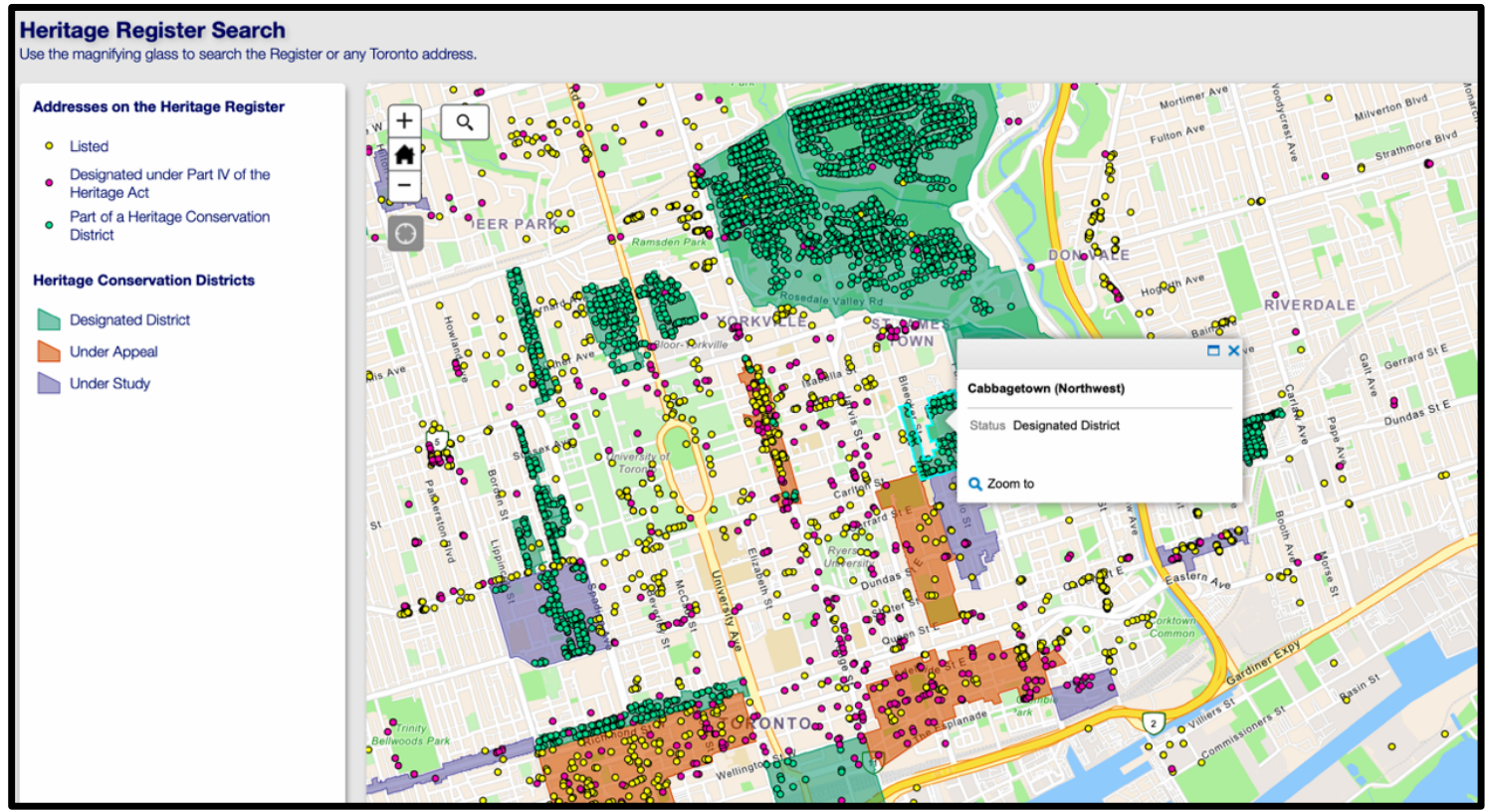

Note: Adapted from a screengrab sourced from the City of Toronto's Heritage Register Interactive Mapping System, 2020.

\section{Figure 5}

Screengrab of the Heritage Property Search Tool

\section{MOITTRONII

\section{City of Toronto's Heritage Property Search}

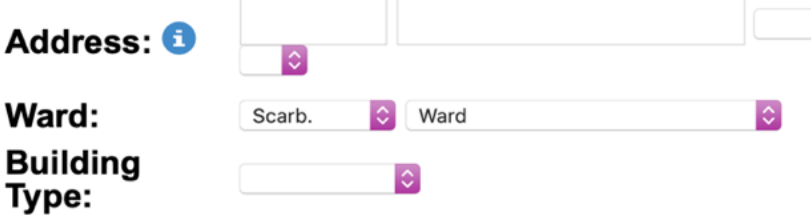

Architect:

\section{Construction}

Yr:

\section{District:}

\section{RESET}

\section{SUBMIT}

Note: Adapted from a screengrab sourced from the City of Toronto's Heritage Register,2020. 
Figure 6

Heritage Properties in City of Toronto

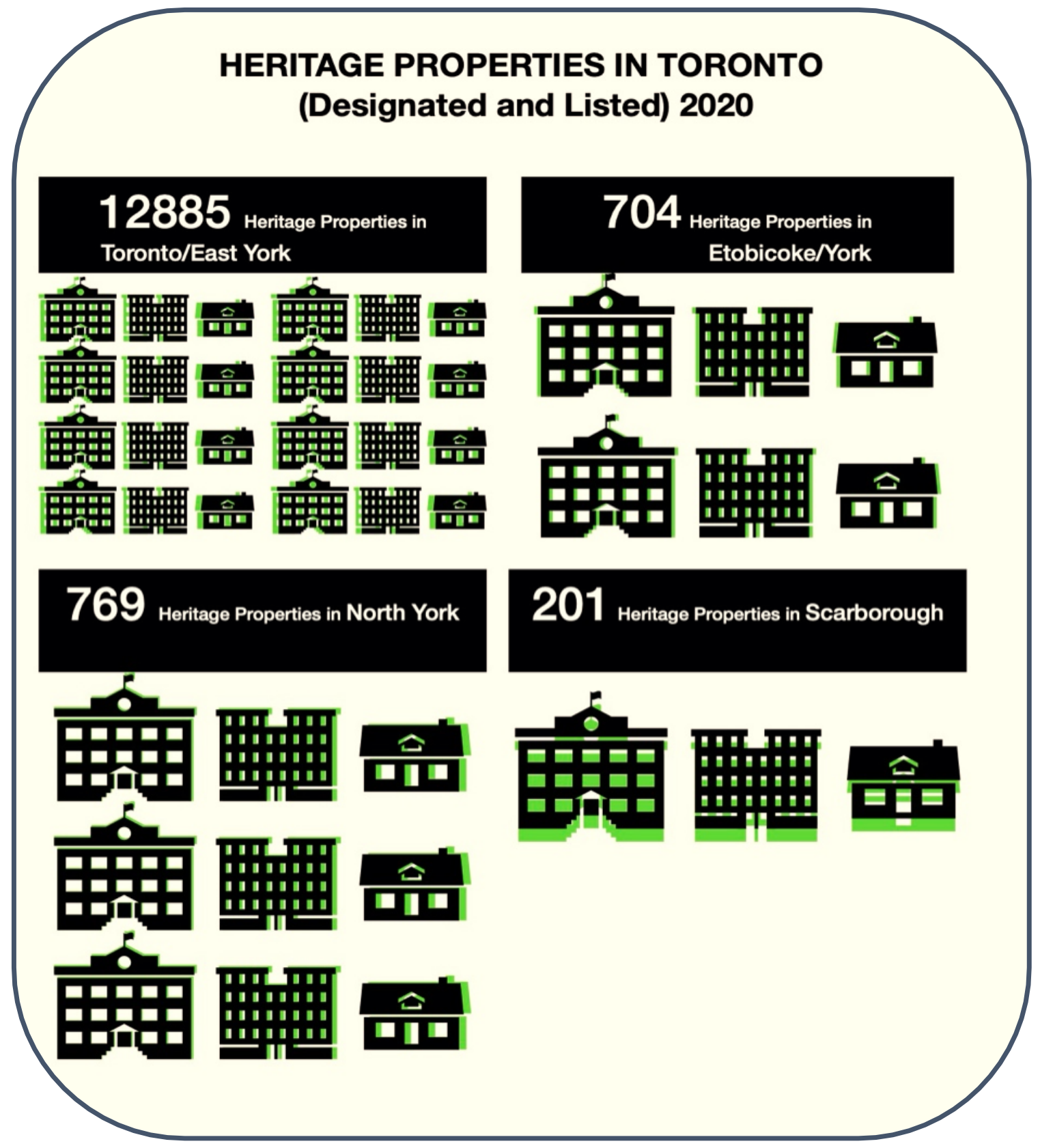

Note: Adapted from the City of Toronto's Heritage Register search tool, 2020. 


\section{Figure 7}

Screengrab of The City of Toronto's Heritage Properties Interactive Heritage Mapping System

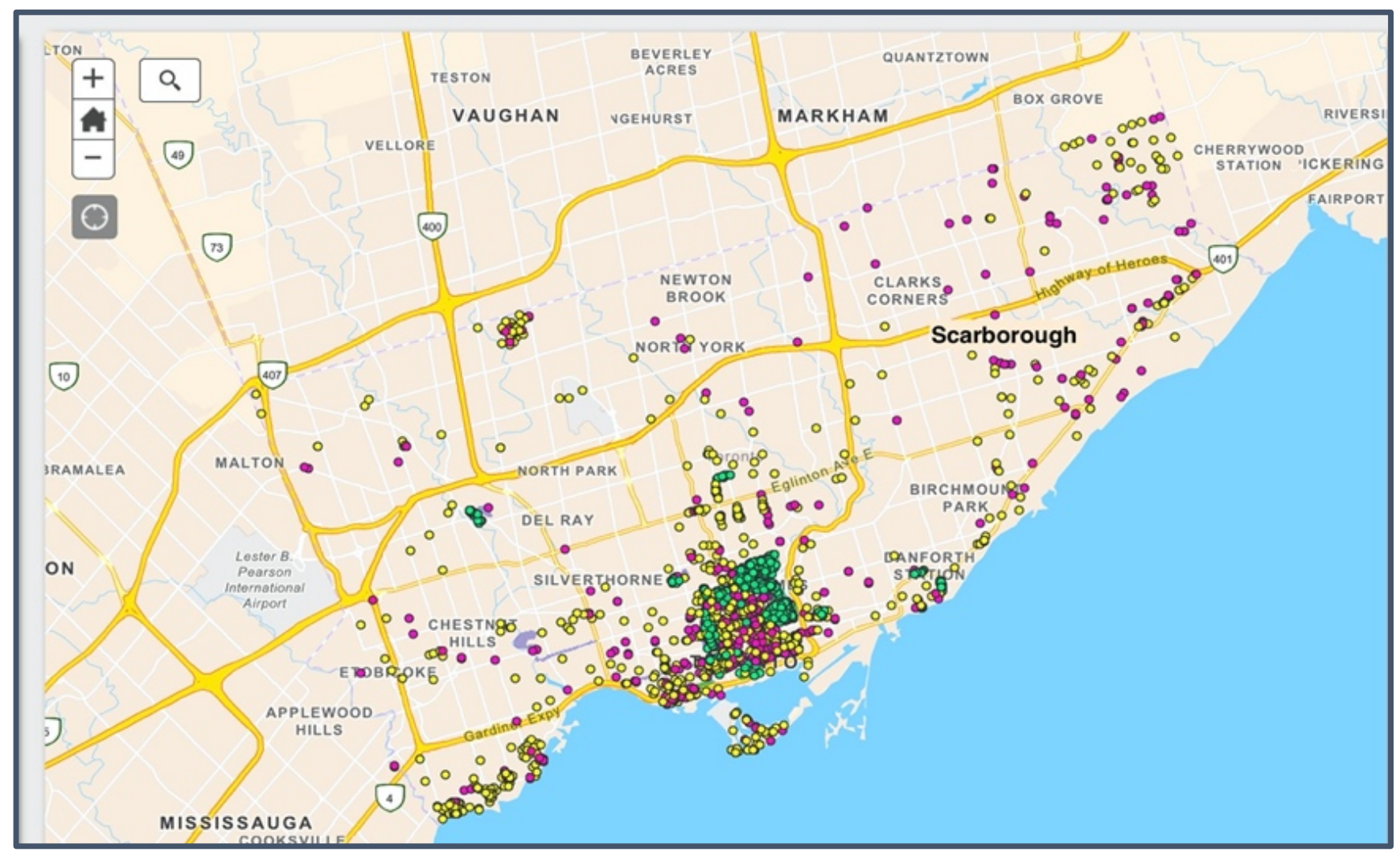

Note: Adapted from a screengrab from the City of Toronto's Heritage Register Interactive Heritage Mapping System, 2020.

\subsection{HCD Case Study 1\#: Agincourt Heritage Conservation District}

Scarborough Agincourt "began as a small village centred around the Knox Presbyterian Church, constructed in 1846 and rebuilt in 1872 on the northwest corner of Sheppard and Midland Avenue"(Gendron \& Heritage Preservation Services, 2005, p. 1). Further, "the most significant wave of development in Agincourt took place between 1945 and 1965 when most of the present-day neighbourhoods were developed"(Gendron \& Heritage Preservation Services, 2005 , p. 2). At present, there are fourteen heritage properties, comprised of seven designated and seven listed. All but one of the designations were made after amalgamation. Still, some of the most widely cited heritage properties are "Knox United Church and its manse, originally built in 1872 and expanded in later years, [which] is also designated ...”(Scarborough Community 
Council \& Director, Community Planning, 2013, p. 4). In addition, Agincourt Junior Public School is also a heritage property, "originally constructed in 1914 to serve the Village of Agincourt, and later expanded in 1948"(Scarborough Community Council \& Director, Community Planning, 2013, p. 4).

As I've previously noted, Heritage Toronto flagged the delay in the designation of Scarborough Agincourt or any designation in the area for that matter in 2019; they noted that “even with a population of over 600,000 , comprising $20 \%$ of Toronto's area, Scarborough has yet to have a Heritage Conservation District"(Heritage Toronto, 2019b, p. 20). They provided no specific rationale for the delay in Scarborough HCD and noted that the process to approve Agincourt as a "potential designation under Part V of the Ontario Heritage Act and to seek authority for the City to receive donations"(Heritage Toronto, 2019b, p. 20) took place in September 2005.

Initially nominated under (Ward 41 - Scarborough Rouge River), most of Agincourt's HCD is currently part of Ward 22 (per the New 25 Ward Map), which is Scarborough Agincourt, but part of its boundary (Rural Ave) straddles between Scarborough Agincourt and Ward 23 (Scarborough North). Overall the potential designation area is "bounded by Sheppard Avenue East to the south, the Canadian National Railway tracks to the west, Lockie Avenue to the north, and Midland Avenue to the east"(Gendron \& Heritage Preservation Services, 2005, p. 2). The Scarborough Community Council had several recommendations, which they wanted Toronto City Council to adopt. Between September 28th and 30th, 2005 Report 7, was considered by City Council, and then adopted "without amendment"(Gendron \& Heritage Preservation Services, 2005, p. 1). The recommendations are as follows:

(1) City Council identify the area shown in Attachment 1 of this report as the Agincourt 


\section{Heritage Conservation District Study Area; (see Figure 8)}

(2) City Council authorize the acceptance of donations to be used to conduct the Agincourt Heritage Conservation District Study until August 30, 2006, and that all donations received be held in a separate account designated for that purpose;

(3) City Council authorize the reimbursement of the community group selected to conduct the study from donations received for that purpose, upon completion of the professional work to the satisfaction of the Chief Planner and Executive Director of City Planning;

(4) The Treasurer be authorized to issue an Income Tax receipt to the donor for funds donated in the amount of $\$ 10$ or more; and

(5) The appropriate City Officials be authorized and directed to take the necessary action to give effect thereto. (Gendron \& Heritage Preservation Services, 2005, p. 1)

Before the adoption of Agincourt as a potential HCD by City council, the Scarborough Community Preservation Panel noted that "for some time (we have) been interested in how Heritage Conservation District designation could assist in the preservation and enhancement of the heritage streetscapes of this historic Scarborough village"(Gendron \& Heritage Preservation Services, 2005, p. 2). Scarborough Community Preservation Panel Council minutes state that a "neighborhood meeting was held on May 25, 2005, which staff attended and the Scarborough Community Preservation Panel"(Gendron \& Heritage Preservation Services, 2005, p. 2). Further, it noted that the Panel made a presentation about the "benefits and implications of a Heritage Conservation District for Agincourt Village as Agincourt is a good example, both architecturally and historically, of an original rural hamlet engulfed by post-World War II suburban development"(Gendron \& Heritage Preservation Services, 2005, p. 2). 


\section{Figure 8}

City of Toronto's Attachment 9A HCD Prioritization Map-Agincourt HCD

Attachment 9B - Map 9-Study Boundary: Agincourt

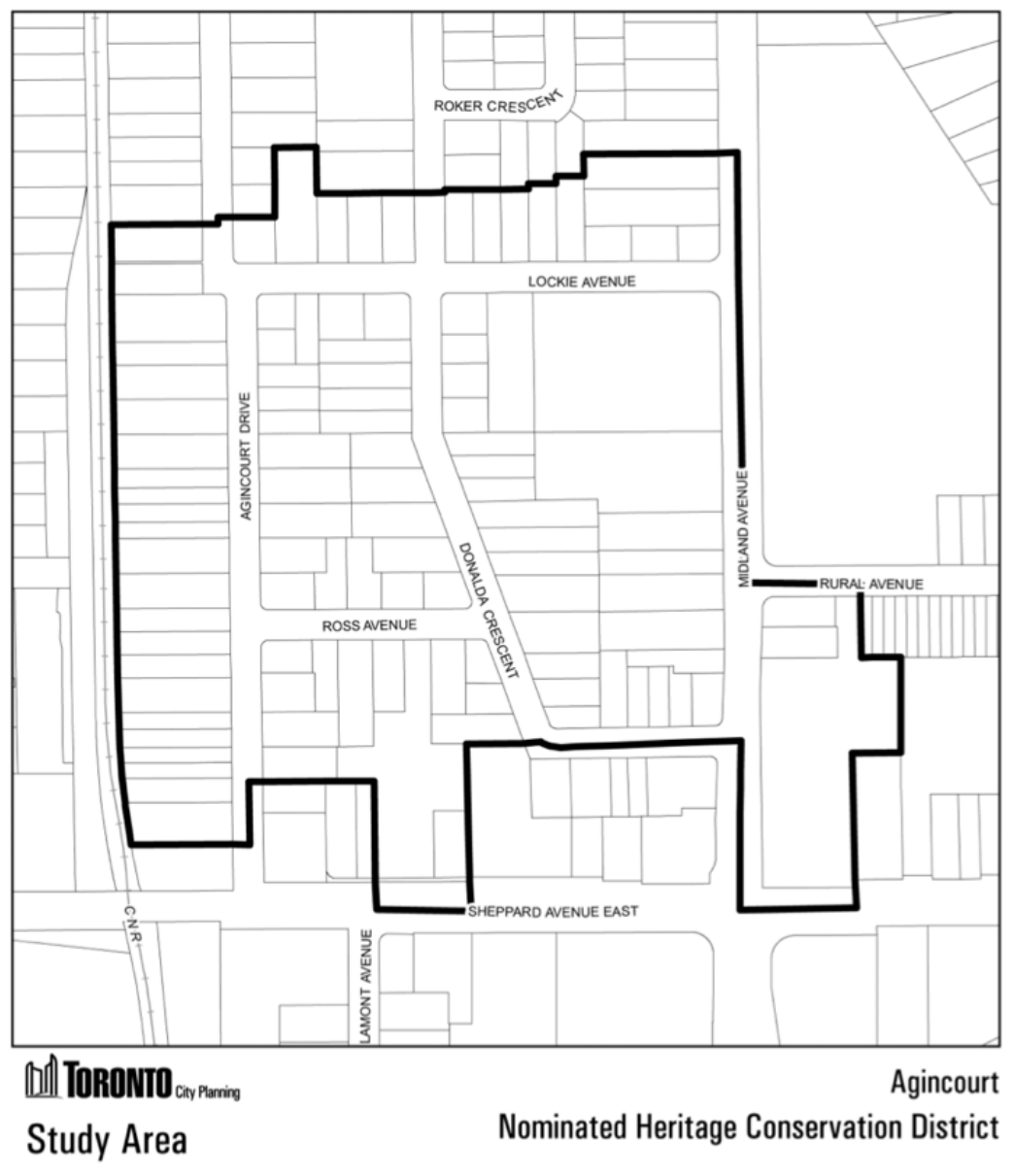

Not 105 cale
$1 / 23212015$

Note: Adapted from the City of Toronto's Heritage Attachment 9A HCD Prioritization Report,2015.

Representatives from the City's planning division explained to the Panel as well as

Agincourt residents "that they would be responsible for the work and expense of studying the area and preparing a District Plan for City Council's consideration with the assistance of Planning staff "Gendron \& Heritage Preservation Services, 2005, p. 2). Overall, it said that the 
meeting was a success with "unanimous agreement from the Panel, residents, and the city councillor"(Gendron \& Heritage Preservation Services, 2005, p. 2). After the success of the community consultation and presentation, "local volunteers" (Gendron \& Heritage Preservation Services, 2005, p. 3) were said to be recruited to work alongside "a professional heritage consultant engaged by and paid by the Scarborough Community Preservation Panel and local residents, from donations received [to conduct the study]"'(Gendron \& Heritage Preservation Services, 2005, p. 2). During the process, it was stated that more "public participation and consultation with the area's property owners and residents will occur" (Gendron \& Heritage Preservation Services, 2005, p. 3).

To complete the study of the area, they (professional heritage consultant, Panel, residents) needed to "formulate a statement of the objectives of the Heritage Conservation District, an analysis of the suitability of the area for designation, boundary rationale and review of existing City policies”(Gendron \& Heritage Preservation Services, 2005, p. 3). These components were needed to "determine the history of the buildings in Agincourt, their architectural and historical significance and the growth and evolution of the neighborhood" (Gendron \& Heritage Preservation Services, 2005, p. 3). If the study by the parties involved were seen as successful, then Toronto City Council would designate and "the study would form the district plan required by the $A c t$ '(Gendron \& Heritage Preservation Services, 2005, p. 3). On July 19th, 2008, almost three years after the meeting of the Panel and the community was first held, the Toronto preservation board noted, "that on June 3, 2008, a letter from Bob Saunders, Scarborough Community Preservation Panel was received"(City of Toronto, Heritage Preservation Services, 2008, p. 6). The letter stated, "at this time no study [should] be undertaken 
for the establishment of a heritage conservation district in the old village of Agincourt"(City of Toronto, Heritage Preservation Services, 2008, p. 6).

The motion to receive the letter "was moved by Edith Geduld and the Toronto preservation board voted to carry [the request]"(City of Toronto, Heritage Preservation Services, 2008, p. 6). The letter further noted that during an Agincourt Heritage Conservation District steering committee meeting in May 2008, there was “consensus"(B. Saunders \& Scarborough Community Preservation Panel, personal communication, June 3, 2008), as the committee decided "it did not wish to move forward with a study to establish a district [in Agincourt]"(B. Saunders \& Scarborough Community Preservation Panel, personal communication, June 3, 2008). The chair recommended that the Panel put their energy towards "undertaking a review of individual properties in the area"(B. Saunders \& Scarborough Community Preservation Panel, personal communication, June 3, 2008). Further, the letter noted that Chin Lee, the Councillor of the Ward at the time, was very supportive of the actions required for designation but was "relieved [as he had] received negative comments from a number of residence"(B. Saunders \& Scarborough Community Preservation Panel, personal communication, June 3, 2008).

The negative comments are sourced from a divide in the local community because "many houses sit on large lots which are valuable for redevelopment"(Scarborough Community Preservation Board \& Saunders, 2015, p. 3). Further, one of the residents was quoted as saying that "our home is going to provide a nest egg for us when we retire. I do not want it lost" (Scarborough Community Preservation Board \& Saunders, 2015, p. 3). Mr. Saunders further stated that the experience was a lesson learned because the "initiative has to come from the community itself and their needs to be broad local support"'B. Saunders \& Scarborough Community Preservation Panel, personal communication, June 3, 2008, p. 3). After the decision 
was communicated to the council, Agincourt HCDs was still carried forward in various City Council heritage decision reports as a potential area of study.

For example, in August 2008, Agincourt was named, in a supplementary report on the revision of the Official Plan Amendment, to Authorize Section 37 Funding of Heritage Conservation District Studies as a potential area of study. This trend continued in 2011 when Toronto City Council adopted the Heritage Conservation Districts in Toronto: Procedures, Policies and Terms of Reference document. Council noted that the area already approved for study would be "grand parented into the new system by allowing them to make use of the research and analysis that has been completed to date"(Chief Planner and Executive Director, 2011, p. 7). This grandparenting of the HCD was approved "so long as it satisfies the minimum requirements of the OHA, and the evaluation criteria in section 7 of HCDs in Toronto" (Scarborough Community Preservation Board \& Saunders, 2015, p. 3).

In 2012, City Council noted that, in addition to Agincourt's HCD, "nine potential HCDs were authorized for study before HCDs in Toronto was adopted and an additional three potential HCD study areas [were] nominated by either Council or by members of the community"(Chief Planner and Executive Director, 2012, p. 3). Further, "council directed staff to develop a prioritization system to determine which potential heritage conservation districts should be undertaken first"(Chief Planner and Executive Director, 2012, p. 4). As a result, "eight potential HCD study areas were prioritized based on the criteria developed by staff to be adopted by Council” (Chief Planner and Executive Director, 2012, p. 5).

The City of Toronto's prioritization criteria uses “high, medium, or low priority”(Chief Planner and Executive Director, 2012, p. 5) to indicate the level of priority for a potential HCD study area. In addition, prioritization of HCDs relies on four key categories and they include 
"Development Activity, Existing Levels of Protection, The Fragility of Area,[and] Planning

Priorities" (Chief Planner and Executive Director, 2012, p. 5-7). In February 2015, an additional fifth criterion was added to the prioritization system called "Archaeology"(Chief Planner and Executive Director, City Planning, 2015, p. 6); see Table 6.

With the addition of the Archaeology as a prioritization category, the city made slight changes to the prioritization criteria definitions. They noted that the changes occurred to "allow for relative comparison of nominated HCD study areas to each other"(Chief Planner and Executive Director, City Planning, 2015, p. 4). They further noted that the changes were considered after looking at "data from 2009-2013 ... (as it was the ) most recent full-year of data available"(Chief Planner and Executive Director, City Planning, 2015, p. 4).

\section{Table 6}

Heritage Conservation District Studies Prioritization Criteria

\begin{tabular}{|l|l|}
\hline $\begin{array}{l}\text { Prioritization } \\
\text { Category }\end{array}$ & \multicolumn{1}{c|}{ Description } \\
\hline $\begin{array}{l}\text { Development } \\
\text { Activity }\end{array}$ & $\begin{array}{l}\text { This category assesses whether a potential HCD study area is currently } \\
\text { undergoing an increased level of development activity and is therefore at a higher } \\
\text { immediate risk of the loss of cultural heritage value. Priority is given to areas } \\
\text { with higher development or permit activity. Staff analyzed average numbers of } \\
\text { planning applications, minor variances, building and demolition permit } \\
\text { applications for each nominated district. Determination of "few", "moderate" and } \\
\text { "significant" numbers of applications was based on a relative comparison } \\
\text { between potential HCDs. }\end{array}$ \\
\hline $\begin{array}{l}\text { Existing level } \\
\text { of Protection }\end{array}$ & $\begin{array}{l}\text { This category assesses the degree to which existing heritage protection is already } \\
\text { in place, either through properties being listed on the City's Heritage Register or } \\
\text { designated under Part IV of the Ontario Heritage Act. Areas with less existing } \\
\text { heritage protection have been prioritized over areas with more existing heritage } \\
\text { protection. Determination of "few", "moderate" and "significant" numbers of } \\
\text { properties with heritage protection was based on a relative comparison between } \\
\text { potential HCDs. }\end{array}$ \\
\hline
\end{tabular}




\begin{tabular}{|l|l|}
\hline $\begin{array}{l}\text { Fragility of } \\
\text { Area }\end{array}$ & $\begin{array}{l}\text { This category assesses the degree to which a potential HCD study area has been } \\
\text { subject to increased levels of neglect, lack of maintenance or willful damage. } \\
\text { Fragile areas with widespread neglect, willful damage to heritage buildings and } \\
\text { frequent fires are prioritized over less fragile areas. Staff relied on Municipal } \\
\text { Licensing and Standards data from 2009-2013 to determine priority, which was } \\
\text { based on a relative comparison between potential HCDs. }\end{array}$ \\
\hline $\begin{array}{l}\text { Planning } \\
\text { Priorities }\end{array}$ & $\begin{array}{l}\text { This category assesses whether a potential HCD study area is currently part of } \\
\text { ongoing planning studies or Official Plan amendments. Prioritization has been } \\
\text { given to potential HCD study areas that are currently a part of a planning study or } \\
\text { Official Plan Amendment so that heritage review and planning can be fully } \\
\text { regarded in, and complement, other planning documents underway. }\end{array}$ \\
\hline Archaeology & $\begin{array}{l}\text { This category is recommended for inclusion in order to recognize the value of } \\
\text { archaeology in nominated districts and to address the current risk to known or } \\
\text { potential archaeological sites. Furthermore, HCD designation would allow for } \\
\text { better management of archaeological resources by giving the City authority to } \\
\text { require archaeological assessments through the heritage permitting system. } \\
\text { Priority is given to areas with known Archaeologically Sensitive Areas (ASAs) }\end{array}$ \\
\hline
\end{tabular}

Note: Adapted from the City of Toronto's Heritage Conservation District Studies Prioritization Criteria, 2015.

The indication of priority for potential HCD study areas is not a reflection of potential or perceived cultural heritage value or a ranking of significance. The City Chief planner notes that “considerations, such as council priority, may also be taken into account, (changing) the priority level that would otherwise be assigned"(Chief Planner and Executive Director, 2012, p. 8). It was noted that "staff resources allocated to the HCD study process will allow for a maximum of three Heritage Conservation District studies to be in progress at any given time" (Chief Planner and Executive Director, 2012, p. 9). Further, City Council discussed adding a category that represents “cultural heritage value”(Chief Planner and Executive Director, City Planning, 2015, p. 7). Still, to date, this cultural heritage value is not an official category.

Agincourt was assessed and received a "medium priority"(Chief Planner and Executive Director, City Planning, 2015, p. 7), along with seven other districts. The City noted that medium priority districts "will be reviewed in the next prioritization analysis"(Chief Planner and Executive Director, City Planning Division, 2015, p. 7). Agincourt only received one high 
assessment in the category of existing level of protection (see Figure 9). The City noted in a

prioritization worksheet for Agincourt HCD (see Figure 10) that "approximately 96\% of

properties have no form of heritage protection in the nominated district"(Keesmaat \& City of

Toronto-Chief Planner and Executive Director, 2015, p. 25).

Figure 9

Chart of Prioritization Outcomes in the City of Toronto's Heritage Conservation District (20152016)

\begin{tabular}{|l|c|c|c|c|c|c|}
\hline \multicolumn{1}{|c|}{ District. } & $\begin{array}{c}\text { Development } \\
\text { Activity }\end{array}$ & $\begin{array}{c}\text { Existing Level } \\
\text { of Protection }\end{array}$ & Fragility & $\begin{array}{c}\text { Planning } \\
\text { Priorities }\end{array}$ & Archaeology & PRIORITY \\
\hline Baby Point & HIGH & HIGH & LOW & LOW & HIGH & HIGH \\
\hline Bloor St W & HIGH & HIGH & MEDIUM & MEDIUM & MEDIUM & HIGH \\
\hline Cabbagetown SW & MEDIUM & MEDIUM & HIGH & HIGH & LOW & HIGH \\
\hline Casa Loma & HIGH & HIGH & LOW & LOW & MEDIUM & HIGH \\
\hline Distillery District & HIGH & LOW & MEDIUM & HIGH & MEDIUM & HIGH \\
\hline Kensington Market & LOW & HIGH & HIGH & HIGH & LOW & HIGH \\
\hline Kingsway & HIGH & HIGH & LOW & LOW & MEDIUM & HIGH \\
\hline West Queen West & HIGH & HIGH & HIGH & HIGH & LOW & HIGH \\
\hline Agincourt & LOW & HIGH & LOW & LOW & MEDIUM & MEDIUM \\
\hline Harbord Village 3 & LOW & HIGH & LOW & HIGH & LOW & MEDIUM \\
\hline Leaside & MEDIUM & HIGH & LOW & MEDIUM & LOW & MEDIUM \\
\hline Liberty Village & LOW & MEDIUM & LOW & HIGH & LOW & MEDIUM \\
\hline Summerhill & MEDIUM & HIGH & LOW & LOW & LOW & MEDIUM \\
\hline The Junction & LOW & HIGH & LOW & MEDIUM & LOW & MEDIUM \\
\hline West Annex & MEDIUM & MEDIUM & MEDIUM & LOW & MEDIUM & MEDIUM \\
\hline Weston Phase II & LOW & HIGH & LOW & LOW & MEDIUM & MEDIUM \\
\hline
\end{tabular}

Note: Adapted from the City of Toronto's HCD Prioritization System Presentation to the Planning and Growth Management Committee. 


\section{Figure 10}

HCD Prioritization Criteria for Agincourt HCD 2015

\section{Attachment 9A \\ HCD Prioritization Criteria \\ Potential HCD Name: Agincourt}

Note: Determination of "significant", "high", "moderate", "low", "little" or "few" was relative and based on a comparison between all 16 nominated districts in this prioritization analysis.

\begin{tabular}{|c|c|c|}
\hline Criteria by Category & Level & $\begin{array}{c}\text { Check } \\
\text { ONE }\end{array}$ \\
\hline Development Activity & $\mathrm{H}$ & \\
\hline $\begin{array}{l}\text { 1. Potential district has a significant number of planning, Committee of } \\
\text { Adjustment, building or demolition applications, 2009-2013. }\end{array}$ & $\mathrm{M}$ & \\
\hline $\begin{array}{l}\text { 2. Potential district has a moderate number of planning, Committee of } \\
\text { Adjustment, building or demolition applications, 2009-2013. }\end{array}$ & $\mathrm{L}$ & $\mathrm{X}$ \\
\hline $\begin{array}{l}\text { 3. Potential district has few planning, Committee of Adjustment, } \\
\text { building or demolition applications, 2009 -2013. }\end{array}$ & & \\
\hline
\end{tabular}

Notes: The nominated district had a low number of planning, Committee of Adjustment, building or demolition applications, $2009-2013$, for its size.

\begin{tabular}{|c|c|c|}
\hline Existing level of Protection & & \\
\hline $\begin{array}{l}\text { 1. Potential district has a significant number of properties without some } \\
\text { level of heritage protection. }\end{array}$ & H & X \\
\hline $\begin{array}{l}\text { 2. Potential district has a moderate number of properties without some } \\
\text { level of heritage protection. }\end{array}$ & $\mathrm{M}$ & \\
\hline $\begin{array}{l}\text { 3. Potential district has a low number of properties without some level } \\
\text { of heritage protection. }\end{array}$ & $\mathrm{L}$ & \\
\hline
\end{tabular}

Notes: Approximately $96 \%$ of properties have no form of heritage protection in the nominated district.

\begin{tabular}{|c|c|c|}
\hline Fragility of the Area & H & \\
\hline $\begin{array}{l}\text { 1. Neglect or wilful damage are documented in the area or additional } \\
\text { losses in the area may negatively affect the potential HCD designation }\end{array}$ & $\mathrm{M}$ & \\
\hline 2. General neglect of properties in the area is evident & $\mathrm{L}$ & $\mathbf{X}$ \\
\hline 3. Some maintenance issues but does not appear to be widespread &
\end{tabular}

Notes: Compared to other nominated districts, properties in the nominated district are not likely to be subject to property standards violations for which charges or orders are issued.

Planning Priorities

1. The area will be, or is part of a planning study or Official Plan Amendment, or an HCD study or plan is likely to support related Official Plan objectives

2. The area Is identified as a potential HCD in the Official Plan and/or has not been the subject of a recent planning study

3. A planning study has recently been completed for the area, or is not anticipated in the coming year.

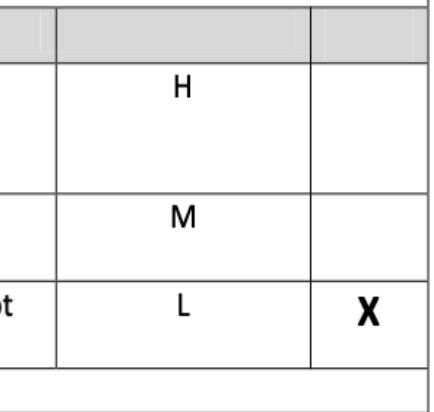




\begin{tabular}{|c|c|c|}
\hline Archaeology & H & \\
\hline $\begin{array}{l}\text { 1. } \\
\text { The nominated district contains an Archaeologically Sensitive Area } \\
\text { (ASA). }\end{array}$ & $\mathrm{M}$ & $\mathrm{X}$ \\
\hline $\begin{array}{l}\text { 2. } \\
\text { The nominated district contains no ASA, but contains a moderate to } \\
\text { high percentage of land area identified as having archaeological } \\
\text { potential. }\end{array}$ & $\mathrm{L}$ & \\
\hline $\begin{array}{l}\text { 3. } \\
\text { percentage of land area identified as having archaeological potential. }\end{array}$ & \\
\hline $\begin{array}{l}\text { Notes: Agincourt has no ASA, but 58\% of its land area has archaeological potential, which is higher than } \\
\text { the median value of all districts (27\%) }\end{array}$ & \\
\hline Other Considerations \\
\hline \multicolumn{2}{|l|}{ Priority: Medium } \\
\hline
\end{tabular}

Note: Adapted from a screengrab of a table from the City of Toronto's Attachment 9A HCD Prioritization Report.

Further, in the archaeology category, it was noted that "Agincourt had no archaeologically Sensitive Areas (ASA), but $58 \%$ of its land area has archaeological potential, which is higher than the median value of all districts [which is] (27\%)"(Keesmaat \& City of Toronto-Chief Planner and Executive Director, 2015, p. 26). In March 2017, a report entitled update on heritage studies noted that Heritage Preservation Services (HPS) staff undertook 11 HCD studies and "while City Council had authorized the study of 11 HCDs under Section 40. (1) of the OHA, they were not yet prioritized in the City's Planning Division Strategic Work Program"(Chief Planner and Executive Director, City Planning Division, 2017, p. 5). They further noted that "the prioritization of future HCD studies was not anticipated before 2018 Q1" (Chief Planner and Executive Director, City Planning Division, 2017, p. 5).

Although Agincourt's HCD was part of the 11 HCDs, the areas' prioritization was pushed aside for another year. In November 2017, a change of events occurred, as City Planning decided to prioritize heritage. They named Agincourt, along with thirteen other districts, as 
“good candidates for a Cultural Heritage Resource Assessment (CHRA)"(Acting Chief Planner and Executive Director, City of Toronto Planning Division, 2017, p. 8). The CHRA process "reviews and describes the historic context and periods of development within the study area, outlines the results of community consultation, and identifies and evaluates potential cultural heritage resources"(Acting Chief Planner and Executive Director, City of Toronto Planning Division, 2017, p.8). Also, the City noted that the initiation of these thirteen outstanding HCDs and the accompanying CHRAs "will be based upon the date when the area was nominated or authorized as indicated"(Acting Chief Planner and Executive Director, City of Toronto Planning Division, 2017, p.8). Further, "together with the consideration of broad City Planning objectives and Divisional priorities, district-based initiatives"(Acting Chief Planner and Executive Director, City of Toronto Planning Division, 2017, p.8) will take place; see Table 7.

\section{Table 7}

Table of Outstanding Heritage Conservation District Studies

\begin{tabular}{|l|l|l|}
\hline HCD Study Area & Year of Authorization & Recommendation \\
\hline Weston Area Phase 2 & 2004 & HCD Study \\
\hline Agincourt & 2005 & CHRA \\
\hline Liberty Village & 2005 & CHRA \\
\hline Summerhill & 2007 & CHRA \\
\hline St. Lawrence Phase 2 & 2015 & HCD Study \\
\hline Belmont-Hillsboro & 2016 & HCD Study \\
\hline Lawrence Park West & 2016 & HCD Study \\
\hline Sunshine Valley & 2017 & HCD Study \\
\hline The Junction Phase 1 & Pending authorization & HCD Study \\
\hline Beaconsfield & Pending authorization & HCD Study \\
\hline Harbord Village Phase 3 & Pending authorization & HCD Study \\
\hline Leaside & Pending authorization & CHRA \\
\hline West Annex Phase 2 & Pending authorization & HCD Study \\
\hline
\end{tabular}

Note: Adapted from the Prioritization of Outstanding Heritage Conservation District Studies and Interim Protective Measures Report, City of Toronto, 2015. 
In December 2017, the Scarborough Community Heritage Preservation Panel discussed the outstanding HCD designation in Agincourt and the City Council's decision to perform a Cultural Heritage Resource Assessment Study (CHRA). The Panel did not express opposition, but they did recall that it was over ten years since they proposed an HCD designation in Agincourt and felt that there had "been no positive action"(Scarborough Community Heritage Preservation Panel, 2017b, p. 8). In the designation of HCDs in Scarborough, they also noted that they had raised “\$17,000”(Scarborough Community Heritage Preservation Panel, 2017b, p. 8) in funds for an HCD study. As a result of "the Phillips property's redevelopment and the subsequent demolition of the historic Johnson House at 2756 Brimley Avenue" (Scarborough Community Heritage Preservation Panel, 2017b, p. 8).

On June 12, 2018, a report from the City Planning Division - Study Work Program, noted that Agincourt had completed Phase one of secondary plans and was projected to enter "Phase 2 of a Planning Framework Review”(Chief Planner and Executive Director, City Planning, 2018, p. 9). This was due to the completion of preliminary work on Agincourt's local mall, which promised to increase the prioritization criteria for development in the area.

The 2017 CHRA directive was placed on hold in both 2018 and 2019. In 2020, the City Planning Study Work Program report noted:

studies may be on hold as a result of more pressing resource assignments, potential duplications with broader pieces of work or lack of alignment with the criteria and strategic priorities mentioned earlier in this report. Items on hold can be activated over time as capacity becomes available.(Chief Planner and Executive Director, City Planning, 2020, p. 26) 
Agincourt's HCD is not currently mentioned in any City documents, and as heritage Toronto notes, "the residents of the Agincourt neighbourhood do not yet have a firm timeline on when their neighbourhood will receive designation as an HCD" (Heritage Toronto, 2019b, p. 20). With Agincourt's HCD in the distance, dwindling community support and no updated plan to complete a study in the area, there came new hope with the proposal of Midland Park HCD.

\subsection{HCD Case Study 2\#: Midland Park Heritage Conservation District}

Midland Park's HCD started its journey differently than Agincourt's HCD; it was resident centric from the beginning. Led by Lisa Duperreault, a resident of Midland Park, alongside a group of fellow residents known as Midland Park Modernism Alliance, which "Ms. Duperreault founded in 2011"(LeBlanc, 2015, 1. 7). The nomination of the "modernist heritage district" (Duperreault \& Midland Park Modernism Alliance, 2020b) was prompted by Ms. Duperreault's interest in learning more about her property and sharing her knowledge with the community. She expressed in a 2015 interview that "everyone knows they have something special [here], but they don't know why"(LeBlanc, 2015, 1. 7). Aligning with Ms. Duperreault's vision, the mandate of the Midland Park Modernism Alliance "is to be a resource with a mission for the documentation, preservation, and promotion of the mid-century modern houses of the Midland Park community" (Duperreault \& Midland Park Modernism Alliance, 2020b). Further, their "fundamental objective is to create awareness and build public appreciation and support for the distinctive historic character of this 1960s community”(Duperreault \& Midland Park Modernism Alliance, 2020b).

Midland Park, "by all accounts, is considered an architectural 'endangered species'"(Midland Park Modernism Alliance, 2015a, sec. What is so special about Midland Park?). Furthermore, "for 60-plus years, the modernist homes in Midland Park have stood 
essentially unaltered thanks to its residents who have respected the original modernist attributes, making it a Toronto rarity: an intact Atomic Age neighbourhood"(Duperreault \& Midland Park Modernism Alliance, 2020b).

Part of Ward 21, known as Scarborough Centre, Midland Park, is "located within the boundaries of Ellesmere Road, Midland Avenue, Donwood Park, and Birkdale Ravine Park"(Duperreault \& Midland Park Modernism Alliance, 2020a, sec. Area Map). The potential HCD contains "700 houses, suburban, award-winning development from 1959 - 1960 by [the Honourable] Paul Hellyer [former Canadian] MP, Wilf Curran - Ted Hall (Curran Hall developers) and Ted Ross (Architect)"(Scarborough Community Heritage Preservation Panel, 2014, p. 5). Mr. Hellyer was "elected to Parliament in 1949 at age 25, [and organized the] unification of the army, navy and air force in the mid-1960s as minister of national defence"(LeBlanc, 2005, 1. 2). He met with the founders of Curran Hall Ltd., "Wilf Curran and Ted Hall at the Granite Club, [and] he told them of the need for a 'General Motors of the housing industry" "(LeBlanc, 2005, 1. 4). Ultimately, he served as "president of Curran Hall Ltd. from 1950 until 1962”(LeBlanc, 2005, 1. 3).

Mr. Ross became the architect for Midland Park after, "Mr. Hellyer decided the company needed an in-house architect, so he [asked] Mr. Ross, ...to set up his drafting table at Curran Hall's offices at 1201 Bloor St. West"(LeBlanc, 2005, 1. 12). Mr. Ross had "attended Ontario College of Art on a scholarship before the war"(LeBlanc, 2006, 1. 25), then "served as a gunner in the Royal Canadian Artillery and arrived in Holland in the spring of 1945"(LeBlanc, 2006, 1. 23). After completing his duties in the Royal Canadian Artillery, he "enrolled at U of $\mathrm{T}$ to study mechanical engineering, but ultimately graduated with an architecture degree in 1949"(LeBlanc, 2006, 1. 26). 
On November 11th, 2014, at the Scarborough archives, the Scarborough Community Heritage Preservation Panel chair "circulated a request from the Midland Park Community Association to have the community designated as a Heritage Conservation District"(Scarborough Community Heritage Preservation Panel, 2014, p. 5). Due to the "limited material provided by the Midland Park Modernism Alliance [such as] ( site location, architectural styles, community uniqueness etc.), the Panel decided to provide tentative support to the community association and encourage their ongoing research"(Scarborough Community Heritage Preservation Panel, 2014, p. 5). Following the declaration of tentative support from the Scarborough Community Heritage Preservation Panel, the Midland Park Modernism Alliance and Ms. Duperreault spearhead an impressive number of community engagements, "starting with the creation of the website, midlandparktoronto.com"(LeBlanc, 2015, 1. 9). Beyond the website, they held an information booth at a local art festival called "Birkdale Art in the Park"(Midland Park Modernism Alliance, 2015a, sec. Upcoming Event) to share their enthusiasm for the potential heritage designation. They created an e-newsletter for the residents to share the historical significance of the houses in the area and provided updates surrounding their proposal to the City to residents. They encouraged residents to submit photos of their houses for the HCD proposal and created a street representative program for residents who wanted to deliver the "occasional brochure to houses on [the] street"(Midland Park Modernism Alliance, 2015, sec. Free Giveaway).

Ms. Duperreault even created various items of memorabilia, starting with "a reissue of the original Curran Hall brochure, featuring floor plans and original prices - "from $\$ 14,270$ to $\$ 17,930$ (which) was a hit with residents"(LeBlanc, 2015, 1. 15). Months before Ms. Duperreault's quest for heritage designation of Midland Park was proposed to the Scarborough Community Heritage Preservation Panel; there was another issue brewing among the residents. 
The issue provided more incentive for the community and residents to contribute their voices to the designation. The contentious issue was "an application to develop a 'McMansion' [in the area that] would tower over other homes, and set a dangerous precedent"(LeBlanc, 2015, 1. 12). To stand-up to the developers, Ms. Duperreault reached out to fellow residents and "within two weeks, a focus group of 25 "active community members" was formed to discuss both the HCD option and the public hearing for the "minor variance"(LeBlanc, 2015, 1. 13).

In the early months of 2015, Midland Park's local Councillor and one of Toronto's Deputy Mayor Michael Thompson, "facilitated a community meeting where the architect presented his plan for 10 Rosswood Crescent"(Midland Park Modernism Alliance, 2015a, sec. Property Variance Application Update), a section in Midland Park. Due to faults in architectural plans by the developer's architect, the residents dismissed the developer claims and "the architect agreed to visit the site... and meet with Rosswood neighbours later"(Midland Park Modernism Alliance, 2015a, sec. Property Variance Application Update) to make corrections and present new architectural plans. In follow-up meetings, residents noted that they had "the right to oppose [the structure] because of [its] negative effect on the neighbourhood and the precedent it will set on future redevelopment” (Midland Park Modernism Alliance, 2015a, sec. Property Variance Application Update).

They vowed to attend the "committee of Adjustment hearing... to have the opportunity to stand up and be heard"(Midland Park Modernism Alliance, 2015a, sec. Property Variance Application Update). They resoundingly presented " 350 plus petition signatures to the committee that represented about 300 homes"(LeBlanc, 2015, 1. 24). After the collection of the petitions, the development application was 'sine die'(LeBlanc, 2015, 1. 30) and "consultations between the property owner and concerned residents"(LeBlanc, 2015, 1.30) was mandated. The developer 
“ultimately soled the house”(Midland Park Modernism Alliance, 2016a, sec. Alert! New Property Variance Application) that was the intended spot of development without changing its appearance. After the community won the battle against the developer, "94\% of residents" (Midland Park Modernism Alliance, 2015, sec. Petition Signatures Count) agreed with the proposal to make Midland Park a designated area. Further, “50 residents”(LeBlanc, 2015, 1. 25) sent a letter to their "Councillor, City Planning Manager, (the) City Planner for Scarborough, and [the] Scarborough Heritage Preservation Committee"(Midland Park Modernism Alliance, 2015, sec. Petition Signatures Count) to give their support for the HCD designation.

By September 2015, Architourist and contributing writer to the Globe and Mail Dave LeBlanc had featured Midland Park in an article and the Chair of the Scarborough Community Heritage Preservation Panel "updated the committee on the community's effort to have Midland Park subdivision recommended for declaration as a Heritage Conservation District"(Scarborough Community Heritage Preservation Panel, 2015a, p. 3). Further, the chair noted that "the committee toured the proposed Conservation District on July 25, 2015, along with Ms.Duperreault and her husband "(Scarborough Community Heritage Preservation Panel, 2015, p. 3).

The Panel concluded that Midland Park should be under "consideration for designation as Scarborough's first Heritage Conservation District under Section V of the Ontario Heritage Act”(Scarborough Community Heritage Preservation Panel, 2015, p. 3). Further, one of the members of the Panel "Sandy Grigg agreed to be the committee's liaison with the Midland Park group and assist in moving the proposed HCD district forward" (Scarborough Community Heritage Preservation Panel, 2015, p. 3). In one of their e-newsletters, the Alliance noted that they received glowing support letters from the following: 
1. Rick Schofield, Chair Scarborough Heritage Preservation Committee

2. Honourable Paul Hellyer, Former Owner and President of Curran Hall and

Canada's former Minister of Defence

3. John Race Family, Former Curran Hall Executive- Secretary/Treasurer

4. Dave Leblanc, Architecture Journalist and mid-century modern expert

5. Salma Zahid, Member of Parliament for Scarborough Centre. (Midland Park Modernism Alliance, 2016a, sec. Heritage Conservation District Update)

In November 2015, the Alliance continued to rally, creating an official online store to sell Midland Park Vintage themed merchandise, so "all the proceeds go to Midland Park Heritage Conservation initiatives"(Midland Park Modernism Alliance, 2015b, sec. Now Open-Nov 16th !). All the designs for the items were created by the Alliance and over " 50 customizable products [such as]- shirts, aprons, mouse pads, pens, coasters and more are sold through their store"(Midland Park Modernism Alliance, 2015b, sec. Now Open-Nov 16th !). They also created a letter template so that residents could have a reference point when contacting their local Councillor Michael Thompson about their support for the heritage designation. In the same month, the Scarborough Community Heritage Preservation Panel chair noted that their HCD liaison and Ms. Duperreault "have shared various communications and report[ed] that the local committee appear[ed] to be moving ahead but would appreciate a 'check list' of HCD processes from Preservation staff "(Scarborough Community Heritage Preservation Panel, 2015, p. 4).

In February 2015, Toronto Heritage Preservation Services (HPS) was given a tour of Midland Park, and it was "well received" (Midland Park Modernism Alliance, 2016a, sec. City of Toronto Heritage Preservation Services Update). Still, their most prominent "challenge is 
getting Midland Park prioritized in the city's budget ahead of other neighbourhoods"(Midland Park Modernism Alliance, 2016a, sec. City of Toronto Heritage Preservation Services Update). Prioritization was not the Alliance's only challenge as a new issue brewed when the Alliance notified residents of a new variance application. The house in the application was "two stories, more than twice the square footage plus, the extra height of the roof "(Midland Park Modernism Alliance, 2016a, sec. Alert! New Property Variance Application).

Further, "the proposed design and materials of the new house did not fit in with the existing neighbourhood”(Midland Park Modernism Alliance, 2016a, sec. Alert! New Property Variance Application). The residents concluded that they would attend another "committee of adjustment hearing" as well as encourage residents to "send letters to the Committee of Appeals" (Midland Park Modernism Alliance, 2016a, sec. Let Our Voices Be Heard), so that the variance could be deferred. At the same time, the community could have the opportunity "to meet with the owner and discuss suggested design changes that fit in with the current look and feel of the neighbourhood"(Midland Park Modernism Alliance, 2016a, sec. Alert! New Property Variance Application).

Following the new variance, Ms. Duperreault presented the Scarborough Community Heritage Preservation Panel, with a "12-page (23 slide) presentation"(Scarborough Community Heritage Preservation Panel, 2016, p. 2). The presentation provided the committee with updates on the work the Alliance had done towards Midland Park HCD designation. Some of the key updates included the registering of:

Midland Park Modernism Alliance as a not-for-profit corporation, the creation of Midland Park modernist street signs at every entranceway into Midland Park, seeking 
placement of Midland Park as a tour in Doors Open Toronto 2017, [and the] creation of a social media page. (Scarborough Community Heritage Preservation Panel, 2016, p. 2) In November 2016, the Alliance noted that “Midland Park's bid for a Heritage Conservation Study is currently under review (and that) final decisions on new HCD studies in the City of Toronto for 2017/18 are supposed to be finalized by the end of this year"(Midland Park Modernism Alliance, 2016b, sec. Canada Modernism Conservation). In June 2017, at a Scarborough Community Heritage Preservation Panel meeting, a guest speaker, identified as a "City staff personnel working in Preservation Services"(Scarborough Community Heritage Preservation Panel, 2017a, p. 3) provided an update. They noted that "over ten districts are currently being assessed with many others, including Midland Park, waiting for inclusion in [the] queue"(Scarborough Community Heritage Preservation Panel, 2017a). Further, the chair updated the Panel on Midland Park HCDs, citing a report from the Midland Park HCD committee outlining its very successful "Doors Open Tour and the recent nomination approval from Heritage Toronto for inclusion in its 43rd Annual awards selection under the Community Heritage category" (Scarborough Community Heritage Preservation Panel, 2017a, p. 3).

In November 2017, A Prioritization of Outstanding Heritage Conservation District Studies and Interim Protective Measures Report noted that Midland Park was among "five areas that have been nominated by community groups and these nominations are in various states of readiness and are under City staff review"(Acting Chief Planner and Executive Director, City of Toronto Planning Division, 2017, p. 9). They further noted that "completed nominations will be brought forward to council for consideration and authorization on a case by case basis. Until that time, these nominations are excluded from the prioritization process"(Acting Chief Planner and Executive Director, City of Toronto Planning Division, 2017, p. 9). 
In December 2017, the Scarborough Community Heritage Preservation Panel expressed their weariness, noting that "Midland Park alongside Agincourt HCD had been on the agenda for many years but with no positive action to move either forward"(Scarborough Community Heritage Preservation Panel, 2017b). In January 2018, Midland Park made more strides becoming:

registered as a modern residential neighbourhood in the province of Ontario, recognized as part of Ontario's built legacy of the modern movement by the International Society for the Documentation and Conservation of buildings, sites and neighbourhoods of the Modern Movement (DOCOMOMO). (Midland Park Modernism Alliance, 2018, sec. Special Announcement)

The Scarborough Community Heritage Preservation Panel was pleased with the announcement stating, "hopefully, this new recognition will assist in the future designation of the community"(Scarborough Community Heritage Preservation Panel, 2018a, p.2). Their enewsletter further noted that their HCD "nomination was still under review"(Midland Park Modernism Alliance, 2018, sec. Midland Park Heritage Conservation District (HCD) 30 Second Update). In February 2018, positive news was shared at the Scarborough Community Heritage Preservation Panel when the chair noted that the "Toronto Preservation Board approved a staff recommendation to prioritize the outstanding HCDs"(Scarborough Community Heritage Preservation Panel, 2018a, p. 2). At the meeting, the chair noted that in the past year, the committee recommended that Heritage Preservation staff give priority to creating an HCD in Scarborough ... (and) further that Midland Park be given more consideration as it has the full support of the local community"(Scarborough Community Heritage Preservation Panel, 2018a, p. 2). 
Sandy Grigg, Midland Park's liaison, echoed that the Scarborough Community Heritage Preservation Panel was informed, prior to the February 2018 meeting "that little action had been taken on the recommendation to designate Midland Park as a Heritage Conservation District (but), the Midland Park committee will seek more support during the upcoming municipal elections to move this recommendation forward" (Scarborough Community Heritage Preservation Panel, 2018b, p. 2).

The slow movement of Midland Park's HCD designation did not stop it from being featured in Tourism Toronto's 2019 magazine, which highlighted the City's unique architectural communities. When discussing Midland Park, the magazine article (see Figure 11) noted that "a wander along Birkdale Road is like stepping back into the optimistic Space Age vision of the suburbs"(Bradburn, 2019, p. 36). In 2020, no updates were provided in the Midland Park Modernism Alliance Newsletter, and Ms.Duperreault made no statements about the HCDs status. However, the Midland Park Toronto website still states that the HCD "nomination is currently under review by the City of Toronto"(Duperreault \& Midland Park Modernism Alliance, 2020b). Potential HCDs in Scarborough seem to be up in the air, leaving the area vacant of a major district of heritage conservation that is deemed cultural and historically valuable. Both case studies have demonstrated the flaws in the HCD designation process that places communities in heritage designation limbo. In the following section, I will provide four recommendations for the City of Toronto to consider when addressing the disproportionate designation of HCDs. 


\section{Figure 11}

\section{Tourism Toronto Article on Midland Park HCD}

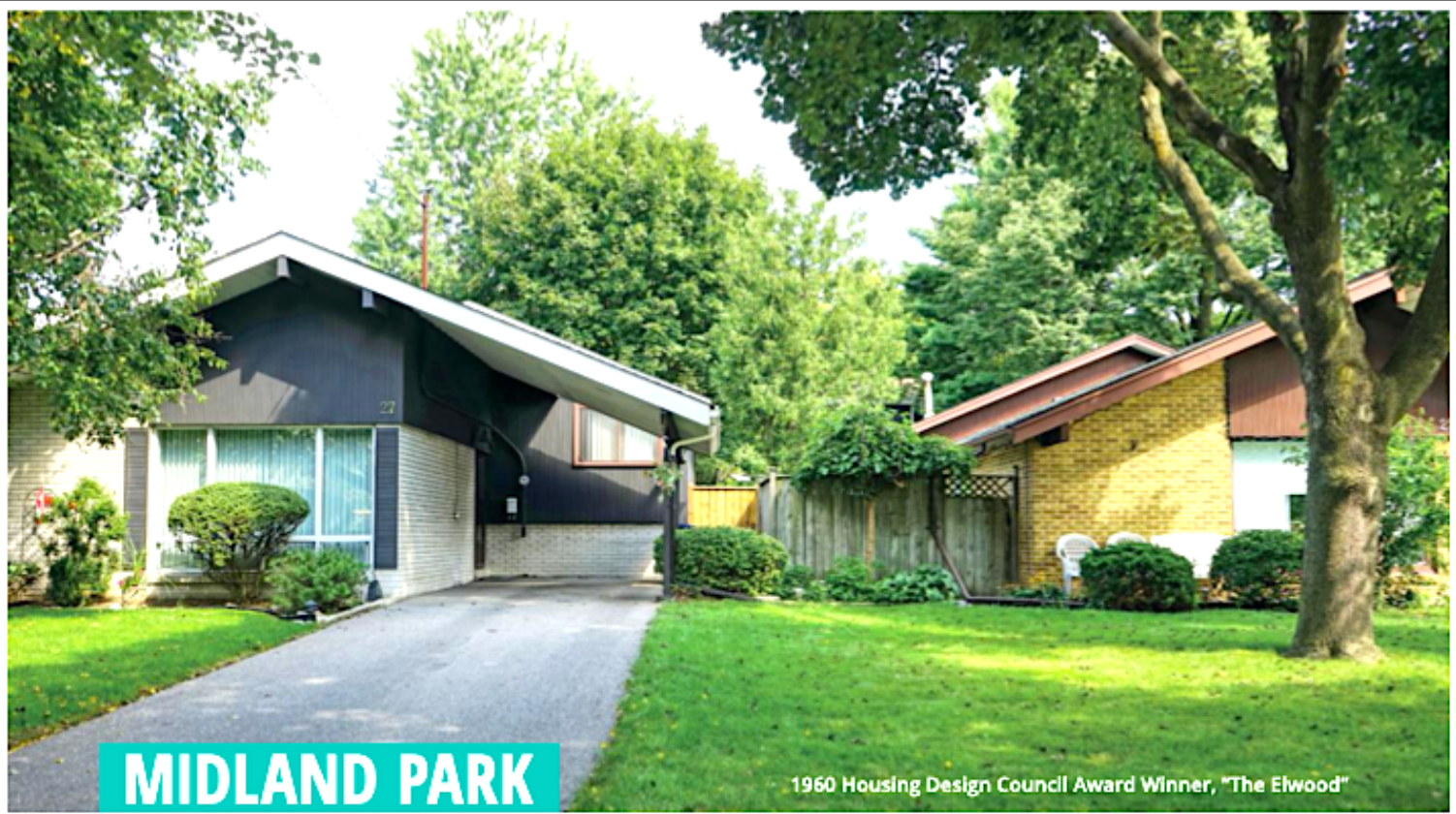

A

half century after its $\mid$ execs at the time. (Though large first homes were built, for the time, the properties are - this Searborough neighbourhood in Toronto's east end stands as an extraordinary, largely intact example of modernist design geared at the ambitious young families of the 1950 s and ' 60 s. A wander along Birkdale Road is like stepping back into the optimistic Space Age vision of the suburbs, with modestly sized back-split and side split bungalows set among old.growth trees. The woody cozy by today's MeMansion standards. Based on a 1960 sales brochure, homes ranged from 1,123 to 1,627 square feet depending on the model.

Original buyers chose from 12 designs of bungalows offering sloping triangular roofs, carports, and plain fronts without porches. Potential homeowners were won over by large living rooms, separate dining rooms, bright kitchens, extra bathrooms, and

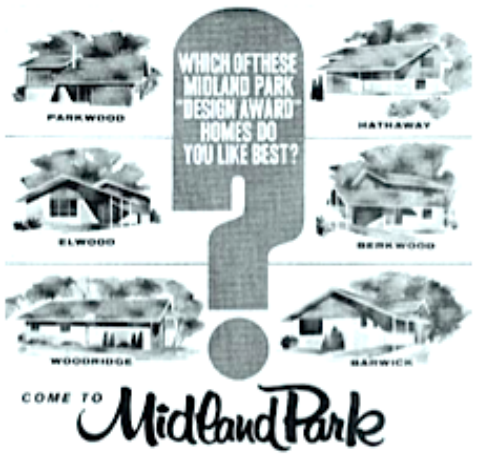

Note: Screengrab of Tourism Toronto's Article on Midland Park from their Annual Magazine, 2019.

\subsection{Recommendations}

\section{Recommendation 1:}

To remedy the disproportionate nature of Heritage Conservation Districts, a standalone plan is needed to combat the key challenges that affect the creation of HCDs in the first five years of initiating and delivering the City program. Highlighted by Acting Chief Planner And 
Executive Director of City planning in Toronto Gregg Lintern in 2018, the key challenges include:

1. The need for user-friendly communication tools that engage with a broad demographic to demystify the HCD process.

2. The complexity of multi-year project management which hinders the delivery of HCDs.

3. The lack of business practice tools to execute the administrative activities of HCDs.

4. The time consuming and complex nature of preparing interim protective measures.

5. Future enhancements to capital and the capacity of staff due to the significant increase of building permit reviews and development applications.(Chief Planner and Executive Director, 2018, pp. 3-6)

If creating this plan becomes the first step, then the City of Toronto is well on its way to combating the disproportionate designation and distribution of heritage conservation districts.

\section{Recommendation 2:}

To remedy the misinformation and lack of City-wide education on the value of heritage conservation, it is recommended that the City of Toronto utilize their four community councils and create both physical and digital HCD designation kits, to eradicate the social, historical and economic factors affecting the community's involvement in HCDs. The kits should contain the frequently asked questions (FAQ) HCD document that the City currently has created but should also include info cards that can provide condensed information on the following areas funding, fundraising, community advocacy, councillor collaboration tactics, key persons of contact, legal obligations, relevant legislation and estimated designation timeframes.

\section{Recommendation 3:}


With increased heritage designation comes more costs. These costs can be associated with Cultural Heritage Resource Assessments(CHRA), heritage planning studies, multiple staging of community and sector consultations, as well as the cost of educational material and increased staffing. Therefore, the City should consider its 2006 proposal to engage "the financial sector to identify mechanisms to leverage financial resources and mitigate the risks of conservation"(City of Toronto, Heritage Preservation Services, 2007, p. 59). This, in turn, could help to provide stronger funding mechanisms for HCD study plans, so that delays in heritage conservation can be addressed.

\section{Recommendation 4:}

Among the HCD stages of designation, there are many instances of citizen consultation but not as many opportunities for citizen participation. Therefore, it is recommended that the City consider a co-production approach which "has [the] potential for building resilient and sustainable cities, but...requires an institutional transformation to overcome resistance to power redistribution and to [further] enhance the planning process in terms of inclusivity and equity"(Ruiz-Mallén, 2020, p. 9). This approach will help to assist residents of a chosen district with the successful designation of an HCD and promote the practice of identifying "those who are usually treated more as observers than actors in policy-making processes, ...giving them a voice by opening up spaces for participation and reflexivity”(Ruiz-Mallén, 2020, p. 9). 


\section{Chapter Six: Conclusion}

\subsection{HCDs in Toronto: Planning, Pause and Potential}

In conclusion, this MRP has demonstrated that many factors contribute to the disproportionate designation of Heritage Conservation Districts. As noted in the recommendations above, there are tangible solutions that can effectively address these factors in the City of Toronto. Reflecting on the first key research question in section 1.3.1 of this MRP, which seeks to determine the factors that affect HCDs, one can conclude that the factors are:

- The complexity of the HCD designation process.

- Lengthy designation and study timeframe.

- The interwoven nature of provincial heritage and planning policies, which can hinder the power of municipalities when making heritage conservation decisions.

- The uneven designation of heritage properties in the inner suburbs.

- The lack of engagement tools that can enhance public education on the benefits of heritage and;

- The incremental nature of Heritage conservation during the post-amalgamation period.

As highlighted throughout this MRP, planning legislation and heritage policy go hand in hand. With the recent changes to the Ontario Heritage Act, the Ontario Municipal Board, and the Provincial Policy Statement, it has become increasingly important for the Ontario government to work with the heritage sector to account for current and future land-use trends, which relate to heritage conservation. As the City notes:

an incremental and reactive approach to the evaluation of properties for inclusion on the Heritage Register has resulted in significant challenges [as] unidentified properties with 
potential cultural heritage value have been lost, and disputes between the community and owners have arisen over what properties should be preserved. (City of Toronto-Chief Planner and Executive Director, City Planning Division, 2019, p.5)

Reflecting on the second key research question which inquirers about the relationship between HCDs and heritage properties, one can confirm that heritage properties' incremental nature feeds directly into the low designation of Heritage Conservation Districts. Further, it is clear that citizen opposition to the heritage designation process and the lack of accessible educational resources on the HCD process stand as major issues when increasing heritage property numbers. Under the current system, "property owners may receive a rebate of $50 \%$ of the cost of eligible maintenance and conservation work up to $40 \%$ of annual taxes paid" (Heritage Toronto, 2019, p. 17) but "only $66 \%$ of Torontonians are aware that heritage buildings are eligible for grants and tax rebates"(Heritage Toronto, 2019, p. 16).

Further, Heritage Toronto notes that in a "July 2018 public heritage forum, there were numerous calls to both clarify what HCDs are and what value they hold for the individual property holder (in addition to the) local communities" (Heritage Toronto, 2019, p. 18). From these statistics, one can determine that public education resources on heritage conservation are essential to its success as a planning tool. In phase one of the City-Wide Heritage Survey (see Figure 12), both heritage property and public engagement are proposed to be addressed. The City notes that "priority will be given to the triage and evaluation of over 300 properties that have already been nominated by City Council and the public for inclusion on the Heritage Register" (City of Toronto-Chief Planner and Executive Director, City Planning Division, 2019, p. 10). 


\section{Figure 12}

City Wide Heritage Survey Phased Work Plan Chart (2019-2022)

City-Wide Heritage Survey Feasibility Study

Attachment 3: Phased Work Plan (2019-2022)

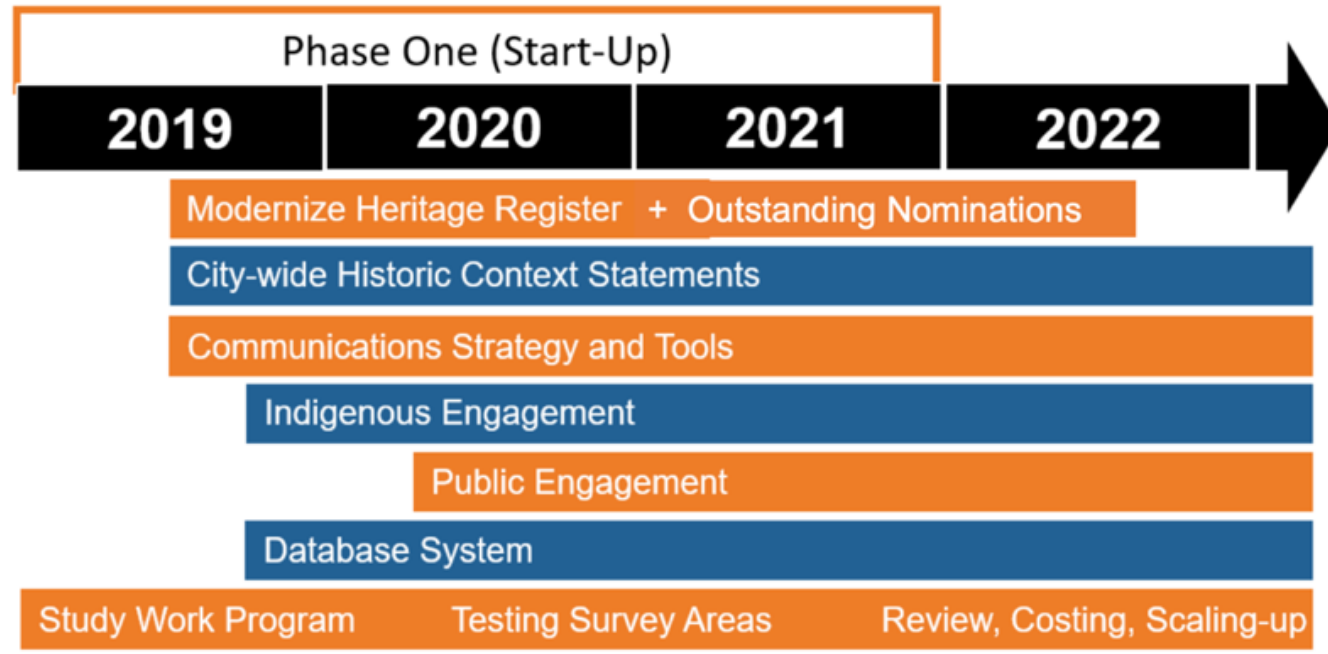

Note: Adapted from the City of Toronto's 2019 City Wide Heritage Survey Feasibility Study Report 2019.

Further, "properties identified ... as having cultural heritage value will be added to a

Toronto Heritage Survey map layer [which will] allow the general public, property owners, and City staff to quickly identify properties with cultural heritage value"(City of Toronto-Chief Planner and Executive Director, City Planning Division, 2019, p. 13). In regards to public engagement, City staff "have employed a range of tools aimed at reaching diverse stakeholders across the city with varied interests in heritage preservation"(City of Toronto-Chief Planner and Executive Director, City Planning Division, 2019, p. 8), through the City-Wide Heritage Survey process. These "consultations ... have included a public event, over 30 individual meetings, and an online questionnaire"(City of Toronto-Chief Planner and Executive Director, City Planning Division, 2019, p. 8). In addition, the City is said to be exploring "technology resources and tools 
needed to enhance its [heritage] services"(City of Toronto-Chief Planner and Executive Director, City Planning Division, 2019, p. 10). This includes "automating heritage nominations, building application and tracking systems, improving visualization of and access to the Heritage Register, and cleaning up and geo-locating internal research and data storage systems"(City of TorontoChief Planner and Executive Director, City Planning Division, 2019, p. 9). Returning to the case studies discussed in this MRP, the historical precedent of HCDs in the post amalgamation period has affected the designation of districts outside the downtown core. One can also determine that the HCD process has placed heritage designation in Scarborough within a perpetual state of limbo. This limbo goes beyond heritage planning and extends to planning in Ontario. Freeman (2015) notes:

the major problem with the planning process, as it is practiced in the GTHA, is that landuse planning serves the needs of the developers, not the public....We have a development approvals system, not a planning system (and) local councillors, city planners, and the public are forced to look at each new application in isolation, always with the concern that the OMB can overturn their decision. (p. 113)

As noted earlier in this MRP, Heritage Conservation Districts (HCDs) are defined as a planning tool that "guides change in neighbourhoods, that represent Toronto's rich social, cultural and architectural history (and that) contributes to the livability and appeal of Toronto as a multicultural, sustainable and equitable city"(City of Toronto-Heritage Preservation Services, 2020). Further, considering the tenets that critical race theory, settler-colonialism, and critical urban theory provide, it would be beneficial for the City to prioritize equity and social justice principles in their use of HCDs as a planning tool, especially with the highly diverse ethno-racial demographics of inner suburban areas in Toronto. These tenets can also reinforce the City's goal 
to use HCDs as a mechanism to contribute to the City's multicultural and equitable persona. As Sandercock notes, "the multicultural city cannot be imagined without a belief in inclusive democracy and the diversity of social justice claims of the disempowered communities in existing cities"(Sandercock, 1998, p. 30). She further suggests that "if we want to work toward a policy of inclusion, then we had better have a good understanding of the exclusionary effects of planning's past practices and ideologies"(Sandercock, 1998, p. 30).

The striking differences in Agincourt and Midland Park's HCD designation nomination, the nearly opposite reaction in citizen engagement, and the variances in political support did not reflect the City's HCD goals, subsequently maintaining the status quo for heritage conservation in Scarborough. Further, by utilizing the three concepts of 'engagement' that Rowe and Frewer propose which are (public communication, public consultation, and public participation) and help "differentiate initiatives [that] have in the past been referred to as public participation (alone), based on the flow of information between participants and sponsors"(Rowe \& Frewer, 2005 , p. 254). One can see the disparities in engagement between the case studies within Scarborough and those in other suburban areas of the City. Further, considering engagement alone, HCDs in Scarborough have mixed levels of the three concepts of engagement, whereas Etobicoke (another inner suburban area of Toronto that successfully attained an HCD in 2006, had identical levels among the three concepts, which I have included in Table 8. 
Table 8

Heritage Conservation Districts Case Study Comparison

\begin{tabular}{|c|c|c|c|}
\hline Case Studies & Initiated & Approach & Results \\
\hline $\begin{array}{l}\text { Agincourt } \\
\text { HCD }\end{array}$ & $\begin{array}{ll}\text { - } & \text { Year - } 2005 \\
\text { - Organization- } \\
\text { Scarborough } \\
\text { Community } \\
\text { Preservation } \\
\text { Panel (Heritage } \\
\text { Community } \\
\text { Council) }\end{array}$ & $\begin{array}{l}\text { - Standard engagement } \\
\text { mechanisms were } \\
\text { utilized by City } \\
\text { representatives, i.e. } \\
\text { public consultation, } \\
\text { Panel discussions } \\
\text { - } \quad \text { No unique engagement } \\
\text { mechanism were used } \\
\text { - Not resident-centred } \\
\text { - Largely top down } \\
\text { - Medium levels of public } \\
\text { communication } \\
\text { - Medium levels of public } \\
\text { consultation } \\
\text { Low levels of public } \\
\text { participation }\end{array}$ & $\begin{array}{l}\text { - City Council's } \\
\text { authorization for } \\
\text { Agincourt to be } \\
\text { studied as a potential } \\
\text { HCD designation is } \\
\text { no longer active but } \\
\text { still viable } \\
\text { City Council's } 2017 \\
\text { cultural heritage } \\
\text { resource assessment } \\
\text { (CHRA) request was } \\
\text { placed on hold in } \\
\text { 2020 } \\
\text { Agincourt's HCD } \\
\text { designation has } \\
\text { ceased to be } \\
\text { mentioned in } \\
\text { municipal planning } \\
\text { documents } \\
\text { No longer actively } \\
\text { supported by the } \\
\text { Scarborough } \\
\text { Community } \\
\text { Preservation Panel } \\
\text { (Heritage } \\
\text { Community Council) }\end{array}$ \\
\hline $\begin{array}{l}\text { Midland } \\
\text { Park HCD }\end{array}$ & $\begin{array}{l}\text { Year- } 2015 \\
\text { Organization- } \\
\text { Midland Park } \\
\text { Modernism } \\
\text { Alliance } \\
\text { (Community } \\
\text { Association) }\end{array}$ & $\begin{array}{l}\text { - Standard engagement } \\
\text { mechanisms were } \\
\text { utilized by City } \\
\text { representatives, i.e. } \\
\text { public consultation, } \\
\text { Panel discussions } \\
\text { - Unique engagement } \\
\text { mechanisms were } \\
\text { utilized by Midland Park } \\
\text { Modernism Alliance .ie. } \\
\text { public consultation, } \\
\text { website, social media, } \\
\text { digital publication, } \\
\text { online store community } \\
\text { activities }\end{array}$ & $\begin{array}{l}\text { - City Council hasn't } \\
\text { approved Midland } \\
\text { Park as a potential } \\
\text { designation area of } \\
\text { study } \\
\text { - Midland Park HCD } \\
\text { creation has ceased } \\
\text { to be mentioned in } \\
\text { municipal planning } \\
\text { documents }\end{array}$ \\
\hline
\end{tabular}




\begin{tabular}{|c|c|c|c|}
\hline & & $\begin{array}{ll}\text { - } & \text { Resident centred } \\
\text { - } & \text { Largely bottom up } \\
\text { - } & \text { Medium levels of public } \\
\text { communication } \\
\text { - } & \text { High levels of public } \\
\text { consultation } \\
\text { - } \\
\text { High levels of public } \\
\text { participation }\end{array}$ & \\
\hline $\begin{array}{l}\text { Weston } \\
\text { HCD } \\
\text { Phase } 1\end{array}$ & $\begin{array}{l}\text { Year- } 2003 \\
\text { Organization } \\
\text { Weston Historical } \\
\text { Society }\end{array}$ & $\begin{array}{l}\text { Standard engagement } \\
\text { mechanisms were } \\
\text { utilized by City } \\
\text { representatives, i.e. } \\
\text { public consultation, } \\
\text { Panel discussions } \\
\text { - Unique engagement } \\
\text { mechanisms were } \\
\text { utilized by the Weston } \\
\text { Historical Society i.e. } \\
\text { public consultation, } \\
\text { website creation } \\
\text { Resident-centred } \\
\text { Largely bottom up } \\
\text { High levels of public } \\
\text { communication } \\
\text { High levels of public } \\
\text { consultation } \\
\text { High levels of public } \\
\text { participation }\end{array}$ & $\begin{array}{l}\text { - Successfully adopted } \\
\text { in } 2006 \\
\text { By-law 798-2006, } \\
\text { was appealed by a } \\
\text { local property owner } \\
\text { in } 2006 \\
\text { - In } 2007 \text { three by- } \\
\text { laws were amended } \\
\text { in Weston's HCD, as } \\
\text { a result of the appeal }\end{array}$ \\
\hline
\end{tabular}

Note: Adapted from the City of Toronto's Heritage Preservation Services on data on HCDs, 2020.

Phase one of Weston's HCD was initiated in 2003 by the "Weston Historical

Society"(Manager-Heritage Preservation Services \& Gendron, 2006, p. 2). At the time, "the

Weston Historical Society [had] become concerned about the potential [of] deterioration in the heritage character of their community"(Davies \& City of Toronto-Clerks Office, 2004, p. 2). On April 8, 2004, the Toronto Preservation Board "considered a report...from the Commissioner of Economic Development, Culture and Tourism seeking authority to study the Weston area for potential designation under Part V of the Ontario Heritage Act as a Heritage Conservation 
District"(Davies \& City of Toronto-Clerks Office, 2004, p. 1). In 2006, the "Designation of a part of the former Town of Weston as a Heritage Conservation District under Part V of the Ontario Heritage Act (Ward 11-York South-Weston) was approved and adopted by City Council without amendment”(City of Toronto-Heritage Preservation Services \& Gendron, 2006, p. 1).

From the successful result of this designation, one can conclude that the historical society's leadership helped to cement the cultural and historical value of the area, which is a critical aspect of the designation process under Ontario Regulation 9/06. In addition, the support from the Etobicoke Community Council and the creation of the "Weston Heritage Conservation District Board... composed of interested Weston residents"(Manager-Heritage Preservation Services \& Gendron, 2006, p. 3), also contributed to the HCD's success. Still, since 2006, Weston's heritage designation formula had not been replicated in the area, but in "January 2018”(Heritage Preservation Services-City of Toronto, 2020, para. 1), the City noted that it would prioritize Weston HCD Phase II and is currently in the process of conducting a study of the potentially expanded HCD area, with a pre-pandemic target of completion in Fall 2020.

The inclusion of Weston's HCD as a comparative case study to the HCDs in Scarborough highlights that even when a formula for designation success exists in one suburban area of the City, there are still no guarantees that it can be applied to another similar area. Further, considering the similarities in Midland Park's HCD and Weston's HCD engagement approaches, it's clear that a heritage designation's potential success is not solely predicated on high or medium levels of engagement. However, it does stand as a significant component. Also, it seems that connections between the leaders of the nomination of a potential designation area and their established relationship with the residents of a given community are of substantial significance but also not the magic ingredient. Moreover, even if the efforts of a nominator, the community 
and external organizational supporters are all alined and no division, opposition or LPAT appeals occur, then the success of a potential HCD designation can all be superseded by the agenda of the City planning division in at any given time period. The priorities of the City on heritage conservation can change in an instant, and if the tide is swayed in the direction of the downtown core instead of the inner suburbs, then the benefits of HCDs will continue to be devoid in Scarborough. The takeaway is that beyond the City's HCD designation process and prioritization criteria, there needs to be better political will from local councillors, accessible tools for continuous citizen engagement and stronger funding mechanisms for HCD study plans so that delays in heritage conservation can be addressed.

Further, there seems to be an unspoken factor in heritage designation that affects the City's inner suburbs, which point to the long economic discrepancies that many residents face (See Hulchanski's (2010) article, The Three Cities Within Toronto for more details). As Freeman suggests, although "some communities (in the inner suburbs) are high-income neighbourhoods...incomes, on average, are considerably lower ... than either the downtown or the outer suburbs"(Freeman, 2015, p. 31). The social and economic inadequacies of HCD designation in Toronto are echoed in a Torontoist article that states, "the current system overwhelmingly favours older, upper-middle-class people who live in developing neighbourhoods and possess both the time and disposable income to see the process through to the end"(Torontoist, 2015, 1. 15). The article further notes that "high-turnover neighbourhoods, low-income neighbourhoods, and neighbourhoods that are not easily walkable see more barriers from participation. As a result, Toronto's HCDs tend to be concentrated in the City's wealthier neighbourhoods"(Torontoist, 2015, 1. 16). 
These inadequacies have yet to be addressed by Toronto Heritage Preservations Service's (HPS), but the discussion of the prioritization systems effectiveness relates back to the third and final key research question posed in this MRP, which asks how the prioritization system can better serve the HCD designation process. In direct response to this, City staff have noted that they aimed to refine the system "through consultation with the Toronto Planning Review Panel ... and the Technical Expert Panel...”(City of Toronto-Chief Planner and Executive Director, City Planning Division, 2019, p. 10). In addition:

data sets are now being acquired and analyzed by City staff to understand which might best serve the prioritization process (and) with Council's endorsement, City staff will bring both the draft criteria and the multi- criteria evaluation tool to stakeholders and the public for consultation.(City of Toronto-Chief Planner and Executive Director, City Planning Division, 2019, p. 10-11)

City staff also note that "the results of this prioritization approach would inform which areas are surveyed first as the program scales up in 2021 and 2022"(City of Toronto-Chief Planner and Executive Director, City Planning Division, 2019, p. 11). Aside from the reform of the prioritization system, after Phase one is completed, "City staff propose to advance the survey using neighbourhood boundaries that the City of Toronto currently (use) for other statistical and planning purposes, as defined according to Statistics Canada census tracks"(City of TorontoChief Planner and Executive Director, City Planning Division, 2019, p. 9).

Although there is little mention of HCDs specific plans in the City-Wide Heritage Survey, there is promise in the expansion of heritage conservation surveying beyond the downtown core, which will help with the identification of new areas of heritage cultural value, directly benefiting HCD designation. This includes the notion that HCDs cultural heritage value can "be expressed 
more broadly as natural, historic, aesthetic, architectural, scenic, scientific, cultural, social or spiritual"(City of Toronto-Heritage Preservation Services, 2019, p. 23).

Clearly, the benefits out way the risk and Heritage Preservation Services (HPS) should continue to champion HCDs so that heritage can be represented in all areas of the City. Further, with the impending changes to the City of Toronto manual on HCDs, as per Bill 108, it is clear that the time is now for the City to move from a reactive to a proactive model. The City's precedent of incrementally addressing the issues surrounding HCDs will not suffice, as this approach has not produced the heritage designation results that are reminiscent of a world-class City such as Toronto. 


\section{REFERENCES}

Acting Chief Planner and Executive Director, City of Toronto Planning Division. (2017). Prioritization of Outstanding Heritage Conservation District Studies and Interim Protective Measures (p. 23). City of Toronto, Planning Division.

Bandarin, F., Oers, R. van, \& Bandarin, F. (Eds.). (2015). Reconnecting the city: The historic urban landscape approach and the future of urban heritage. John Wiley \& Sons Inc.

Barrett, S. (2012). Heritage Conservation Districts in Toronto:Procedures,Policies and Terms of Reference (M. MacDonald, Ed.). City of Toronto, City Planning Division. https://www.toronto.ca/legdocs/mmis/2012/pg/bgrd/backgroundfile-44992.pdf

Bolay, J.-C. (2020). Global Sustainability: How to Rethink Urban Planning. In J.-C. Bolay (Ed.), Urban Planning Against Poverty: How to Think and Do Better Cities in the Global South (pp. 57-82). Springer International Publishing. https://doi.org/10.1007/978-3-030-28419$0 \_3$

Bonds, A., \& Inwood, J. (2016). Beyond white privilege: Geographies of white supremacy and settler colonialism. Progress in Human Geography, 40(6), 715-733. https://doi.org/10.1177/0309132515613166

Bozikovic, A. (2019, July 18). Toronto city council wants city planners to look into new forms of development within neighbourhoods. The Globe and Mail (Online). Global Newsstream. http://ezproxy.lib.ryerson.ca/login?url=https://search.proquest.com/docview/2382271719 ?accountid $=13631$

Bradburn, J. (2019). PERIOD PERFECT. Tourism Toronto, 96. 
Brenner, N. (2009a). Chapter 2- What is Critical Urban Theory? In Cities For People, Not For Profit-Critical Urban Theory and The Right to The City (Vol. 13, pp. 198-207). https://www.tandfonline.com/doi/full/10.1080/13604810902996466

Brenner, N. (2009b). What is critical urban theory? City, 13(2-3), 198-207. https://doi.org/10.1080/13604810902996466

Brenner, N., Marcuse, P., \& Mayer, M. (2011). Chapter 1 Introduction-Cities For People, Not For Profit. In Cities For People, Not For Profit-Critical Urban Theory and The Right to The City (p. 10).

Campbell, H., Tait, M., \& Watkins, C. (2014). Is There Space for Better Planning in a Neoliberal World? Implications for Planning Practice and Theory (S. S. Fainstein \& J. DeFilippis, Eds.; Fourth Edition, Vol. 34, pp. 187-213). John Wiley \& Sons, Ltd.

CBC News. (2010, December 16). Toronto councillors kill car tax, cut budgets. CBC News. https://www.cbc.ca/news/canada/toronto/toronto-councillors-kill-car-tax-cut-budgets1.883783

Chianello, J. (2017, May 17). Why changes to the OMB may force council to own its planning decisions. $C B C$ News. https://www.cbc.ca/news/canada/ottawa/omb-changes-ottawa-citycouncil-planning-decision-1.4117153

Chief Planner and Executive Director. (2011). Heritage Conservation Districts in Toronto: Procedures, Policies and Terms of Reference (p. 8). City of Toronto.

Chief Planner and Executive Director. (2012). Toronto Heritage Conservation District (HCD) Study Prioritization Report (p. 34). City of Toronto. 
Chief Planner and Executive Director. (2018). Supplementary Report: Prioritization of Outstanding Heritage Conservation District Studies and Interim Protective Measures ( $\mathrm{p}$. 6). City of Toronto.

Chief Planner and Executive Director, City Planning. (2015). Toronto Heritage Conservation District (HCD) Study Prioritization (p. 10). City of Toronto.

Chief Planner and Executive Director, City Planning. (2018). PG31.8 City Planning DivisionStudy Work Program Update (p. 28). City of Toronto.

Chief Planner and Executive Director, City Planning. (2020). City Planning Division - Study

Work Program PH12.3 (p. 32). City of Toronto, Planning Division.

Chief Planner and Executive Director, City Planning Division. (2015). Toronto Heritage

Conservation District (HCD) Study Prioritization Report (p. 10). City of Toronto.

Chief Planner and Executive Director, City Planning Division. (2017). Update on Heritage

Studies (p. 16). City of Toronto.

City Manager and Chief Planner and Executive Director, City Planning. (2019). Proposed Bill 108 (More Homes, More Choice Act, 2019) and the Housing Supply Action PlanPreliminary City Comments-CC7.3 (p. 35). City of Toronto.

City of Guelph. (2018). City of Guelph - Cultural Heritage Action Plan Background Report (p. 87). City of Gulph.

City of Toronto. (2009a). Staff report for action on Relationship Framework with Heritage Toronto (p. 7). City of Toronto. https://www.toronto.ca/legdocs/mmis/2009/ex/bgrd/backgroundfile-23746.pdf 
City of Toronto. (2009b). Relationship Framework For City of Toronto With Heritage Toronto

(p. 21). City of Toronto. https://www.toronto.ca/wp-content/uploads/2017/08/96b2-

Relationship-Framework_New-LOGO.pdf

City of Toronto. (2019a). The Land Acknowledgement (p. 9). City of Toronto.

https://www.toronto.ca/wp-content/uploads/2019/06/90c6-2019-Land-AcknowledgmentGuidance.pdf

City of Toronto. (2019b). Toronto Municipal Code Chapter 103, Heritage (p. 27). City of

Toronto. https://www.toronto.ca/legdocs/municode/1184_103.pdf

City of Toronto. (2019c, May 14). Proposed Bill 108 (More Homes, More Choice Act, 2019) and the Proposed Housing Supply Action Plan-Preliminary City Comments-CC7.3.

Toronto.Ca. http://app.toronto.ca/tmmis/viewAgendaItemHistory.do?item=2019.CC7.3

City of Toronto. (2019d). TORONTO FACT SHEET: Development Charges.

https://www.toronto.ca/wp-content/uploads/2019/05/97e8-CP-TorontoFactSheetdevelopment-charges.pdf

City of Toronto. (2020a). 2020 Budget Notes City Planning. City of Toronto, City Planning Division.

City of Toronto. (2020b). Heritage Toronto. https://www.toronto.ca/citygovernment/accountability-operations-customer-service/city-administration/citymanagers-office/agencies-corporations/agencies/heritage-toronto/

City of Toronto, \& General Manager, Economic Development and Culture. (2019). Investments in Culture (p. 8). City of Toronto.

City of Toronto, Heritage Preservation Services. (2007). The Heritage Management Plan (p. 108) [Government]. City of Toronto, Heritage Preservation Services. 
City of Toronto, Heritage Preservation Services. (2008). Toronto Preservation Board Minutes PB16.4 (p. 9). City of Toronto.

City of Toronto, Heritage Preservation Services. (2020a). Heritage Grant Program. Toronto.Ca. https://www.toronto.ca/city-government/planning-development/heritage-preservation/taxrebates-grants/heritage-grant-program/

City of Toronto, Heritage Preservation Services. (2020b). Heritage Tax Rebate \& Grant Programs Share. Toronto.Ca. https://www.toronto.ca/city-government/planningdevelopment/heritage-preservation/tax-rebates-grants/

City of Toronto, Heritage Preservation Services. (2020c). Heritage Tax Rebate Program. Toronto.Ca. https://www.toronto.ca/city-government/planning-development/heritagepreservation/tax-rebates-grants/heritage-tax-rebate/

City of Toronto, Lintern, G., \& Troian, D. (2018). City Planning 2018 - 2027 Capital Budget and Plan Overview. City of Toronto, City Planning Division.

City of Toronto-Chief Planner and Executive Director, City Planning Division. (2019). CityWide Heritage Survey Feasibility Study PH 7.11 (p. 25). City of Toronto.

City of Toronto-Heritage Preservation Services. (2019). Overview: City-wide Heritage Survey Feasibility Study. https://www.toronto.ca/city-government/planningdevelopment/heritage-preservation/city-wide-heritage-survey-feasibility-study/city-wideheritage-survey-feasibility-study-overview/

City of Toronto-Heritage Preservation Services. (2020). Heritage Register [Government]. Toronto.Ca. https://www.toronto.ca/city-government/planning-development/heritagepreservation/heritage-register/ 
City of Toronto-Heritage Preservation Services, \& Gendron, D. (2006). Designation of a part of the former Town of Weston as a Heritage Conservation District under Part V of the Ontario Heritage Act (Ward 11-York South-Weston) (p. 9). City of Toronto, Heritage Preservation Services. https://www.toronto.ca/legdocs/mmis/2007/ey/bgrd/backgroundfile-2218.pdf

Colavitti, A. M. (2018). Urban heritage management. Springer Berlin Heidelberg.

Cox, A. (2017). Settler Colonialism (pp. 9780190221911-0029) [Data set]. Oxford University Press. https://doi.org/10.1093/obo/9780190221911-0029

Crawley, M. (2019, February 23). Ford government shuts down agency that helps people fight zoning appeals. $C B C$ News. https://www.cbc.ca/news/canada/toronto/doug-ford-closinglocal-planning-appeal-support-centre-1.5029624

Crew. (2020). Toronto's Development Boom Continues Despite COVID-19. KMI Media Ltd. https://www.canadianrealestatemagazine.ca/news/torontos-development-boom-continuesdespite-covid19-330743.aspx

Crutchfield, R., \& Bates, K. A. (2001). Anomie. In Encyclopedia of Sociology (2nd ed., Vol. 1, pp. 164-168). Macmillan Reference USA; Gale eBooks. https://link.gale.com/apps/doc/CX3404400031/GVRL?u=rpu_main\&sid=GVRL\&xid=78 $7 \mathrm{e} 640 \mathrm{f}$

Davies, R., \& City of Toronto-Clerks Office. (2004). Weston Heritage Conservation District Study (Ward 11-York South-Weston) (p. 3). City of Toronto, Heritage Preservation Services. https://www.toronto.ca/legdocs/2004/agendas/council/cc040518/tw4rpt/cl005.pdf 
Delgado, R., \& Stefancic, J. (2017a). Chapter VI-Critiques and Responses to Criticism. In Critical Race Theory: An Introduction (Third edition, pp. 102-112). New York University Press.

Delgado, R., \& Stefancic, J. (2017b). Critical Race Theory: An Introduction (Third edition). New York University Press.

Duperreault, L., \& Midland Park Modernism Alliance. (2020a). About. Midland Park Toronto. http://midlandparktoronto.com/index.html

Duperreault, L., \& Midland Park Modernism Alliance. (2020b). Home. Midland Park Toronto. http://midlandparktoronto.com/index.html

Elliott, M. (2020, August 18). COVID-19 was a 'four-alarm fire' for Toronto's finances. The province's bailout does nothing to douse the flames. https://www.thestar.com/opinion/contributors/2020/08/18/covid-19-was-a-four-alarmfire-for-torontos-finances-the-provinces-bailout-does-nothing-to-douse-the-flames.html

Fainstein, S. S. (2009). Planning and the Just City. In P. Marcuse (Ed.), Searching for the just city: Debates in urban theory and practice (pp. 19-39). Routledge.

Fainstein, S. S., \& DeFilippis, J. (Eds.). (2016). Introduction The Structure and Debates of Planning Theory. In Readings in planning theory (Fourth edition, pp. 1-19). John Wiley \& Sons Inc.

Filion, P., \& Kramer, A. (2011). Metropolitan-scale Planning in Neo-liberal Times: Financial and Political Obstacles to Urban Form Transition. Space and Polity, 15(3), 197-212. https://doi.org/10.1080/13562576.2011.692567

Freeman, B. (2015). The New Urban Agenda: The Greater Toronto and Hamilton Area. Dundurn. 
Gendron, D., \& Heritage Preservation Services. (2005). Agincourt Heritage Conservation District Study Area (Ward 41-Scarborough Rouge River) By Law Council Notes. City of Toronto, City Planning Division.

Goonewardena, K., \& Kipfer, S. (2005). Spaces of Difference: Reflections from Toronto on Multiculturalism, Bourgeois Urbanism and the Possibility of Radical Urban Politics. International Journal of Urban and Regional Research, 29(3), 670-678. https://doi.org/10.1111/j.1468-2427.2005.00611.x

Guo, S., \& Wong, L. L. (2015). Revisiting Multiculturalism in Canada: An Introduction. In Revisiting multiculturalism in Canada: Theories, policies and debates. Boston: Sense Pub. http://site.ebrary.com/id/11125556

Hall, T. (2020). Town planning: The basics. Routledge.

Hebbert, M. (2006). Town Planning Versus Urbanismo. Planning Perspectives, 21(3), 233-251. https://doi.org/10.1080/02665430600731153

Heritage Preservation Services-City of Toronto. (2020). Weston II Heritage Conservation District Study. https://www.toronto.ca/city-government/planning-development/planningstudies-initiatives/weston-phase-2-heritage-conservation-district-plan/

Heritage Toronto. (2019a). Annual Report 2019-Heritage Toronto (p. 28). Heritage Toronto.

Heritage Toronto. (2019b). Changing the Narrative: State of Heritage Report 2019 (p. 36). https://www.heritagetoronto.org/wpcontent/uploads/PDFs/SOH_Reports/State_of_Heritage_Report_2019.pdf Heritage Toronto. (2020). Our History-Heritage Toronto. HeritageToronto.Org. https://www.heritagetoronto.org/our-history/ 
Heritage Toronto, \& Bain, A. (2019, May 30). Heritage Update: Bill 108 Town Hall Message From Our Executive Director [Personal communication].

Hugill, D. (2017). What is a settler-colonial city? Geography Compass, 11(5), e12315. https://doi.org/10.1111/gec3.12315

Hulley, R. (2016, November). The rise of heritage conservation districts. Www.Orea.Com. https://www.orea.com/News-and-Events/Newsletters/EDGENewsletters/2016/November/The-rise-of-heritage-conservation-districts

Huschka, D., \& Mau, S. (2006). Social Anomie and Racial Segregation in South Africa. Social Indicators Research, 76(3), 467-498. https://doi.org/10.1007/s11205-005-2903-x

Indigenous Affairs Office-City of Toronto. (2019, February). Land Acknowledgement. Toronto.Ca. https://www.toronto.ca/city-government/accessibility-humanrights/indigenous-affairs-office/land-acknowledgement/

Jackson, J. (2018). Neoliberalism and urban planning in Toronto: How seasoned planners adjust to their changing circumstances. International Planning Studies, 23(2), 144-162. https://doi.org/10.1080/13563475.2017.1358606

Jonas, A. E. G., McCann, E., \& Thomas, M. E. (2015). Urban geography: A critical introduction. John Wiley \& Sons, Inc.

Kalman, H. (2014). Heritage planning: Principles and process. Routledge. Karlström, A. (2014). Urban Heritage. In C. Smith (Ed.), Encyclopedia of Global Archaeology (pp. 7540-7544). Springer New York. https://doi.org/10.1007/978-1-4419-0465-2_1137 Keenan, E. (2013). Some great idea: Good neighbourhoods, crazy politics and the invention of Toronto (1st ed). Coach House Books. 
Keesmaat, J., \& City of Toronto-Chief Planner and Executive Director. (2015). Attachment 9 A HCD Prioritization Criteria Potential HCD Name: Agincourt (p. 2). City of Toronto.

Keil, R. (2000). Governance Restructuring in Los Angeles and Toronto: Amalgamation or Secession? International Journal of Urban and Regional Research, 24(4), 758-781. https://doi.org/10.1111/1468-2427.00277

Kipfer, S., \& Keil, R. (2002). Toronto Inc? Planning the Competitive City in the New Toronto. Antipode, 34(2), 227-264. https://doi.org/10.1111/1467-8330.00237

Kopun, F. (2020a, March 1). Toronto "living on borrowed time” with its large, aging residential towers (2369508930). The Toronto Star (Online); Torstar Syndication Services, a Division of Toronto Star Newspapers Limited; Global Newsstream. http://ezproxy.lib.ryerson.ca/login?url=https://search.proquest.com/docview/2369508930 ?accountid=13631

Kopun, F. (2020b, June 2). Toronto has picked two sites for new modular housing for the homeless. Here's what they look like. Toronto Star. https://www.thestar.com/news/gta/2020/06/02/toronto-has-picked-two-sites-for-newmodular-housing-for-the-homeless-heres-what-they-look-like.html

Larner, W. (2000). Neo-liberalism: Policy, Ideology, Governmentality. Studies in Political Economy, 63(1), 5-25. https://doi.org/10.1080/19187033.2000.11675231

Leah Hansen. (2018, April 2). The Ontario Municipal Board will soon be no more. Here's what that means for you. CBC News. https://www.cbc.ca/news/canada/ottawa/omb-planningappeal-tribunal-development- 1.4595608

LeBlanc, D. (2005, November 18). Paul Hellyer built my house. The Globe and Mail. Canadian Newsstream. 
http://ezproxy.lib.ryerson.ca/login?url=https://search.proquest.com/docview/383617070? accountid $=13631$

LeBlanc, D. (2006, October 13). An ode to a Canadian icon. The Globe and Mail. Global Newsstream. http://ezproxy.lib.ryerson.ca/login?url=https://search.proquest.com/docview/383497328? accountid $=13631$

LeBlanc, D. (2015, September 10). "McMansion" threat in Modernist Scarborough community ignites activism. The Globe and Mail. https://www.theglobeandmail.com/life/home-andgarden/architecture/d...purs-modernist-scarborough-neighbourhood-toaction/article26313613/

LeGates, R. T., \& Stout, F. (Eds.). (2011). The city reader (5th ed). Routledge. Lintern, G. (2019). City of Toronto Official Plan 2019 (p. 179). City of Toronto.

MacDonald, M. L., Senior Manager Heritage Planning, \& City of Toronto. (2019, December 2). Toronto Preservation Board Orientation.

Manager-Heritage Preservation Services, \& Gendron, D. (2006). Consolidated Clause in Etobicoke York Community Council Report 7, which was considered by City Council . (p. 9). City of Toronto, Planning Division. https://www.toronto.ca/legdocs/mmis/2007/ey/bgrd/backgroundfile-2218.pdf

Marcuse, P. (Ed.). (2009). Searching for the just city: Debates in urban theory and practice. Routledge.

McKeen, A. (2018, March 2). The GTA's population is booming-But not necessarily in the right places (2010196056). The Toronto Star (Online); Torstar Syndication Services, a Division of Toronto Star Newspapers Limited; Global Newsstream. 
http://ezproxy.lib.ryerson.ca/login?url=https://search.proquest.com/docview/2010196056 ?accountid $=13631$

Midland Park Modernism Alliance. (2015a). Midland Park Modernism Newsletter. Midland Park Modernism Alliance. https://us10.campaignarchive.com/?u=4d9bbd7d44b2d89a4c45b4b56\&id $=0 \mathrm{~d} 49 \mathrm{c} 613 \mathrm{~d} 1$

Midland Park Modernism Alliance. (2015b). Midland Park Modernism Newsletter | NOVEMBER 2015. https://us10.campaignarchive.com/?u=4d9bbd7d44b2d89a 4c45b4b56\&id=c7ab023ddb

Midland Park Modernism Alliance. (2016a). Midland Park Modernism Newsletter | Spring 2016 New Variance Application Alert. Midland Park Modernism Alliance. https://us10.campaign-archive.com/?u=4d9bbd7d44b2d89a4c45b4b56\&id=4a7a3a6b3b

Midland Park Modernism Alliance. (2016b). Midland Park Modernism Newsletter | NOV 2016. https://us10.campaign-archive.com/?u=4d9bbd7d44b2d89a4c45b4b56\&id=3b9006764e

Midland Park Modernism Alliance. (2018). Midland Park Modernism Special Announcement | January 2018. Midland Park Modernism Alliance. https://us10.campaignarchive.com/?u=4d9bbd7d44b2d89a4c45b4b56\&id=347fddc620

Ministry of Municipal Affairs and Housing. (2020). Provincial Policy Statement, 2020-Under the Planning Act (p. 57). Goverment of Ontario. ontario.ca/PPS

Monclús, J. F., \& Guàrdia i Bassols, M. (Eds.). (2006). Introduction. In Culture, urbanism and planning (pp. xiii-3). Ashgate.

Moore, A. A. (2013). Planning politics in Toronto: The Ontario Municipal Board and urban development. University of Toronto Press. 
Obad Šćitaroci, M., \& Bojanić Obad Šćitaroci, B. (2019). Heritage Urbanism. Sustainability, 11(9), 1-10. https://doi.org/10.3390/su1 1092669

Obad Šćitaroci, M., Bojanić Obad Šćitaroci, B., \& Mrđa, A. (Eds.). (2019). Cultural Urban Heritage: Development, Learning and Landscape Strategies. Springer International Publishing. https://doi.org/10.1007/978-3-030-10612-6

Office of Economic Policy, \& Ontario Ministry of Finance. (2017). 2016 Census Highlights Ministry of Finance Fact Sheet 9- Ethnic Origin and Visible Minorities. Ontario Government. https://www.fin.gov.on.ca/en/economy/demographics/census/cenhi16-9.pdf

O'Kane, J. (2020, May 25). Sidewalk's end: How the downfall of a Toronto 'smart city' plan began long before COVID-19. The Globe and Mail. Global Newsstream. http://ezproxy.lib.ryerson.ca/login?url=https://search.proquest.com/docview/2406263513 ?accountid=13631

Ontario Heritage Act Register, \& Ontario Heritage Trust. (2019, May). Get the facts Some statistics about heritage conservation districts: https://www.heritagetrust.on.ca/en/pages/tools/conservation-districts/get-the-facts Ontario Heritage Trust. (2020). Heritage Conservation Districts. https://www.heritagetrust.on.ca/en/pages/tools/conservation-districts Ontario Land Tribunals. (2020a). About OLT. https://olt.gov.on.ca/contact/environment-landtribunals-ontario/

Ontario Land Tribunals. (2020b). About the CRB. https://olt.gov.on.ca/tribunals/crb/about-thecrb/

Ontario Land Tribunals. (2020c). Legislation. https://olt.gov.on.ca/tribunals/crb/legislation-andrules/ 
Ontario Ministry of Municipal Affairs and Housing. (2017). Consultation on role of Ontario Municipal Board in Ontario's land use planning system. Goverment of Ontario. https://ero.ontario.ca/notice/012-7196

Ontario Ministry of Tourism, Culture and Sport. (2006). Heritage conservation districts: A guide to district designation under the Ontario Heritage Act. Ministry of Culture.

Pagliaro, J. (2020, May 19). No plan to fix city’s big cash shortfall; Digging out of \$1.5B hole isn't possible without help of other governments, experts say. Toronto Star.

Parks Canada. (2006). Canadian Register of Historic Places Writing Statements of Significance (p. 77). Parks Canada.

Peters, N., \& Kearns, L.-L. (2013). Chapter Four (Re)inscribing Mi'kmaq Presence through Public Petition, Performance and Art. In S. L. T. Ashley (Ed.), Diverse spaces: Identity, Heritage and Community in Canadian Public Culture (pp. 75-100). Cambridge Scholars Publ.

Qadeer, M. A. (2016a). Chapter 2-Multiculturalism: Diversity Rights and the Common Ground. In Multicultural cities: Toronto, New York, and Los Angeles (pp. 20-40). University of Toronto Press.

Qadeer, M. A. (2016b). Chapter 3-Making Multicultural Cities. In Multicultural cities: Toronto, New York, and Los Angeles (pp. 40-56). University of Toronto Press.

Qadeer, M. A. (2016c). Chapter 10-Urban Planning for Cultural Diversity. In Multicultural cities: Toronto, New York, and Los Angeles (pp. 216-245). University of Toronto Press.

Qadeer, M. A. (2016d). Multicultural cities: Toronto, New York, and Los Angeles. University of Toronto Press. 
Radcliffe, S. A. (2017). Geography and indigeneity I: Indigeneity, coloniality and knowledge. Progress in Human Geography, 41(2), 220-229. https://doi.org/10.1177/0309132515612952

Relph, E. (2014). Toronto: Transformations in a city and its region (1st ed). University of Pennsylvania Press.

Ripp, M., \& Rodwell, D. (2016). The governance of urban heritage. The Historic Environment: Policy \& Practice, 7(1), 81-108. https://doi.org/10.1080/17567505.2016.1142699

Rowe, G., \& Frewer, L. J. (2005). A Typology of Public Engagement Mechanisms. Science, Technology, \& Human Values, 30(2), 251-290. https://doi.org/10.1177/0162243904271724

Ruiz-Mallén, I. (2020). Co-production and Resilient Cities to Climate Change. In J. Nared \& D. Bole (Eds.), Participatory Research and Planning in Practice (pp. 1-11). Springer International Publishing. https://doi.org/10.1007/978-3-030-28014-7_1

Sandercock, L. (Ed.). (1998). Making the invisible visible: A multicultural planning history. University of California Press.

Saunders, B., \& Scarborough Community Preservation Panel. (2008, June 3). Agincourt Heritage Conservation District Proposal [Personal communication].

Scarborough Community Heritage Preservation Panel. (2014). Scarborough Community Heritage Preservation Panel (Municipal Heritage Committee) (p. 7). City of Toronto. Scarborough Community Heritage Preservation Panel. (2015). Scarborough Community Heritage Preservation Panel (Municipal Heritage Committee) (p. 6). City of Toronto. Scarborough Community Heritage Preservation Panel. (2016). Scarborough Community Heritage Preservation Panel (Municipal Heritage Committee) (p. 7). City of Toronto. 
Scarborough Community Heritage Preservation Panel. (2017a). Scarborough Community Heritage Preservation Panel (Municipal Heritage Committee) (p. 7). City of Toronto. Scarborough Community Heritage Preservation Panel. (2017b). Minutes of MeetingScarborough Community Heritage Preservation Panel (Municipal Heritage Committee) $T$ (p. 8). City of Toronto.

Scarborough Community Heritage Preservation Panel. (2018a). Scarborough Community Heritage Preservation Panel (Municipal Heritage Committee) (p. 5). City of Toronto. Scarborough Community Heritage Preservation Panel. (2018b). Scarborough Community Heritage Preservation Panel (Municipal Heritage Committee)PB36.16.2 (p. 5). City of Toronto.

Scarborough Community Preservation Board, \& Saunders, R. (2015, July 28). Not exactly as delivered Notes for Preservation Board short talk on Scarborough. https://www.toronto.ca/legdocs/mmis/2015/pb/comm/communicationfile-54161.pdf

Schneider, D. (2017, June 17). Changes to the OMB - meh. OHA $+M$ (Ontario Heritage Act and More).

Schneider, D. (2019a, May 25). What to make of Bill 108 [Educational]. OHA+M (Ontario Heritage Act and More). https://uwaterloo.ca/heritage-resources-centre/blog/post/whatmake-bill-108

Schneider, D. (2019b, November 4). Demolition, "Conserved", and the LPAT, part two. OHA $+M$ (Ontario Heritage Act and More). https://uwaterloo.ca/heritage-resourcescentre/blog/post/demolition-conserved-and-lpat-part-two\#note-9

Schneider, D. (2020a, January 31). Is the LPAT up to the job? OHA+M (Ontario Heritage Act and More). 
Schneider, D. (2020b, March 31). Cultural heritage in the PPS, 2020-Some good tweaks [Educational]. OHA $+M$ (Ontario Heritage Act and More). https://uwaterloo.ca/heritageresources-centre/blog/post/cultural-heritage-pps-2020-some-good-tweaks

Shipley, R., \& Snyder, M. (2013). The role of heritage conservation districts in achieving community economic development goals. International Journal of Heritage Studies, 19(3), 304-321. https://doi.org/10.1080/13527258.2012.660886

Shipley, Robert, Jonas, K., \& Kovacs, J. F. (2011). Heritage Conservation Districts Work: Evidence from the Province of Ontario, Canada. Urban Affairs Review, 47(5), 611-641. https://doi.org/10.1177/1078087411400559

Shipley, Robert, \& Kovacs, J. (2005). Principles for the Governance of the Heritage Conservation Sector in Canada: Lessons from International Experience (p. 36). The Heritage Resources Centre University of Waterloo.

Shipley, Robert, \& Kovacs, J. F. (2008). Good governance principles for the cultural heritage sector: Lessons from international experience. Corporate Governance: The International Journal of Business in Society, 8(2), 214-228. https://doi.org/10.1108/14720700810863823

Shum, D. (2018, October 23). John Tory wins 2nd term as mayor of Toronto. GLOBAL NEWS. https://globalnews.ca/news/4582197/john-tory-wins-mayor-toronto/

Spurr, B. (2020a, March 30). Major delays expected on transit projects; Health precautions, supply chain disruptions among issues, expert says. Toronto Star, Web.

Spurr, B. (2020b, May 25). City proposes rapid bike network expansion with new lanes on Bloor, University, Danforth. The Toronto Star (Toronto, Ontario), NA. Gale OneFile: CPI.Q. 
The Canadian Press. (2020, March 26). Supreme Court agrees to hear City of Toronto appeal of Ontario's decision to cut council. CBC News. https:/www.cbc.ca/news/canada/toronto/toronto-city-council-ford-supreme-courtcanada-1.5510673

Thobani, S. (2014). Chapter 11- Race, Sovereignty, and Empire: Theorizing the Camp, Theorizing Postmodernity. In A. B. Bakan \& E. Dua (Eds.), Theorizing anti-racism: Linkages in Marxism and critical race theories. Univ. of Toronto Press.

Torontoist. (2015, November 12). Heritage Conservation Designation Points to a Tale of Two Cities. Torontoist. https://torontoist.com/2015/11/heritage-conservation-designationpoints-to-a-tale-of-two-cities/

Tribunals Ontario. (2020). About LPAT [Government]. Tribunals Ontario Environment \& Land Division. https:/elto.gov.on.ca/tribunals/lpat/about-lpat/

Viswanathan, L. (2009). "Postcolonial Planning” and Ethno-Racial Diversity in Toronto: Locating Equity in a Contemporary Planning Context. Canadian Journal of Urban Research, 18(1), 162-182.

Walker, R., \& Belanger, Y. (2013). Aboriginality and Planning in Canada's Large Prairie Cities. In Reclaiming indigenous planning (p. 24).

Welch LLP - Chartered Professional Accountants. (2019). FINANCIAL STATEMENTS For HERITAGE TORONTO For the year ended. Welch LLP. https:/www.heritagetoronto.org/wpcontent/uploads/PDFs/Executed_Financial_Statements/Heritage-Toronto-fs19.pdf 
What's changing? The Provincial Policy Statement, 2020. (2020, March 9). Dentons. https://www.dentons.com/en/insights/articles/2020/march/9/whats-changing-theprovincial-policy-statement-2020

Wheeler, S. M., \& Beatley, T. (2014). The sustainable urban development reader. Routledge, 2014. http://site.ebrary.com/id/10951230

White, R. (2007). The Growth Plan for the Greater Golden Horseshoe in Historical Perspective. 54.

Williamson, R. F., Robertson, D. A., \& Hughes, S. (2017). Archaeological Resource Management in Toronto: Planning, Preservation, and Interpretation. In S. Baugher, D. R. Appler, \& W. Moss (Eds.), Urban Archaeology, Municipal Government and Local Planning: Preserving Heritage within the Commonwealth of Nations and the United States (pp. 69-89). Springer International Publishing. https://doi.org/10.1007/978-3-319$55490-7$ _5

Wong-Tam, K., Matlow, J., \& Perks, G. (2019, May 27). Facebook Event: Town Hall on Bill 108: The OMB is Back [Social Media]. Facebook. https://www.facebook.com/events/309554903273831/ 